\title{
ANTI-APOPTOTIC AND ANTIOXIDANT DEFENSES IN THE FREEZE TOLERANT WOOD FROG, RANA SYLVATICA
}

By

Jun Du

B.Sc. Northeast Normal University (China), 1992

A Thesis submitted to the Faculty of Graduate Studies and Research

in partial fulfillment of the requirements for the degree of

\author{
Master of Science \\ Department of Chemistry
}

Carleton University

Ottawa, ON, Canada

(C) Copyright

2005, Jun Du 


$\begin{array}{ll}\begin{array}{l}\text { Library and } \\ \text { Archives Canada }\end{array} & \begin{array}{l}\text { Bibliothèque et } \\ \text { Archives Canada }\end{array} \\ \begin{array}{l}\text { Published Heritage } \\ \text { Branch }\end{array} & \begin{array}{l}\text { Direction du } \\ \text { Patrimoine de l'édition }\end{array} \\ \begin{array}{l}\text { 395 Wellington Street } \\ \text { Ottawa ON K1A ON4 }\end{array} & \begin{array}{l}\text { 395, rue Wellington } \\ \text { Ottawa ON K1A ON4 } \\ \text { Canada }\end{array}\end{array}$

Your file Votre référence

ISBN: 0-494-10135-0

Ourfile Notre référence

ISBN: 0-494-10135-0

NOTICE:

The author has granted a nonexclusive license allowing Library and Archives Canada to reproduce, publish, archive, preserve, conserve, communicate to the public by telecommunication or on the Internet, loan, distribute and sell theses worldwide, for commercial or noncommercial purposes, in microform, paper, electronic and/or any other formats.

The author retains copyright ownership and moral rights in this thesis. Neither the thesis nor substantial extracts from it may be printed or otherwise reproduced without the author's permission.
AVIS:

L'auteur a accordé une licence non exclusive permettant à la Bibliothèque et Archives Canada de reproduire, publier, archiver, sauvegarder, conserver, transmettre au public par télécommunication ou par l'Internet, prêter, distribuer et vendre des thèses partout dans le monde, à des fins commerciales ou autres, sur support microforme, papier, électronique et/ou autres formats.

L'auteur conserve la propriété du droit d'auteur et des droits moraux qui protège cette thèse. $\mathrm{Ni}$ la thèse ni des extraits substantiels de celle-ci ne doivent être imprimés ou autrement reproduits sans son autorisation.
In compliance with the Canadian

Privacy Act some supporting forms may have been removed from this thesis.

While these forms may be included in the document page count, their removal does not represent any loss of content from the thesis.
Conformément à la loi canadienne sur la protection de la vie privée, quelques formulaires secondaires ont été enlevés de cette thèse.

Bien que ces formulaires aient inclus dans la pagination, il n'y aura aucun contenu manquant.

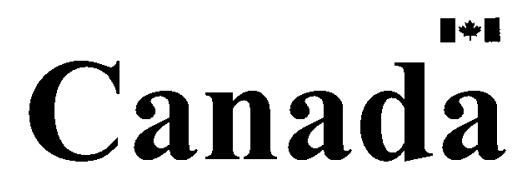




\begin{abstract}
Multiple biochemical adaptations support natural freeze tolerance by wood frogs, Rana sylvatica. The present research explored the role of anti-apoptotic and antioxidant defenses in organ survival of freeze/thaw stresses using PCR and Western blotting to analyze the expression of selected genes and proteins. The STAT family of transcription factors mediate both pro- and anti-apoptotic gene responses. Elevated amounts of phosphorylated (active) Stat5 (Tyr694) and/or phospho-Stat3 (Ser727) in selected frog organs during freeze/thaw suggest activation of anti-apoptotic defenses to help organs recover from metabolic insults caused by freezing. However, levels of phospho-Stat1 (Tyr701), a pro-apoptotic signal, also rose in kidney and muscle during thawing. Increased amounts of anti-apoptotic proteins including $\mathrm{Bcl}-2$ and phospho- $\mathrm{Bcl}-2$ (Ser70) in liver and skeletal muscle and Bcl-xL (and phospho-Bcl-2) in kidney could help counteract freeze-induced apoptotic signals that were evidenced by higher levels of Bad protein (liver, muscle, kidney) and phospho-Bad (Ser112) (kidney) and enhanced DNA laddering. Antioxidant defense via glutathione $S$-transferase (GST) was evaluated by analyzing the expression of GST isozymes. GST Pi protein rose in four organs during freeze/thaw and GST Pi mRNA was freeze up-regulated in liver. GST M1/2, M5, A3 and A5 were freeze- or thaw- responsive in selected organs. Freeze-induced changes in the transcription factors, $\mathrm{Nrf} 2$ and $\mathrm{MafG}$, and elevated $\mathrm{MafG}$ in the nucleus suggest that these regulate the freeze up-regulation of antioxidant enzymes by targeting the antioxidant response element of genes. Both anti-apoptotic and antioxidant defenses are important aspects of natural freezing survival.
\end{abstract}




\section{Acknowledgements}

First and foremost, I would like to thank Dr. Kenneth B. Storey who accepted me to his Lab, whose teaching, guidance, and support have provided a solid foundation for me to pursue scientific work in North America. In Storey Lab, I gradually learn what SCIENCE is; I wish I should have been this Lab several years before. I also sincerely thank Jan Storey, for her perfect editing, insightful suggestions and comments for my thesis. Without her consistent help, my thesis work would have taken much longer, and I am really grateful to her help.

I also thank Dr. Bill Willmore for his support and help during my two-year study in Carleton University.

Many thanks also go to my lab colleagues, Pier, Mamady, Chris R, Julie, Keqin, Li, Khalil, Ashley, Joann, Jeremy, Jiayun and Chris D. Thanks for their help, encouragement and fun.

Finally, I wish to thank my family for their support and understanding. A special thanks goes to my cute daughter, Lucy (Dongman), her last word "hard working" at every long distance call pushes me to work hard. 


\section{Table of Contents}

Title Page $\quad$ i

Acceptance Page ii

$\begin{array}{lll}\text { Abstract } & \text { iii }\end{array}$

Acknowledgments

Table of Contents $\quad \mathrm{v}$

List of Abbreviations vi-vii

List of Tables viii

List of Figures $\quad$ ix-xi

Chapter 1 General Introduction $1-11$

Chapter 2 Anti-Apoptotic Defense in Wood Frogs $\quad 12-49$

Chapter 3 Glutathione $S$-Transferases and Antioxidant Defense $\quad$ 50-88

Chapter 4 General Discussion $\quad$ 89-97

$\begin{array}{ll}\text { References } & 98-108\end{array}$ 


\section{List of Abbreviations}

\begin{tabular}{|c|c|}
\hline ADP & adenosine diphosphate \\
\hline ATP & denosine triphosphate \\
\hline ARE & antioxidant response element \\
\hline $\mathrm{Bad}$ & Bcl-2-associated death protein \\
\hline $\mathrm{Bcl}-2$ & B-cell leukemia/lymphoma 2 \\
\hline $\mathrm{Bcl-xL}$ & $B$ cell leukemia/lymphoma $x L$ \\
\hline BLAST & Basic Local Alignment Search Tool \\
\hline cDNA & complementary DNA \\
\hline DEPC & diethylpyrocarbonate \\
\hline $\mathrm{ECL}$ & enhanced chemiluminescence \\
\hline EDTA & ethylenediamine tetraacetic acid \\
\hline EMSA & Electrophoretic Mobility Shift Assay \\
\hline GST & glutathione S-transferase \\
\hline $\mathrm{EtBr}$ & ethidium bromide \\
\hline HEPES & N-(2-hydroxyethyl) piperazine-N'- (2-ethanesulfonic acid) \\
\hline HO1 & heme oxygenase 1 \\
\hline JAKs & anus family tyrosine kinases \\
\hline $\mathrm{kb}$ & kilobase \\
\hline $\mathrm{kDa}$ & kilo Dalton \\
\hline Keap1 & Kelch-like ECH-associated protein 1 \\
\hline MafG & v-maf musculoaponeurotic fibrosarcoma (avian) oncogene family, \\
\hline
\end{tabular}


MOPS

2- (N- morpholine) proanesulfonic acid

mRNA

NQO1

Nrf2

PAGE

PCR

PMSF

PVDF

RACE

ROS

RT

RT-PCR

SDS

SOD

STATs

TAE

TEMED

UGT messenger RNA

NAD(P)H: quinone oxidoreductase-1

nuclear factor-erythroid 2 related factor -2

polyacrylamide gel electrophoresis

polymerase chain reaction

phenylmethanesulfonyl fluoride

polyvinylidine fluoride

rapid amplification of cDNA ends

reactive oxygen species

room temperature $\left(\sim 20^{\circ} \mathrm{C}\right)$

reverse-transcriptase polymerase chain reaction

sodium dodecyl sulfate

superoxide dismutase

Signal Transducers and Activators of Transcription

Tris-Acetate-ethylenediamine tetraacetic acid buffer

$\mathrm{N}, \mathrm{N}, \mathrm{N}^{\prime}, \mathrm{N}^{\prime}$-tetramethylethylenediamine

uridine-diphosphoglucuronosyltransferase 


\section{List of Tables}

Table Page

Table 2.1 Experimental Conditions of western blotting 25

Table 2.2 Antibodies used in western blotting 26

Table 3.1 Experimental Conditions of Western Blotting 61

Table 3.2 Antibodies Used in Western Blotting 62 
Figure

\section{List of Figures}

1.1 The North American distribution of the wood frogs, Rana sylvatica. 11

$\begin{array}{lll}2.1 & \text { The JAK-STAT signal transduction pathways } & 17\end{array}$

$\begin{array}{lll}2.2 & \text { Bcl-2 Family Signaling Pathways } & 18\end{array}$

2.3 Western blot analysis of phospho-Stat5 (Tyr694) protein content in liver, muscle, kidney and skin of wood frogs from three conditions: control, frozen and thawed recovery

2.4 Western blots showing the effects of anoxia and dehydration stresses on phospho-Stat5 (Tyr694) content in wood frog tissues.

2.5 Western blots showing phospho-Stat1 (Tyr701) and phospho-Stat3 (Ser727) protein contents in tissues of control, frozen and thawed frogs. 34

2.6 Western blots showing Bcl-2 and phospho-Bcl-2 (Ser70) protein contents in wood frog tissues of control, frozen and recovery samples.

2.7 Western blots showing Bcl-xL protein content in tissues of liver, muscle and kidney from control, frozen and recovery samples.

2.8 Western blots showing Bad and phospho-Bad (Ser112) protein contents in liver, muscle and kidney from control, frozen and thawed recovery frogs. 37

2.9 Analysis of DNA laddering in wood frog liver comparing control frogs. 38

3.0 Mechanism of ARE/Nrf2 pathway $\quad 54$

3.1 Partial nucleotide and deduced amino acid sequence of the wood frog GST Pi gene product that was amplified from frog liver cDNA.

3.2 Wood frog GST Pi partial nucleotide sequence aligned with African 
clawed frog, house mouse and human nucleotide sequences and Homology tree of partial wood frog, clawed frog, house mouse and human GST Pi nucleotide sequences.

3.3 Wood frog GST Pi partial amino acid sequence aligned with clawed frog, house mouse and human GST Pi amino acid sequences. (B) Homology tree of partial wood frog, clawed frog, house mouse and human GST Pi amino acid sequences.

3.4 Western blots analysis of GST Pi protein content in brain, gut, liver, kidney, heart and skeletal muscle of wood frogs from three conditions: control, frozen and thawed recovery.

3.5 Analysis of GST Pi mRNA transcript levels in frog tissues by RT-PCR. 74

3.6 Western blot analysis of GST M1/2 protein content in brain, gut, liver, muscle, kidney and skin of wood frogs from three conditions: control, frozen and thawed recovery.

3.7 Western blot analysis of GSTA5 protein content in liver and muscle of wood frogs from three conditions: control, frozen and thawed recovery. 76

3.8 Western blot showing GST M5 and GST A3 protein contents in control, frozen and thawed wood frogs.

3.9 Western blots showing $\mathrm{Nrf2}(\sim 40 \mathrm{kDa})$ protein contents in brain, gut, skin, muscle and liver from control, frozen and thawed frogs.

3.10 Western blots showing Nrf2 $(\sim 82 \mathrm{kDa})$ protein contents in brain, gut, skin, muscle and liver from control, frozen and thawed frogs.

3.11 Western blots showing MafG protein contents in tissues of control, 
frozen and thawed wood frogs.

3.12 Analysis of Nrf2 and MafG protein distribution between cytoplasmic and nuclear fractions of muscle in control, frozen and thawed recovery wood frogs. 


\section{Chapter 1}

\section{General Introduction}


The wood frog, Rana sylvatica, is widely accepted as a model animal for studying the mechanisms of freezing survival by vertebrates. Much of the research on the metabolic and gene expression adaptations that underlie natural freeze tolerance has been done in our laboratory. Studies presented in this thesis continue the exploration of the biochemical adaptations and molecular mechanisms that evolved to sustain freezing survival. In particular, I focus on antioxidant and anti-apoptotic defense mechanisms.

\subsection{Natural Stress Survival}

All living organisms are challenged by multiple stresses in their natural environments, including variation in the availability of oxygen, food and water and changes in temperature, salinity, atmospheric pressure, radiation, and exposure to toxins. Beyond a certain range of variation in these factors, organisms experience stress that can be damaging or even cause death. Different species have evolved to adapt to the challenges presented by the natural environments in which they live. Temperature change is probably the most common environmental stress experienced by all living organisms, and the potential for freezing at temperatures below $0^{\circ} \mathrm{C}$ is one of the most severe environmental threats that living organisms face. Wood frogs hibernate on the forest floor covered by layers of leaf litter and snow that provide substantial insulation from the coldest winter air temperature above the snowpack. However, despite this, temperatures under the snowpack at ground level often drop to $-5^{\circ} \mathrm{C}$ or lower in midwinter. Wood frogs are highly susceptible to inoculative freezing by contact with environmental ice and so frequently spend a considerable part of the winter frozen. Laboratory tests have demonstrated that wood frogs can endure the conversion 65 to $70 \%$ of total body water 
into extracellular ice and can sustain several weeks of freezing at $-2.5^{\circ} \mathrm{C}$, fully recovering all vital functions within $24 \mathrm{~h}$ after thawing (Storey and Storey, 1993). Freezing places several stresses on animals including (a) the potential for physical damage to tissues and blood vessels by ice crystals, (b) ischemia caused by the freezing of blood plasma, (c) dehydration of cells due to water loss into extracellular ice masses, and (d) the interruption of various vital functions including heart beat, breathing, muscle movement, and brain activity. Freeze tolerant organisms need mechanisms to prevent or reverse damage caused by these stresses. For example, animals need adaptations to deal with long term ischemia caused by freezing that halts the delivery of oxygen and nutrients to tissues, the removal of wastes, and interorgan communication via hormones and other signals (Storey and Storey, 2004). Furthermore, during recovery after freezing, frogs have to deal with additional stress including assault by reactive oxygen species which oxygen is rapidly reintroduced into their systems. This is functionally analogous to the reperfusion stress seen in mammals recovering from stroke or heart attack. Therefore, wood frogs also need strong antioxidant defense mechanisms.

Behavioral, physiological, and biochemical adaptations can help organisms to overcome stresses. Biochemical studies have demonstrated that the adaptations of cellular metabolism to environmental stress can involve a number of different mechanisms including changes in metabolic rate, and changes to the amounts, activities or subcellular distribution of enzymes and functional proteins ( $\mathrm{Wu}, 1999)$. Cellular metabolism is made up of hundreds of different biochemical pathways and functions that call upon thousands of different enzymes, and functional and structural proteins, as well as their substrates and cofactors and their interactions with numerous physical parameters (e.g. pH, 
temperature, ionic strength). When cells and organisms respond to a variety of stresses, the metabolic adjustments can often be accomplished by regulating the action of selected enzymes and other proteins. These can be controlled by a variety of regulatory mechanisms, including fine controls such as the availability of enzyme substrates and cofactors, the actions of allosteric effectors, changes in physical parameters, covalent modification of proteins (e.g. protein phosphorylation or dephosphorylation), and coarse controls on the amounts of proteins through regulation of the rates of protein synthesis and degradation. In the present thesis, I concentrate mainly on changes in the amounts of some enzymes and proteins and gene expression.

\subsection{Adaptations for freeze tolerance}

Wood frogs, $R$. sylvatica, are distributed across most of Canada, the northeastern United States and Alaska (Figure. 1.1) (Behler and King, 1979). This species is one of just a few cold-blooded vertebrates that can survive whole body freezing. Rubinsky et al. (1994) have illustrated the process of ice permeation through wood frog organs using proton magnetic resonance imaging. Ice formation begins at peripheral sites on the frog's skin and then spreads inward through the body. As noted above, freezing can cause many forms of damage to organisms. Intracellular freezing is lethal to all organisms but a variety of poikilothermic vertebrates and invertebrates have developed the ability to endure ice formation in extracellular spaces (Storey and Storey, 2004). The fact that wood frogs can survive freezing induced scientists to explore this natural amazing species. Studies of vertebrate freeze tolerance can also provide insights to the techniques and approaches that can be applied for the development of organ cryopreservation 
technology as an aid to transplant medicine.

The majority of freeze tolerant species accumulate high concentrations of low molecular weight carbohydrates (sugars or polyhydric alcohols) that act as cryoprotectants. In general, cryoprotectants have multiple functions including (a) limiting the extent of cell volume reduction during freezing due to the colligative action of high intracellular concentrations of cryoprotectants, and (b) stabilizing cellular proteins and membranes against low temperature and dehydration stresses (Mazur, 1984). The cryoprotectant in wood frogs is glucose, the normal blood sugar of vertebrates (Storey and Storey, 1984). Within five minutes after the initiation of freezing at the skin surface, the synthesis of glucose from liver glycogen begins and the sugar is rapidly distributed throughout the body (Storey and Storey, 1984). During freezing, the average blood concentration of glucose can rise to $185 \mu \mathrm{mol} / \mathrm{ml}$ from control level of $\sim 3-5 \mu \mathrm{mol} / \mathrm{ml}$. Organ levels of glucose can reach as high as $390 \mu \mathrm{mol} / \mathrm{g}$ wet weight in liver, about 150 $200 \mu \mathrm{mol} / \mathrm{g}$ wet weight in heart and kidney, and about $30 \mu \mathrm{mol} / \mathrm{g}$ wet weight in leg muscle (Storey and Storey, 1984). Due to their high glucose content, liver and heart are the last organs to freeze and also first to thaw when frogs rewarms (Rubinsky et al., 1994). As a consequence of early thawing, the heart can provide a rapid restoration of blood to each organ as soon as it thaws. On thawing, glucose is restored as liver glycogen, where it is available to be used again in the next freezing bout (Storey, 1987a).

Apart from the cryoprotection offered by glucose, recent studies in our laboratory have shown that the freeze-responsive up-regulation of a variety of genes enhances the levels of multiple proteins to support freeze tolerance (Cai and Storey, 1997a, b; Cai et al., 1997, Wu, 1999; McNally 2002; De Croos, 2003; Li, 2004). Each gene/protein 
addresses a different functional need for freezing survival and is often expressed in a tissue-specific manner. For example, up-regulation the mitochondrial ADP/ATP translocase may help maintain the functional integrity of mitochondria under stress (Cai and Storey, 1997b). Up-regulation of heat shock proteins as chaperones may stabilize proteins against multiple stresses in cells during freezing (Li, 2004). Furthermore, three unknown novel genes (FR10, FR47, Li16) have been isolated whose protein functions have yet to be determined.

\subsection{Antioxidant defenses during freeze/thaw}

All organisms maintain antioxidant defenses, both enzymes and metabolites, that deal with the continual assault to cellular metabolism by reactive oxygen species (ROS) such as superoxide, hydrogen peroxide, hydroxyl radicals and peroxynitrite (Storey and Storey, 2004). Studies in mammalian systems have show that oxidative stress is greatest during the reperfusion phase after an ischemic insult because reoxygenation results in a burst of oxyradical production that can temporarily overwhelm the antioxidant defenses of organs. ROS can cause serious damage to cellular lipids, proteins, and DNA. Animals that undergo natural cycles of oxygen deprivation (anoxia, hypoxia) or ischemic episodes (such as freezing), typically use one of two strategies to upgrade their antioxidant defenses to minimize damage by oxidative stress associated with freeze-thaw (HermesLima et al., 2001). The first is the maintenance of high constitutive activities of antioxidant enzymes in frog organs (Storey and Storey, 2004). Joanisse et al. (1996) demonstrated that the activities of the main antioxidant enzymes were substantially higher in some wood frog organs than organs of leopard frogs (that hibernate 
underwater), including glutathione S-transferase, glutathione peroxidase, glutathione reductase, and superoxide dismutase. The second principle of antioxidant defense in wood frogs is selective changes to the activities of some enzymes in direct response to freezing (Storey and Storey, 2004). For example, selenium-dependent glutathione peroxidase activity increased $\sim 2$-fold in heart, kidney, and skeletal muscle (Joanisse and Storey, 1996). These selective changes to antioxidant defenses might also help to minimize the potential for oxidative damage arising due to extremely high glucose levels. Free glucose is prone to autooxidation in the presence of transition metals (iron, copper) to form protein-reactive dicarbonyl compounds and hydrogen peroxide which leads to formation of highly reactive hydroxyl ions; glycated proteins are also effective free radical generators (Hunt et al., 1993). Based on previous studies in our laboratory, the role of antioxidant defenses in freezing survival will be further explored in this thesis via analyses of antioxidant enzyme responses at both protein expression and gene transcriptional levels.

\subsection{Anti-apoptotic defenses during freeze/thaw}

Apoptosis is an actively regulated process of cell death that is necessary for the proper control of tissue growth and differentiation. Apoptosis was originally described by Kerr et al. (1972) as an event characterized by plasma membrane blebbing, cell shrinkage, chromatin condensation, and degradation of DNA. Apoptotic cell death is a tightly controlled process, and the cellular pathways that regulate apoptosis have been well conserved in multicellular organisms from simple to complex animals (Takahashi et al., 2004). Two major pathways, extrinsic and intrinsic, for induction of apoptosis have 
been identified in recent years (Fiers et al., 1999; Finucane, et al., 1999; Jianrong et al., 1999; Nomura et al., 1999). The extrinsic pathway is represented by tumor necrosis factor $(\mathrm{TNF}-\alpha)$ family receptors that contain protein interaction modules known as death domains in their cytosolic regions. The intrinsic pathway of apoptosis involves mitochondria. A variety of key events in apoptosis focus on mitochondria, such as changes in electron transport, release of cytochrome $C$, and altered mitochondrial oxidation-reduction state (Takahashi et al., 2004). Finucane et al. (1999) also demonstrated that induction of downstream caspase activity is dependent on dATP and cytochrome $C$ release from mitochondria, and can be inhibited by anti-apoptotic Bcl-2 family members. These two pathways can each stimulate apoptosis independent of one another but cross-talk between them also occurs. Nomura et al. (1999) proved that TNF- $\alpha$ treatment of cells could induce caspase-mediated cleavage of cytosolic inactive BID to a smaller active BID protein that translocated to the mitochondria, integrated into the mitochondrial membrane and caused cytochrome $C$ release.

Many studies in mammalian systems have shown that oxidative stress and ischemia can trigger or accelerate apoptosis (Saikumar et al., 2003; Kumar and Jugdutt, 2003; Efting et al., 2004; Zhao 2004; Love 2003). For example, myocardial apoptosis is primarily triggered during reperfusion by increased levels of ROS, which results in enhanced release of pro-apoptotic genes from mitochondria (Zhao, 2004). Apoptosis during myocardial ischemia/reperfusion has been documented in different heart diseases (Maclellan et al., 1997) where it may play a significant role in the development of heart failure (Haunstetter and Izumo, 1998). Apoptosis also can be induced during ischaemia in brain (Love, 2003). 
As mentioned before, wood frogs have to endure a variety of stresses including cold stress, ischemia stress, oxidative stress, and osmotic/dehydration stress during freeze/thaw. Because freezing is an anoxia/ischemia stress (Storey and Storey, 2004), the potential exists for apoptosis to be triggered in wood frog organs during either freezing or thawing. Previous studies in our laboratory implicated several anti-apoptotic proteins (AP-2 $\alpha$, BAX-inhibitor, p53) in an anti-apoptotic mechanism in wood frog liver (De Croos, 2003). In the present thesis, I further explore the concept of anti-apoptosis in selected organs of wood frogs.

\subsection{Hypothesis and Experimental outline}

\section{Hypotheses:}

1. Freezing survival involves the up-regulation of selected antioxidant enzymes and enhanced levels of signal transduction proteins involved in controlling antioxidant gene expression.

2. Freezing survival involves mechanisms of anti-apoptosis that help cells to survive/recover after stresses that could otherwise trigger cell death.

To test these hypotheses, I carried out multiple techniques including western blotting, relative quantitative PCR, and DNA laddering to identify genes and proteins related to these two defense mechanisms in frog organs.

Anti-apoptotic defense in wood frogs is reported in Chapter 2. Proteins involved in two pathways were investigated: (a) the JAK-STAT signal transduction pathway, and (b) the Bcl-2 family of anti-apoptotic proteins. The proteins studied included the Signal Transducers and Activators of Transcription (STATs) family and B-cell 
leukemia/lymphoma 2 protein $(\mathrm{Bcl}-2)$ family.

Antioxidant defense in wood frogs is investigated in Chapter 3. Glutathione Stransferases (GSTs) were studied at both transcriptional level and translational level, with a particular emphasis on the GST pi isoform. GSTs are a major group of detoxification enzymes. They are found in all eukaryotic species and include both cytosolic and membrane-bound GST isozymes; the most abundant mammalian GST forms being the class alpha, mu, and pi enzymes (Hayes and Pulford, 1995). The Nrf2/MafG/ARE signal transduction pathway was also investigated to assess its possible role in controlling freeze/thaw related changes in antioxidant enzymes.

This thesis represents the first analysis of the roles of STATs and NRF in the adaptational biochemistry of frogs. The study of wood frogs with their unusual ability to survive freezing provides a special approach to human problems. The wood frog as a model system has the potential to reveal principles and mechanisms that might be applied in a number of fields. For example, the mechanisms of organ cryoprotection that occur naturally in frogs may be applied in the development of strategies for mammalian organ cryopreservation. The mechanisms used by frogs to avoid damage by the extremely high glucose levels accumulated during freezing could also have applications in diabetes research. 


\section{Figure 1.1}

The North American distribution of the wood frogs, Rana sylvatica. Copied from Northern Prairie Wildlife Research Center Homepage, 2002. 


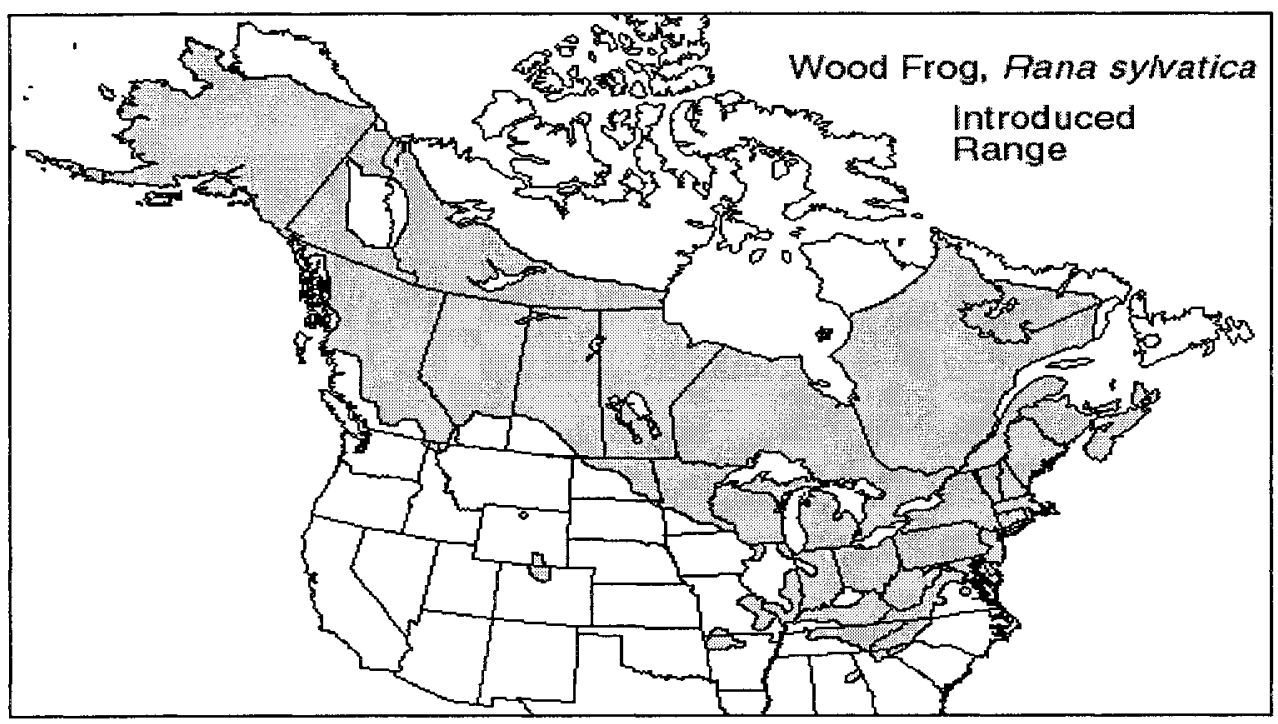




\section{Chapter 2}

\section{Anti-Apoptotic Defense in Wood Frogs}




\subsection{Introduction}

Apoptosis, or programmed cell death, is an active process in which individual cells, responding to internal and/or external cues, commit suicide (Chang et al., 1997). Since its discovery by Kerr et al. (1972) apoptosis has been characterized by several distinct morphological features or hallmarks including chromatin condensation, cell shrinkage, DNA cleavage, membrane blebbing, and fragmentation of the cell into membrane-bound apoptotic bodies (Figueroa et al., 2001). The process of apoptosis can be divided into four phases: initiation, signaling, effectors and degradation. During the initiation phase, cells receive apoptosis-triggering stimuli; numerous signaling pathways are triggered by internal or external stimuli. These stimulus-specific pathways, known as the signaling pathway, converge into a few common pathways, which characterize the effector phase (Zamzami et al., 1998). Then the cell enters the degradation phase, which is characterized by a number of morphological and biochemical changes, including DNA fragmentation, exposure of phosphatidylserine in the plasma membrane, and degradation of multiple structural and repair proteins in the cytosol, cytoskeleton, and nucleus (Zamzami et al., 1998). Environmental stresses including oxidative stress and ischaemia can also initiate apoptosis in a cell by degrading DNA, releasing cytochrome $C$ from mitochondria, ultimately leading to cellular damage and organ dysfunction.

During winter hibernation wood frogs, R. sylvatica, can experience the freezing of $50-70 \%$ of total body water. Ice formation is potentially injurious; as discussed in Chapter 1 freeze-induced injuries to nontolerant cells can include physical damage from ice crystals, dehydration due to water loss into extracellular ice masses, and ischaemia due to plasma freezing (Storey and Storey, 2004). Nontolerant organisms experiencing 
these stresses would experience substantial injuries to tissues, causing cells to initiate apoptosis. Studies have shown that wood frogs have a variety of adaptations that defend cells during freezing and thawing including the production of high concentrations of cryoprotectant, good anoxia/ischemia resistance, antioxidant defenses, and differential gene expression (Storey and Storey, 2004). Another potential area of adaptation for freezing survival is defense against apoptosis - mechanisms that could interrupt or suppress the triggering of apoptosis and thereby help to give wood frog cells the chance to endure/resist the stresses associated with freezing without triggering cell death.

I hypothesized that the changes in the amount or activity state of proteins associated with apoptosis and/or anti-apoptosis could produce a net effect that protects wood frog cells from undergoing apoptosis in response to freeze/thaw. The current chapter quantifies the levels of several proteins that have anti-apoptosis functions in mammalian cells and assesses changes in their relative activity during freezing by examining their phosphorylation state. The proteins chosen for study were the Signal Transducers and Activators of Transcription (STATs), B-cell leukemia/lymphoma 2 protein (Bcl-2); B cell leukemia/lymphoma $\mathrm{xL}(\mathrm{Bcl}-\mathrm{xL})$ protein, and $\mathrm{Bcl}-2$-associated death protein (Bad). Relative levels of phospho-STATs, Bcl-2, phospho-Bcl-2; Bcl-xL; Bad and phospho-Bad were quantified in selected organs tissues of wood frogs via Western blotting.

STATs are transcription factors that are important in mediating the effects of numerous cytokines, polypeptide growth factors, hormones, and oncoproteins (Battle et al., 2002). By modulating the expression of target genes, STAT transcription factors regulate a broad range of biological processes including cell growth, differentiation, 
survival, and development (Battle et al., 2002). For these frogs, little is known about development, especially with respect to freeze tolerance. Seven STAT genes have been identified in mammalian cells (STATs $1,2,3,4,5 \mathrm{~A}, 5 \mathrm{~B}, 6$ ), and the corresponding gene products share a high degree of structural similarity. Each STAT protein has a DNA binding domain, a src-homology 2 (SH2) domain necessary for homo- or heterodimerization, and a conserved tyrosine residue that can be phosphorylated by Janus protein kinases (JAKs) and other tyrosine kinases. STAT proteins also contain a conserved serine residue, which upon phosphorylation enhances transcriptional activity (Battle et al., 2002). Phosphorylated STATs form homo- or hetero-dimers, enter the nucleus and, working co-ordinately with other transcriptional co-activators or transcription factors, lead to increased transcriptional initiation (Figure 2.1) (Bromberg et al., 2000).

Persistent signaling of specific STATs, in particular STAT3 and STAT5, have been shown to directly contribute to oncogenesis by stimulating cell proliferation and preventing apoptosis. STATs participate in oncogenesis through up-regulation of genes encoding apoptosis inhibitors and cell cycle regulators, such as Bcl-xL, Mcl-1, cyclins D1/D2, and c-Myc (Buttner et al., 2002). STATs may actually have dual functions in apoptosis. A number of recent studies have defined both pro-apoptotic and anti-apoptotic signaling pathways mediated by STAT transcription factors (Battle et al., 2002).

Some proteins in the Bcl-2 family are frequently among the downstream proteins regulated by STAT transcription factors (e.g. Bcl-xL, Pim-1). Proteins in the Bcl-2 family may have either anti-apoptotic (e.g. Bcl-xL, Bcl-2, MCL-1, etc.) or pro-apoptotic functions (e.g. Bad, Bax, Bak, etc.). The ratio between these two subsets helps to 
determine, in part, the susceptibility of a cell to a death signal (Gross et al. 1999). For example, over-expression of $\mathrm{Bcl}-2$ and $\mathrm{Bcl}-\mathrm{xL}$ can limit apoptosis and enhance survivability of mammalian cells (Mastrangelo et al., 2000, Singh et al., 1996). Phosphorylation of Bcl-2 at Ser 70 may be required for full and potent anti-apoptosis function (Deng et al. 2001, Ruvolo et al. 2002).

The pro-apoptotic protein Bad normally resides in the cytosol but can translocate to mitochondria following death signaling. As an important member of the $\mathrm{Bcl}-2$ protein family, Bad plays a critical role in apoptosis. A prevailing hypothesis is that Bad promotes apoptosis by binding with $\mathrm{Bcl}-2$ and/or Bcl-xL located in the mitochondrial membrane (Yang et al. 1995; Zha et al., 1996). In recent years, reversible phosphorylation of Bad has been clearly demonstrated and shown to regulate apoptosis (Figure 2.2) (Bae et al., 2001, Yan et al., 2003, Chiang et al., 2003, Chen et al., 2005).

Degradation of chromosomal DNA is a hallmark of apoptosis. Late in the apoptotic process, caspase-activated endogenous endonucleases cleave chromosomal DNA between the nucleosomes, generating a series of DNA fragments with multiples of 180 to 220 bases (Smith et al., 1996; Nagata, 2000). These fragments form a ladder when the extracted DNA is separated by gel electrophoresis and stained by ethidium bromide. DNA laddering was used as a test for the degree of apoptosis of cells in the organs of frozen frogs. This laddering correlates with activation of many apoptotic pathways; additional methods of measuring apoptosis were not attempted in this thesis. To complement the analysis of pro- and anti-apoptotic proteins in wood frog organs, liver from control, frozen and thawed frogs was examined for evidence of DNA laddering to determine whether freeze/thaw induces apoptosis. 
Figure 2.1 The JAK-STAT signal transduction pathways

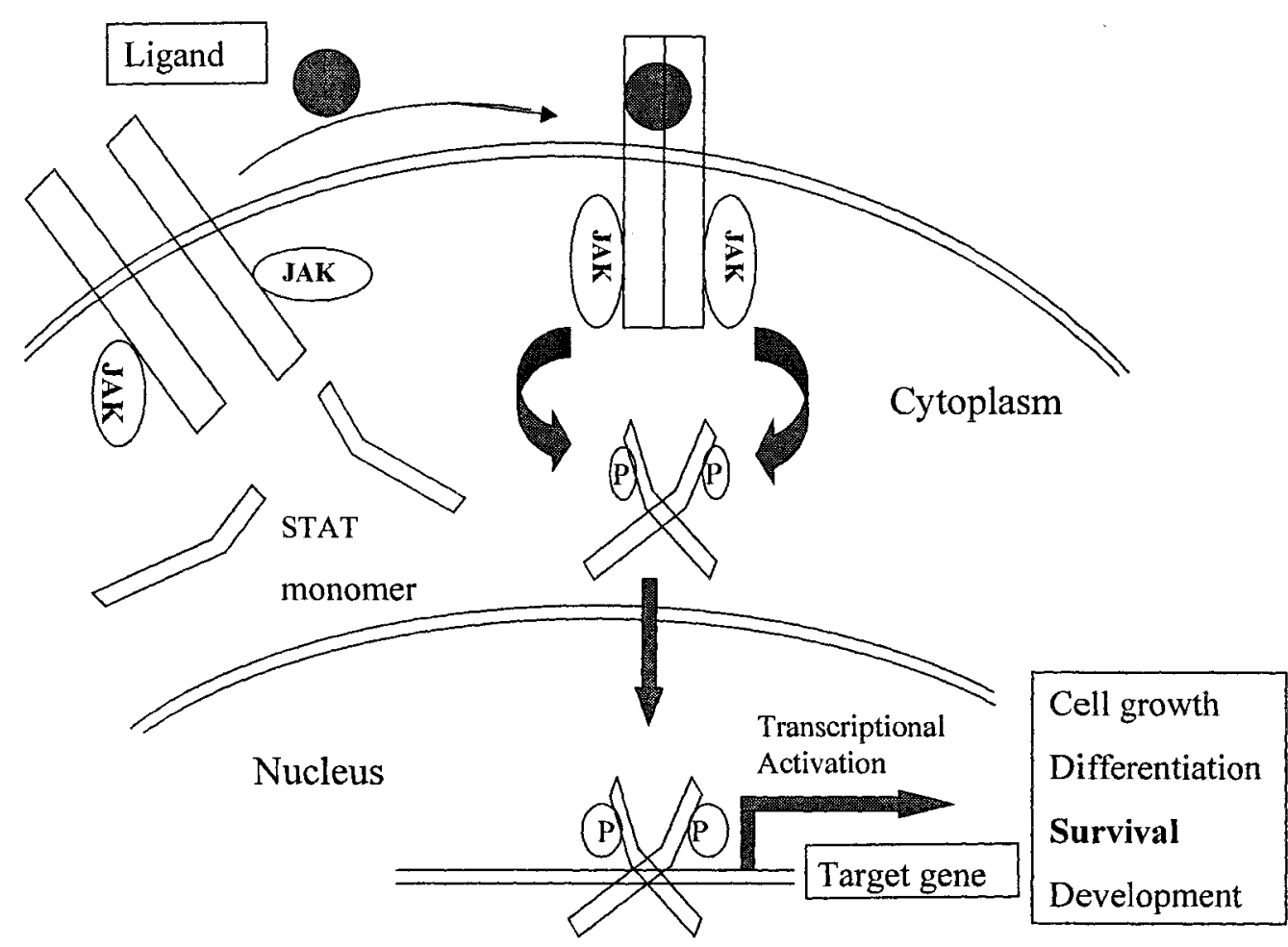


Figure 2.2 Bcl-2 Family Signaling Pathways

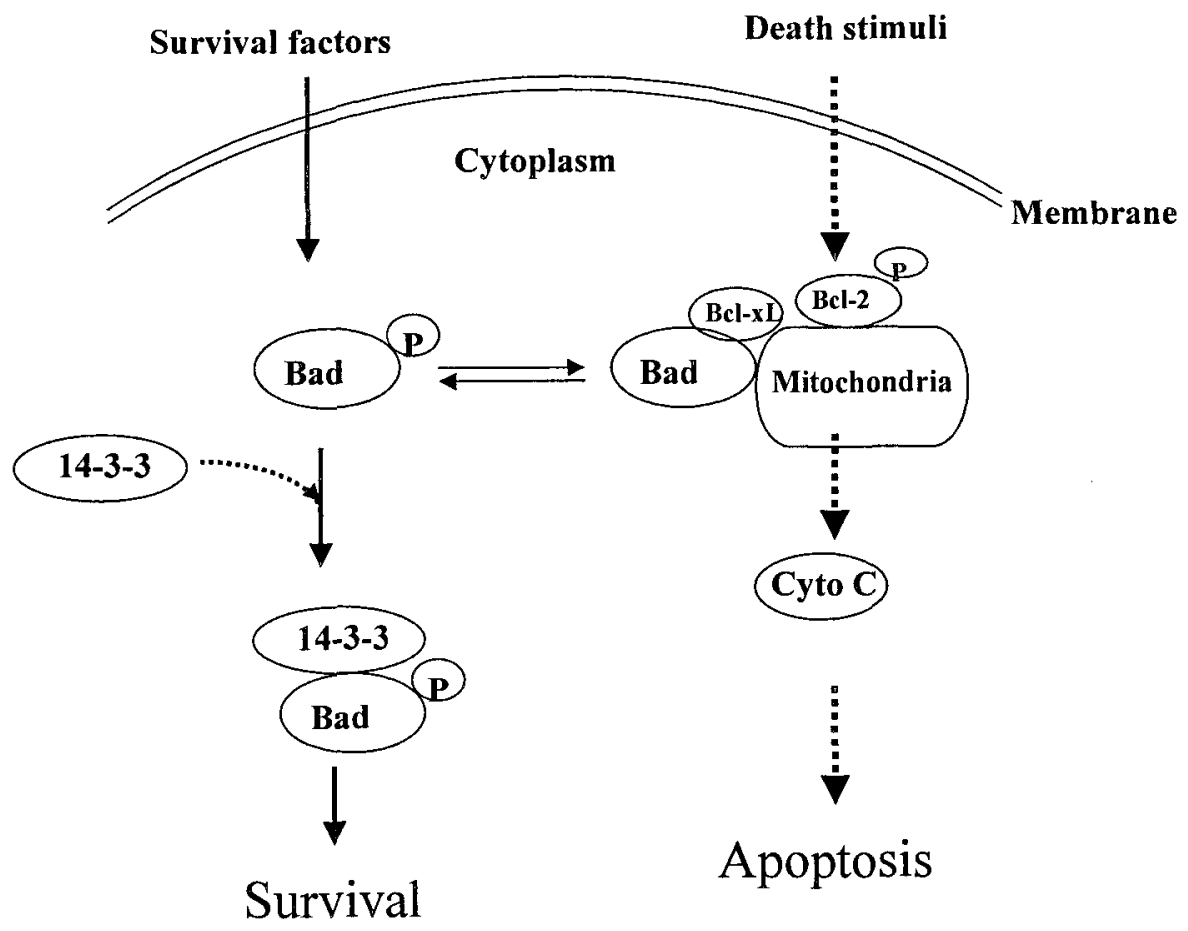




\subsection{Materials and Methods}

\subsubsection{Animal experiments}

Adult male wood frogs, Rana sylvatica, which were 2-3 years old (adult $R$. sylvatica live only about 3 years; they can breed first in the spring of their second year), were collected from breeding ponds in the Ottawa area in the spring of 2003. Tadpoles are not freeze tolerant but all ages of adults are completely freeze tolerant. Isolated tissues from the wood frogs cannot be used for freeze tolerance studies, because without a blood perfusion system containing the natural blood-borne nucleating proteins, isolated organs supercool and do not freeze. There are no cell lines available for any freeze tolerant frog, including $R$. sylvatica. Cell lines are only available from the African clawed frog, Xenopus laevis, and these cells can not survive freezing. So we choose the whole wood frog as the study model. Frogs were washed in a tetracycline bath and held at $5^{\circ} \mathrm{C}$ in a container with sphagnum moss for 1-2 weeks before experimentation. Control frogs were sampled directly from this condition. For freezing exposure, wood frogs were placed in closed plastic containers lined with damp paper towels and transferred to another incubator at $-2.5^{\circ} \mathrm{C}$. The damp toweling ensures that all animals are rapidly seeded when ice begins to form on the substrate. Under this condition, frogs cooled below $0^{\circ} \mathrm{C}$ and started to freeze within $\sim 45 \mathrm{~min}$, as determined from initial trials with frogs that had thermistors taped to their abdomens (Storey and Storey, 1985a). After this period of chilling, the length of freezing exposure was timed and some frogs were sampled after $24 \mathrm{~h}$ of freezing at $-2.5^{\circ} \mathrm{C}$. Other frogs were frozen for $24 \mathrm{~h}$ at $-2.5^{\circ} \mathrm{C}$ and then returned to $5^{\circ} \mathrm{C}$; they were allowed to thaw and were sampled after $8 \mathrm{~h}$. All frogs were killed by pithing and each was dissected within $30-90 \mathrm{sec}$ with the group co- 
operation of 3-5 persons. Tissues were flash frozen in liquid nitrogen and transferred for storage to a $-80^{\circ} \mathrm{C}$ freezer. Tissues sampled included brain, heart, liver, kidney, gut (stomach and intestine), hind leg thigh skeletal muscle, and abdominal skin.

For anoxia exposure, frogs were treated essentially as described by Holden and Storey (1997). After 1 week of acclimation at $5^{\circ} \mathrm{C}$, frogs were transferred to $700 \mathrm{ml}$ jars ( 5 frogs per bottle) held in crushed ice and containing $5 \mathrm{ml}$ of distilled water, which had been bubbled with $100 \% \mathrm{~N}_{2}$ for $30 \mathrm{~min}$. Jars were tightly capped and sealed with a covering of parafilm and $\mathrm{N}_{2}$ gassing was continued for another $30 \mathrm{~min}$ through syringe ports in the caps. Gas lines were then removed and bottles were sealed and placed into a $5^{\circ} \mathrm{C}$ incubator for 24 hours. At the end of this time, jars were transferred back to a crushed ice bath, gas lines were quickly reintroduced to maintain the anoxic atmosphere and then animals were quickly sampled. Some frogs were made anoxic for 24 hours and then transferred to a new jar and allowed to recover from anoxia for 4 hours in a $5^{\circ} \mathrm{C}$ incubator.

Dehydration experiments were conducted as described by Churchill and Storey (1993). Frogs were individually tagged for identification and weighed. They were then placed in closed jars (5-6 frogs per jar) with a layer of silica gel desiccant on the bottom separated from the frogs by a $1 \mathrm{~cm}$ thickness of sponge. Jars were held at $5^{\circ} \mathrm{C}$. At intervals, animals were removed and quickly weighed. The change in mass was used to calculate the percentage of body water lost via the following equation: $(\mathrm{Mi}-\mathrm{Md}) /(\mathrm{Mi} \mathrm{x}$ $\% \mathrm{H}_{2} \mathrm{O}$ ), where $\mathrm{Mi}$ is the initial mass of an individual, $\mathrm{Md}$ is the mass at each weighing, and $\% \mathrm{H}_{2} \mathrm{O}$ is the percentage of total body mass that is in water in control frogs This value is $80.8 \pm 1.2 \%$ for $R$. sylvatica (Churchill and Storey, 1993). The mean rate of 
body water loss under these conditions was $0.5 \%$ of total body water lost per hour. Frogs were sampled after they reached $40 \%$ of total body water lost. Other frogs were first dehydrated to $40 \%$ of water lost and then transferred into jars containing $1 \mathrm{~cm}$ distilled water. They were allowed to fully rehydrate at $5^{\circ} \mathrm{C}$ and sampled after $24 \mathrm{~h}$.

\subsubsection{Western blotting}

Western blots are presented as changes in the relative amounts of protein in each tissue. Each individual tissue has a different amount of soluble protein.

\subsubsection{Isolation of total protein from frog tissues}

Total soluble protein (proteins remaining in the supernatant after centrifugation; integral membrane proteins are not present in our preparations and can only be obtained by the further extraction of pellets with SDS.) was extracted from tissues of control, $24 \mathrm{~h}$ frozen and $8 \mathrm{~h}$ thawed groups of frogs. Samples of frozen tissues were weighed and then quickly homogenized in buffer $(1: 10 \mathrm{w} / \mathrm{v})$ containing $20 \mathrm{mM}$ HEPES pH 7.8, $200 \mathrm{mM}$ $\mathrm{NaCl}, 0.1 \mathrm{mM}$ EDTA, $10 \mathrm{mM} \mathrm{NaF}, 1 \mathrm{mM} \mathrm{NaVO}_{3}$, and $10 \mathrm{mM} \beta$-glycerophosphate with $0.1 \mathrm{mM}$ phenylmethylsulfonyl fluoride (PMSF) added prior to homogenization and using a Polytron PT 1000. Samples were centrifuged for $15 \mathrm{~min}$ at $15,000 \times \mathrm{g}$ at $4^{\circ} \mathrm{C}$ and supernatant was stored in a freezer at $-80^{\circ} \mathrm{C}$.

\subsubsection{Measurement of protein concentration}

Protein concentrations were determined by the Coomassie blue dye-binding method (Bradford, 1976) with the Bio-Rad prepared reagent and bovine serum albumin as the standard. The reagent was diluted 5-fold with distilled water and protein extracts of 
tissues were diluted 1:20 (v:v). For assay, $10 \mu \mathrm{l}$ protein samples were added to $190 \mu \mathrm{l}$ of dye reagent in microplate wells followed by mixing and $10 \mathrm{~min}$ incubation at room temperature (RT). Absorbance at $595 \mathrm{~nm}$ was read and protein concentration was determined from a pre-programmed standard curve using BioLinx 2.0 software.

\subsubsection{SDS polyacrylamide gel electrophoresis}

Protein samples were mixed 1:1 (v:v) with 2x SDS-PAGE sample buffer containing $100 \mathrm{mM}$ Tris- $\mathrm{HCl}(\mathrm{pH} 6.8), 4 \%$ SDS (w/v), 20\% glycerol (v/v), 5\% $\beta$ mercaptoethanol (v/v) and $0.2 \%$ bromophenol blue (w/v) and boiled for $5 \mathrm{~min}$. On any given gel, the same amount of protein was loaded into each well. Generally, aliquots containing 10-15 $\mu \mathrm{g}$ protein (See Table 2.1) were loaded into each well of $10 \%$ or $15 \%$ acrylamide gels (acrylamide:bis-acrylamide 29.2:0.8; w/w) using the discontinuous buffer system of Laemmli (1970). The acrylamide percentage varied depending on the estimated subunit molecular weight of the target protein to be analyzed (See Table 2.1). Electrophoresis was carried out on a Bio-Rad mini-gel apparatus at $180 \mathrm{~V}$ for $40-50 \mathrm{~min}$ at RT with $1 \mathrm{x}$ running buffer containing $3.03 \mathrm{~g}$ Tris base, $14.4 \mathrm{~g}$ glycine and $1 \mathrm{~g}$ SDS per liter, $\mathrm{pH} \sim 8.3$. Proteins were then transferred to polyvinylidene difluoride (PVDF) membranes (Immobilon-P Transfer Membrane, Millipore Corp. Bedford, MA) at $180 \mathrm{~mA}$ for $1.5 \mathrm{~h}$ at $4^{\circ} \mathrm{C}$ with transfer buffer containing $25 \mathrm{mM}$ Tris $\mathrm{pH} 8.5,192 \mathrm{mM}$ glycine and $20 \% \mathrm{v} / \mathrm{v}$ methanol. PVDF membranes were then blocked with $2.5 \%$ non-fat milk in TBST (20 mM Tris, pH 7.5, $150 \mathrm{mM} \mathrm{NaCl,} \mathrm{0.05 \%} \mathrm{Tween-20)} \mathrm{for} 25 \mathrm{~min}$ at RT (See Table 2.1). The blot was rinsed with TBST and incubated with primary antibody on a shaking platform, either for $2 \mathrm{~h}$ at $\mathrm{RT}$ or overnight at $4{ }^{\circ} \mathrm{C}$ (See Table 2.1). The primary 
antibodies that were used and their dilutions are given in Table 2.2. Blots were then washed twice with TBST for $10 \mathrm{~min}$ and incubated with secondary antibody at the appropriate dilution (Table 2.1) in TBST according to manufacturer's instructions for 1 2 $\mathrm{h}$ at RT. Blots were then washed 2 times for $20 \mathrm{~min}$ with TBST and bands were visualized by adding $2 \mathrm{ml}$ of enhanced chemiluminescence (ECL) reagent (NEN Life Science Products, Boston, MA) with detection and quantification via a Bio-Rad SynGene using Gene Tools software.

Total protein was then visualized on the PVDF membranes by staining for $30 \mathrm{~min}$ with Coomassie blue $[0.25 \%$ Coomassie Brilliant Blue R (w:v), $50 \%$ methanol (v:v) and $7.5 \%$ acetic acid (v:v)] followed by destaining for 10 min with destain solution $(50 \mathrm{ml}$ distilled water, $50 \mathrm{ml}$ acetic acid and $150 \mathrm{ml}$ methanol). An appropriate band (or bands) that did not change in intensity between experimental conditions was chosen on each blot and quantification of these Coomassie-stained band intensities confirmed equal loading of protein into each lane. Immunoblot band intensities in each lane were then normalized against the corresponding Coomassie blue "standard" band in that lane. Statistical analysis used the Student's t-test to compare normalized experimental band intensities $(\mathrm{n}=4)$ to normalized control values $(\mathrm{n}=4)$ with $\mathrm{P}<0.05$ accepted as significantly different.

\subsubsection{Assessment of DNA laddering}

Samples $(\sim 0.1 \mathrm{~g})$ of frozen tissue were ground into powder under liquid nitrogen using a mortar and pestle and then lysed by suspending samples in $600 \mu \mathrm{l}$ of TE buffer (10 mM Tris, pH 8.0, 1mM EDTA) containing $0.2 \%(\mathrm{v} / \mathrm{v})$ Triton X-100. Following incubation on ice for $10 \mathrm{~min}$, the tubes were gently swirled to resuspend the samples 
followed by centrifugation at $13,000 \times \mathrm{g}$ for $15 \mathrm{~min}$ at $4^{\circ} \mathrm{C}$. Supernatants that contained the low molecular weight DNA were transferred to fresh microcentrifuge tubes, $1.2 \mu 1$ of $10 \mathrm{mg} / \mathrm{ml}$ Rnase A was added to each tube, and the samples were incubated for $1 \mathrm{~h}$ at $37^{\circ} \mathrm{C}$. Subsequently, $25 \mu \mathrm{l}$ of $10 \%$ SDS and $3.4 \mu \mathrm{l}$ of $20 \mu \mathrm{g} / \mathrm{ml}$ Proteinase $\mathrm{K}$ was added and then samples were incubated for $1 \mathrm{~h}$ at $50^{\circ} \mathrm{C}$. Following addition of $53 \mu \mathrm{l}$ of $5 \mathrm{M}$ $\mathrm{NaCl}$ and $512 \mu \mathrm{l}$ of $-20^{\circ} \mathrm{C}$ isopropanol, tubes were incubated on ice for $10 \mathrm{~min}$, and then centrifuged at $13,000 \mathrm{x}$ g for $15 \mathrm{~min}$ at $4^{\circ} \mathrm{C}$. The supernatants were decanted by inverting the tubes on a Kimwipe followed by dissolving the DNA pellets in $50 \mu \mathrm{l}$ of TE buffer.

DNA concentrations in samples were quantified spectrophotometrically at $260 \mathrm{~nm}$ and $280 \mathrm{~nm}$, an optical density of 1.0 is equivalent to a DNA concentration of $50 \mu \mathrm{g} / \mathrm{ml}$. Depending on the DNA concentration in the samples, sufficient Gel Loading Buffer (0.005\% w/v Bromophenol Blue, 0.005\% w/v Xylene Cyanol, $0.2 \mathrm{mM}$ EDTA, $8.9 \mathrm{mM}$ Tris $\mathrm{pH} 8.0,8.9 \mathrm{mM}$ boric acid, $6 \% \mathrm{w} / \mathrm{v}$ sucrose) was added into samples. Following the same amounts of microgram of DNA for each sample loading into the wells, the samples were run in a $1.2 \%$ agarose gel with a $1 \mathrm{~kb}$ DNA ladder for $1.5 \mathrm{~h}$. Bands on the gel were visualized under UV light using the SynGene. 
Table 2.1 Experimental Conditions of western blotting

\begin{tabular}{|c|c|c|c|c|}
\hline Proteins & $\begin{array}{l}\text { Percent } \\
\text { Acrylamide } \\
\text { in Gel }\end{array}$ & $\begin{array}{c}\text { Protein } \\
\text { amount } \\
\text { loaded into } \\
\text { wells }(\boldsymbol{\mu} \text { g) }\end{array}$ & $\begin{array}{c}\text { Time of blocking } \\
\text { the membranes } \\
\text { with 2.5\% milk } \\
\text { (min) }\end{array}$ & $\begin{array}{c}\text { Time of incubation } \\
\text { with primary } \\
\left.\text { antibodies (at } \mathbf{4}^{\circ} \mathbf{C}\right)\end{array}$ \\
\hline $\begin{array}{c}\text { phospho- } \\
\text { Stat5(Tyr694) }\end{array}$ & $10 \%$ & 10 & $\sim 5$ & Overnight \\
\hline $\begin{array}{c}\text { phospho- } \\
\text { Stat1(Tyr701) }\end{array}$ & $10 \%$ & 10 & $\sim 5$ & Overnight \\
\hline $\begin{array}{c}\text { phospho- } \\
\text { Stat3(Ser727) }\end{array}$ & $10 \%$ & 10 & $\sim 5$ & Overnight \\
\hline $\begin{array}{c}\text { Bcl-2 (N-19) } \\
\text { phospho- } \\
\text { Bcl-2 (Ser70) }\end{array}$ & $15 \%$ & 75 & $\sim 15$ & 3 days \\
\hline $\begin{array}{c}\text { Bcl-xL } \\
\text { (H-62) }\end{array}$ & $15 \%$ & 75 & $\sim 15$ & 2 days \\
\hline $\begin{array}{c}\text { Bad } \\
\text { (Ser112) }\end{array}$ & $15 \%$ & 75 & $\sim 10$ & Overnight \\
\hline $\begin{array}{c}\text { phospho-Bad } \\
\text { (S) }\end{array}$ & $15 \%$ & 75 & $\sim 10$ & \\
\hline
\end{tabular}


Table 2.2 Antibodies used in western blotting

\begin{tabular}{|c|c|c|c|}
\hline Proteins & $\begin{array}{l}\text { Primary antibodies } \\
\text { and dilutions }(V: V)\end{array}$ & $\begin{array}{l}\text { Secondary antibodies } \\
\text { and dilutions }(V: V)\end{array}$ & Sources \\
\hline $\begin{array}{l}\text { phospho-Stat5 } \\
\text { (Tyr694) }\end{array}$ & $\begin{array}{l}\text { Rabbit Anti-phospho- } \\
\text { Stat5 (Tyr694) } \\
\text { Polyclonal Antibody } \\
(1: 1000)\end{array}$ & $\begin{array}{l}\text { Anti-rabbit IgG HRP- } \\
\text { linked antibody } \\
(1: 2000)\end{array}$ & $\begin{array}{c}\text { Cell Signaling } \\
\text { Technology, } \\
\text { Beverly, MA }\end{array}$ \\
\hline $\begin{array}{l}\text { phospho-Stat } 1 \\
\text { (Tyr701) }\end{array}$ & $\begin{array}{c}\text { Rabbit Anti-phospho- } \\
\text { Stat1 (Tyr701) } \\
\text { Polyclonal Antibody } \\
(1: 1000)\end{array}$ & $\begin{array}{l}\text { Anti-rabbit IgG HRP- } \\
\text { linked antibody } \\
(1: 2000)\end{array}$ & $\begin{array}{c}\text { Cell Signaling } \\
\text { Technology, } \\
\text { Beverly, MA }\end{array}$ \\
\hline $\begin{array}{l}\text { phospho-Stat3 } \\
\text { (Ser727) }\end{array}$ & $\begin{array}{c}\text { Rabbit Anti-phospho- } \\
\text { Stat3 (Ser727) } \\
\text { Polyclonal Antibody } \\
(1: 1000)\end{array}$ & $\begin{array}{c}\text { Anti-rabbit IgG HRP- } \\
\text { linked antibody } \\
(1: 2000)\end{array}$ & $\begin{array}{c}\text { Cell Signaling } \\
\text { Technology, } \\
\text { Beverly, MA }\end{array}$ \\
\hline $\mathrm{Bcl}-2$ (N-19) & $\begin{array}{l}\text { Rabbit Anti-Bcl-2 (N- } \\
\text { 19) Polyclonal Antibody } \\
(1: 250)\end{array}$ & $\begin{array}{l}\text { Anti-rabbit IgG HRP- } \\
\text { linked antibody } \\
(1: 2000)\end{array}$ & $\begin{array}{c}\text { Santa Cruz } \\
\text { Biotechnology, } \\
\text { Santa Cruz, CA }\end{array}$ \\
\hline $\begin{array}{l}\text { phospho- } \\
\text { Bcl-2 } \\
\text { (Ser 70) }\end{array}$ & $\begin{array}{l}\text { Rabbit Anti-phospho- } \\
\text { Bcl-2 (Ser70) polyclonal } \\
\text { antibody (1:1000) }\end{array}$ & $\begin{array}{l}\text { Anti-rabbit IgG HRP- } \\
\text { linked antibody } \\
(1: 2000)\end{array}$ & $\begin{array}{l}\text { Cell Signaling } \\
\text { Technology, } \\
\text { Beverly, MA }\end{array}$ \\
\hline Bcl-xL (H-62) & $\begin{array}{l}\text { Rabbit Polyconal } \\
\text { Antibody }(1: 200)\end{array}$ & $\begin{array}{l}\text { Anti-rabbit IgG HRP- } \\
\text { linked antibody } \\
(1: 2000)\end{array}$ & $\begin{array}{c}\text { Santa Cruz } \\
\text { Biotechnology, } \\
\text { Santa Cruz, CA }\end{array}$ \\
\hline $\mathrm{Bad}$ & $\begin{array}{c}\text { Rabbit Polycolonal } \\
\text { Antibody } \\
(1: 1000)\end{array}$ & $\begin{array}{l}\text { Anti-rabbit IgG HRP- } \\
\text { linked antibody } \\
(1: 2000)\end{array}$ & $\begin{array}{c}\text { Cell Signaling, } \\
\text { Technology,Inc } \\
\text { Beverly, MA }\end{array}$ \\
\hline $\begin{array}{c}\text { phospho- } \\
\text { Bad (Ser112) }\end{array}$ & $\begin{array}{c}\text { Rabbit Anti- } \\
\text { phospho-Bad (Ser112) } \\
\text { Polyclonal Antibody } \\
(1: 1000)\end{array}$ & $\begin{array}{l}\text { Anti-rabbit IgG HRP- } \\
\text { linked antibody } \\
(1: 2000)\end{array}$ & $\begin{array}{c}\text { Cell Signaling } \\
\text { Technology, } \\
\text { Inc. } \\
\text { Beverly, MA }\end{array}$ \\
\hline
\end{tabular}




\subsection{Results}

From STATs family members, phospho-Stat1 (Tyr701), phospho-Stat2 (Tyr690), phospho-Stat3 (Tyr705), phospho-Stat3 (Ser727), phospho-Stat5 (Tyr694) and phosphostat6 (Tyr641) were detected in frog tissues. Only three antibodies worked, including rabbit anti-phospho-Stat1 (Tyr701), rabbit anti-phospho-Stat3 (Ser727) and rabbit antiphospho-Stat5 (Tyr694).

\subsubsection{Phospho-Stat5 (Tyr694) protein expression}

Western blotting was used to assess the content of phosphorylated Stat5 (Tyr694) protein in four tissues from wood frogs comparing $15^{\circ} \mathrm{C}$ acclimated controls with frogs frozen for $24 \mathrm{~h}$ at $-2.5^{\circ} \mathrm{C}$ and frogs thawed at $5^{\circ} \mathrm{C}$ for $8 \mathrm{~h}$ after $24 \mathrm{~h}$ frozen. Figure 2.3 shows that the levels of phospho-Stat5 (Tyr694) decreased significantly $(\mathrm{P}<0.05)$ by $67 \%$ during freezing in liver and remained low at $59 \%$ below control values after thawing. By contrast, the opposite response was seen in other tissues. In skeletal muscle, phosphoStat5 (Tyr694) levels increased by 1.4-fold during freezing and continued to rise to 1.7fold above control levels $(\mathrm{P}<0.05)$ after thawing. The same trend was seen in skin; phospho-Stat5 (Tyr694) protein content increased significantly $(\mathrm{P}<0.05)$ by 1.6 -fold and 2.3-fold, respectively, during freezing and thawing. In kidney, the level of this protein did not change during freezing, but it increased significantly $(\mathrm{P}<0.05)$ by 2.5 -fold during thawing.

Anoxia exposure and dehydration mimic two of the components of freezing stress; ischemia/anoxia develops in all tissues due to plasma freezing and cellular dehydration results due to cell water loss into extracellular ice masses. Previous studies have shown 
that many of the freeze-induced responses seen in wood frogs are also triggered as responses to either anoxia or freezing (Storey and Storey, 2004). The responses of phospho-Stat5 (Tyr694) in wood frog organs to anoxia or dehydration exposures are shown in Figure 2.2. Anoxia exposure $\left(24 \mathrm{~h}\right.$ under nitrogen gas at $\left.5^{\circ} \mathrm{C}\right)$ had no effect on phospho-Stat5 (Tyr694) levels in liver or kidney but the amount of phosphorylated transcription factor had increased significantly $(\mathrm{P}<0.05)$ by 1.5 -fold and 1.4 -fold, respectively, after $4 \mathrm{~h}$ aerobic recovery after $24 \mathrm{~h}$ anoxia exposure (Figure 2.4B). On the other hand, the amount of phospho-protein decreased significantly $(\mathrm{P}<0.05)$ by $38 \%$ and $40 \%$, respectively, in skeletal muscle and skin during anoxia exposure but had partially recovered after $4 \mathrm{~h}$ of aerobic recovery.

As Figure 2.4 (C) shows, dehydration had no significant effect on the content of phospho-Stat5 (Tyr694) in muscle and kidney tissues. However, the level of the phosphoprotein in skin increased $(\mathrm{P}<0.05)$ significantly by 1.4 -fold during dehydration and then fell to $80 \%$ of the control value after $8 \mathrm{~h}$ recovery. Phospho-Stat5 (Tyr694) content was stable during dehydration in liver but it increased $(\mathrm{P}<0.05)$ by 1.3 -fold after recovery.

\subsubsection{Phospho-Stat1 (Tyr701) and Phospho-Stat3 (Ser727) expression}

Western blotting was also used to assess the levels of phospho-Stat1 (Tyr701) and phospho-Stat3 (Ser727) in tissues of wood frogs. Figure 2.5 (B) shows that phosphoStat1 (Tyr701) content decreased significantly $(\mathrm{P}<0.05)$ by $47 \%$ during freezing in liver and fell even lower during thawing (by $62 \%$ as compared with control). Unlike the situation in liver, however, the amount of phosphorylated protein increased $(\mathrm{P}<0.05)$ in skeletal muscle and kidney during freezing; levels rose by 1.8 -fold in skeletal muscle and 
2.0-fold in kidney. During thawing, levels rose even more in both tissues, increasing by 3.8-fold and 9.9-fold $(\mathrm{P}<0.05)$, respectively. Freeze/thaw had no effect on phospho-Stat1 (Tyr701) content in skin.

Figure 2.5 (C) demonstrates that phospho-Stat3 (Ser727) protein content increased significantly $(\mathrm{P}<0.05)$ during freezing by 2.6 -fold in liver and by 2.2 -fold in skin. After thawing this effect was reversed; phospho-Stat3 (Ser727) content was 38\% lower than the control value in liver, and 1.2-fold higher than control in skin after $8 \mathrm{~h}$ of thawing.

\subsubsection{Bcl-2 and phospho-Bcl-2 (ser70) protein expression}

The effects of freeze and thaw on the total protein content of $\mathrm{Bcl}-2$ and the relative amount of phosphorylated Bcl-2 (Ser70) in liver, skeletal muscle and kidney of wood frogs were also examined via western blotting. The anti-Bcl-2 and anti-phosphoBcl-2 (Ser70) polyclonal antibodies cross-reacted with a single band at the expected molecular weight of the protein $(\sim 28 \mathrm{kDa})$. Figure $2.6(\mathrm{C})$ shows that the total amount of Bcl-2 protein did not change during freezing in liver but it increased significantly $(\mathrm{P}<0.05)$ during thawing by 1.6 -fold. However, the content of phosphorylated Bcl-2 (Ser 70) rose significantly $(\mathrm{P}<0.05)$ during both freezing and thawing by 1.6 -fold and 2.4 -fold, respectively. In skeletal muscle, the amount of $\mathrm{Bcl}-2$ protein rose significantly $(\mathrm{P}<0.05)$ during freezing by 1.5 -fold, but then returned the control level after thawing. PhosphoBcl-2 content in muscle was stable during freezing and increased significantly $(\mathrm{P}<0.05)$ during thawing by 1.7 -fold as compared with the control. Bcl-2 content in kidney decreased during freezing by $44 \%$ and continued to fall during thawing, decreasing significantly by $71 \%(\mathrm{P}<0.05)$ as compared with the control value. By contrast, the 
content of phospho-Bcl-2 (Ser70) in kidney increased significantly $(\mathrm{P}<0.05)$ by 5.3 -fold and 11.5-fold, respectively, during freezing and thawing.

\subsubsection{Western blotting analysis of Bcl-xL protein expression}

Immunoblotting was also used to determine the contents of $\mathrm{Bcl}-\mathrm{xL}$ protein in some organs of wood frogs. The Bcl-xL antibody cross-reacted with a single band at the expected molecular weight of $\sim 32 \mathrm{kDa}$. Figure 2.7 shows that levels of the protein were stable during freezing and thawing in liver and skeletal muscle. The content of Bcl-xL protein also did not change during freezing in kidney, but increased significantly $(\mathrm{P}<0.05)$ by 2.3 -fold during thawing.

\subsubsection{Bad and phospho-Bad (Ser112) protein expression}

Western blotting was also performed to assess Bad, phospho-Bad (Ser112), phospho-Bad (Ser136) and phospho-Bad (Ser155) contents in some tissues of wood frogs. For phospho-Bad, only phospho-Bad (Ser112) worked in frog tissues. Initial studies showed that the antibodies crossreacted with only a single band at the expected molecular weight of $\sim 23 \mathrm{kDa}$ for the protein. Figure 2.8(C) shows that Bad content in liver was strongly and significantly increased $(\mathrm{P}<0.05)$ by 10 -fold after $24 \mathrm{~h}$ freezing and remained 4.9-fold higher than control values after $8 \mathrm{~h}$ of thawing. However, despite the strong increase in total Bad protein levels, the content of phosphorylated Bad (Ser 112) in liver decreased strongly by $95 \%(\mathrm{P}<0.05)$ during freezing but rose again to $65 \%$ of the control after $8 \mathrm{~h}$ thawing. Similar responses were seen in skeletal muscle. Bad content increased significantly $(\mathrm{P}<0.05)$ by 5.6 -fold after $24 \mathrm{~h}$ freezing and remained 2.8 -fold 
higher than the control level in thawed animals. Oppositely, the content of phospho-Bad (Ser112) decreased significantly $(\mathrm{P}<0.05)$ in skeletal muscle by $66 \%$ after $24 \mathrm{~h}$ freezing and returned $(\mathrm{P}<0.05)$ to $66 \%$ of the control level after $8 \mathrm{~h}$ thawing. Different effects of freeze/thaw on the contents of Bad and phospho-Bad (Ser112) were seen in wood frog kidney. Bad protein content was stable during freezing, but it increased significantly $(\mathrm{P}<0.05)$ by 7.3 -fold after thawing. The amount of phosphorylated Bad (Ser112) increased significantly $(\mathrm{P}<0.05)$ during freezing by 4.6-fold and continued to rise to 7.1 fold higher than control values after thawing.

\subsubsection{DNA laddering}

To determine whether nuclear DNA fragmentation occurred during freeze/thaw, DNA was isolated from liver of control, frozen and thawed wood frogs and separated on agarose gels. Figure 2.9 shows no indication of DNA laddering in the control frogs and a small amount of DNA laddering in liver of frozen frogs. Distinctly greater amounts of DNA laddering was found in thawed animals. 


\section{Figure 2.3}

Western blot analysis of phospho-Stat5 (Tyr694) protein content in liver, muscle, kidney and skin of wood frogs from three conditions: control $\left(5^{\circ} \mathrm{C}\right.$ acclimated), frozen $\left(24 \mathrm{~h}\right.$ at $\left.-2.5^{\circ} \mathrm{C}\right)$ and thawed recovery $\left(8 \mathrm{~h}\right.$ at $5^{\circ} \mathrm{C}$ after $24 \mathrm{~h}$ frozen).

(A) Representative Western blots showing phospho-Stat5 (Tyr694) protein levels in tissues from control (C), frozen (F) and recovered (R) frogs.

(B) Relative levels of phospho-Stat5 (Tyr694) protein in frozen and thawed frogs as compared with controls. Histogram shows mean $\pm S E M, n=4$ independent determinations. * - Significantly different from the corresponding control value for the same tissue using the Student's t-test, $\mathrm{P}<0.05$. 
(A)

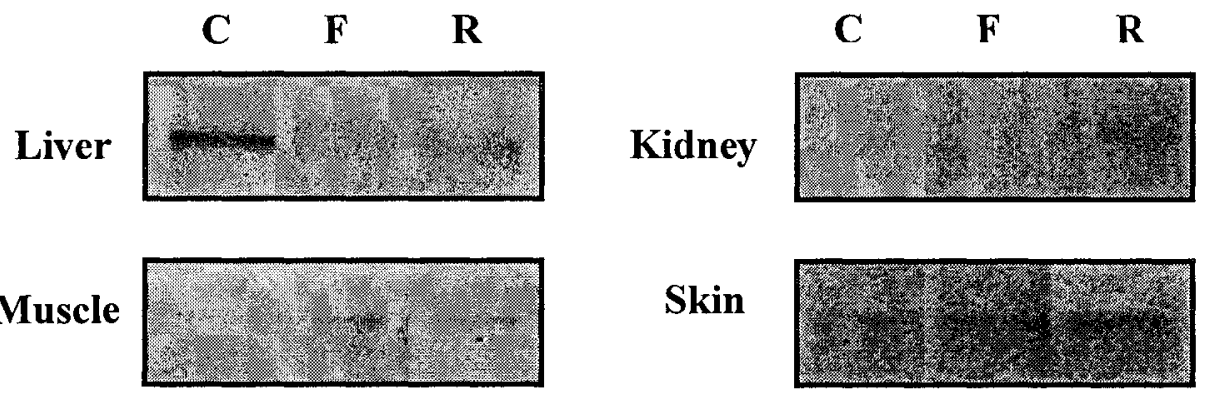

(B)

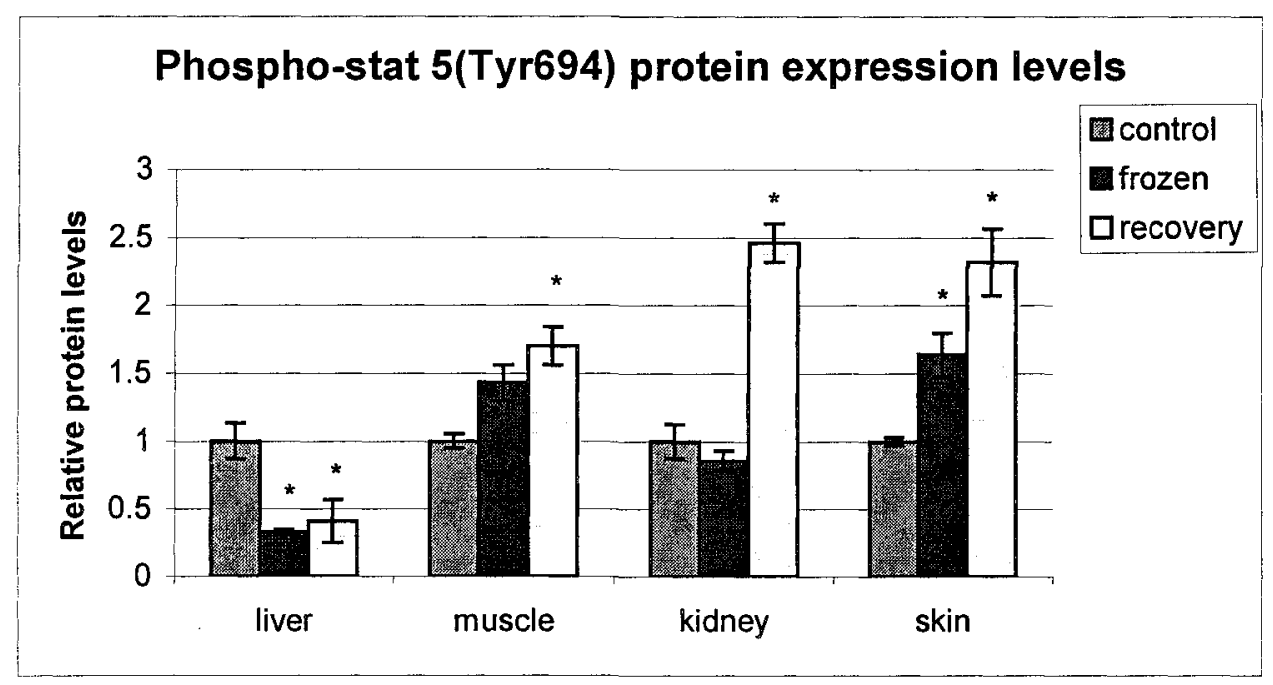




\section{Figure 2.4}

Western blots showing the effects of anoxia and dehydration stresses on phospho-Stat5 (Tyr694) content in wood frog tissues. Anoxia exposure was 24 $\mathrm{h}$ under a nitrogen gas atmosphere at $5^{\circ} \mathrm{C}$ followed by $4 \mathrm{~h}$ aerobic recovery. Dehydration was to $40 \%$ of total body water lost (at $5^{\circ} \mathrm{C}$ ) followed by full rehydration and sampling after $24 \mathrm{~h}$.

(A) Representative Western blots showing phospho-Stat5 (Tyr694) protein levels in tissues from control (C), $24 \mathrm{~h}$ anoxic (A) and aerobic recovery (R) frogs.

(B) Relative levels of phospho-Stat5 (Tyr694) in tissues from anoxic and recovered frogs versus controls. Histogram shows mean \pm SEM, $n=4$ independent determinations. * - Significantly different from the corresponding control values, $\mathrm{P}<0.05$.

(C) Relative levels of phospho-Stat5 (Tyr694) in tissues from dehydrated and rehydrated frogs versus controls. Histogram shows mean $\pm \mathrm{SEM}$, $\mathrm{n}=4$ independent determinations. ${ }^{*}$ - Significantly different from the corresponding control values, $\mathrm{P}<0.05$. 
(A)

C $\quad \mathbf{A} \quad \mathbf{R}$

Liver

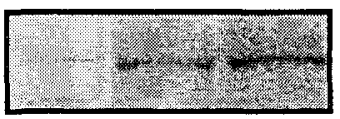

Kidney

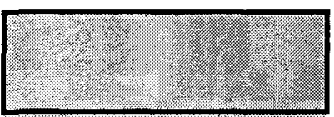

$\mathbf{C} \quad \mathbf{A} \quad \mathbf{R}$

Muscle

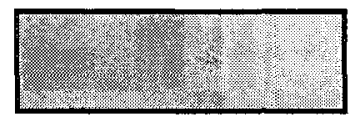

Skin

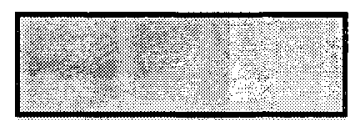

(B)

Phospho-stat 5(Tyr694) protein expression levels

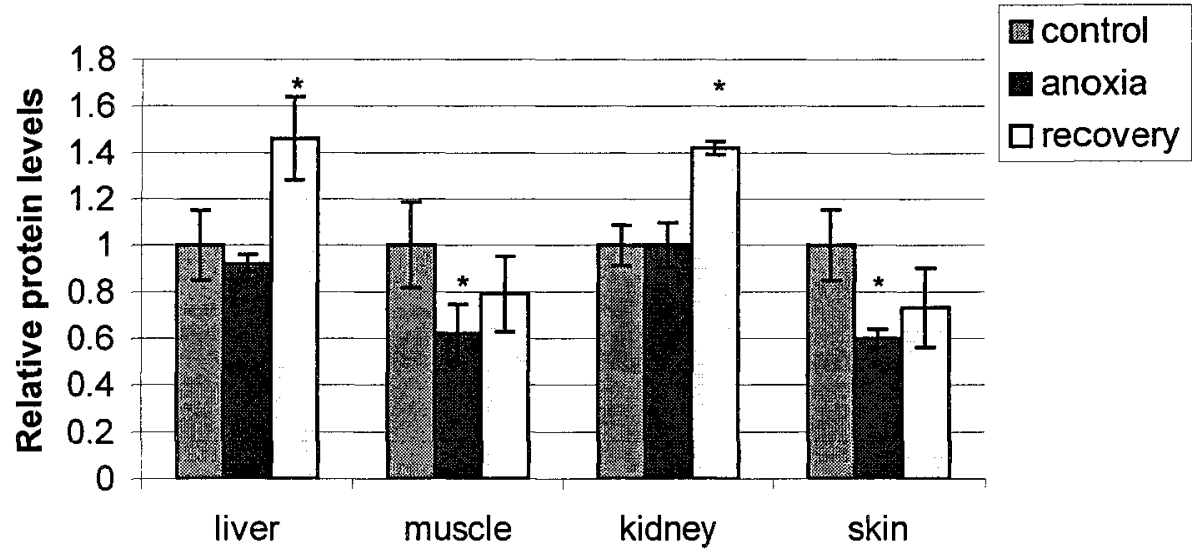

(C)

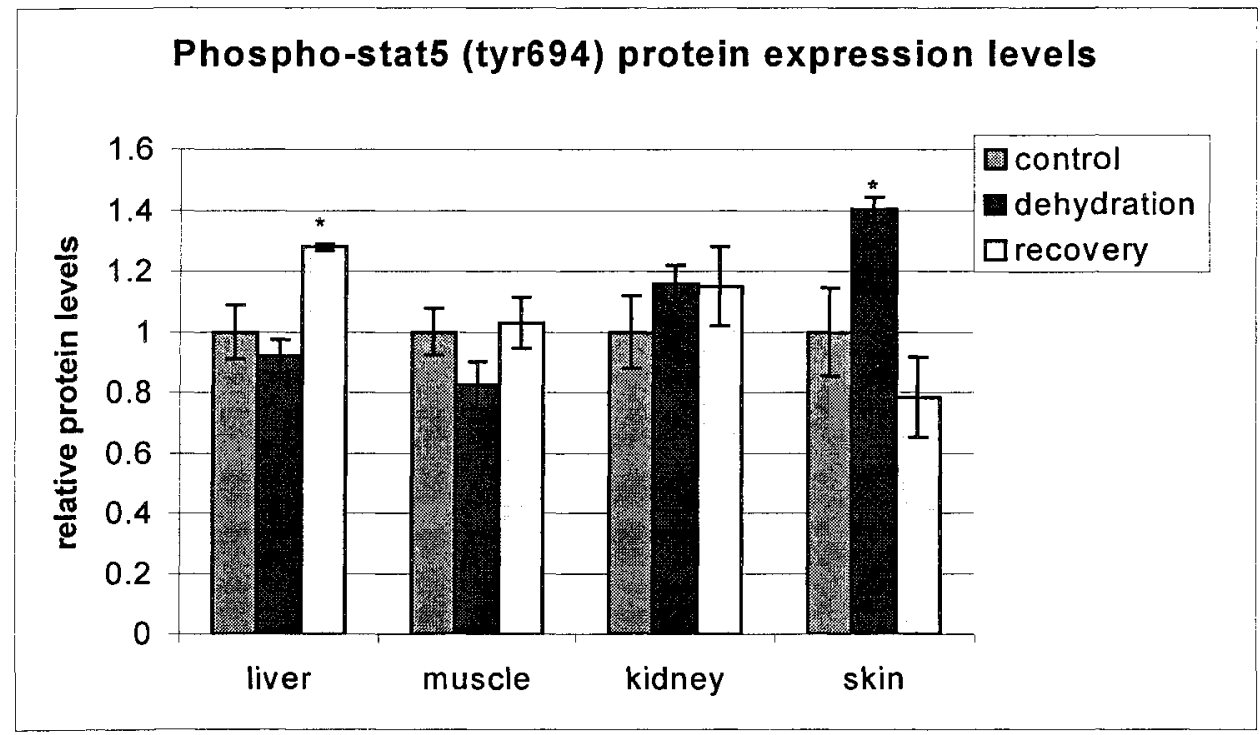




\section{Figure 2.5}

Western blots showing phospho-Stat1 (Tyr701) and phospho-Stat3 (Ser727) protein contents in tissues of control, frozen and thawed wood frogs.

(A) Representative Western blots showing phospho-Stat1 (Tyr701) protein levels in liver, muscle, kidney and skin from control, frozen and thawed recovery frogs.

(B) Relative levels of phospho-Stat1 (Tyr701) protein in wood frog tissues. Histogram shows mean \pm SEM, $\mathrm{n}=4$ independent determinations. * Significantly different from the corresponding control values, $\mathrm{P}<0.05$.

(C) Relative levels of phospho-Stat3 (Ser727) protein in liver and skin of control, frozen and recovered frogs as determined from western blotting. Histogram shows mean \pm SEM, $\mathrm{n}=4$ independent determinations. * Significantly different from the corresponding control values, $\mathrm{P}<0.05$. 
(A)

\section{$\begin{array}{lll}\mathbf{C} & \mathbf{F} & \mathbf{R}\end{array}$}

Liver

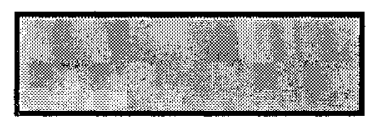

Kidney

(B)

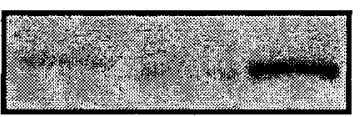

\section{C $\quad$ F $\quad$ R}

Muscle

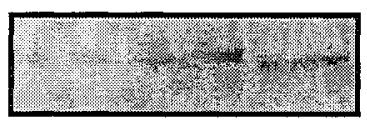

Skin

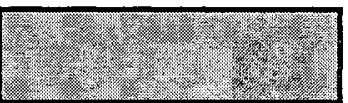

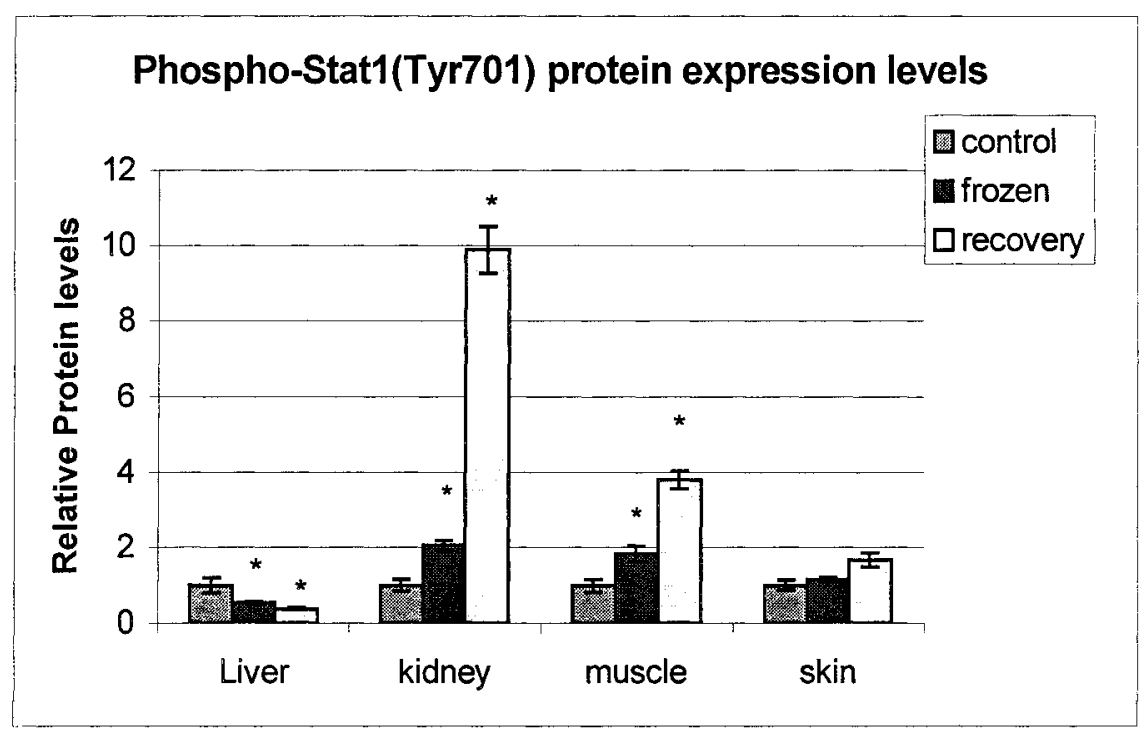

(C)

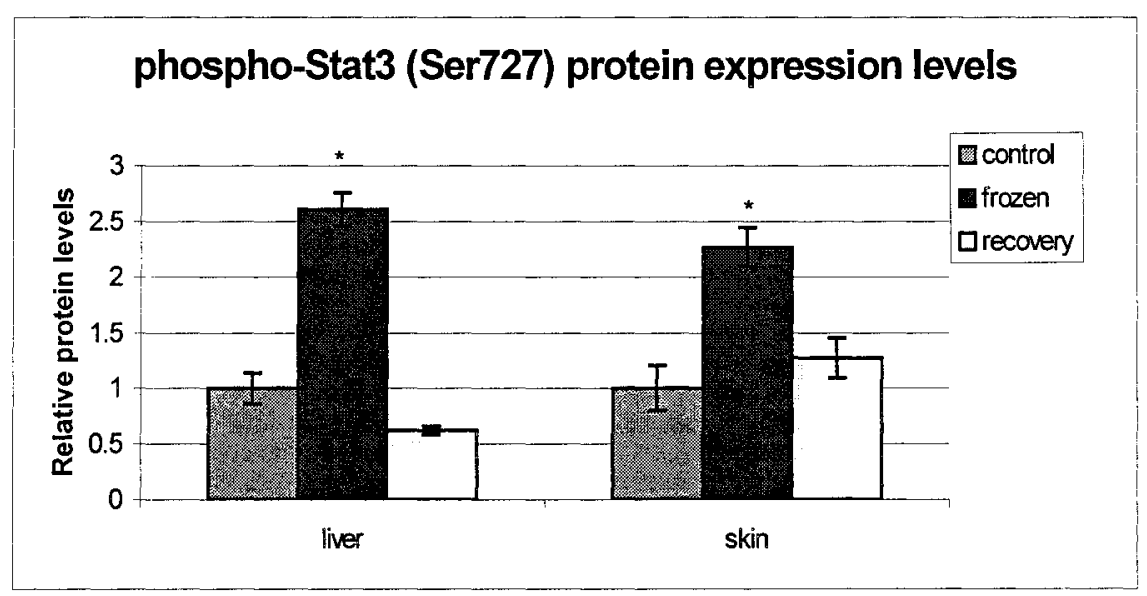




\section{Figure 2.6}

Western blots showing Bcl-2 and phospho-Bcl-2 (Ser70) protein contents in wood frog tissues of control, frozen and recovery samples.

(A) Representative Western blots showing Bcl-2 protein levels in liver, muscle and kidney from control, frozen and recovery samples.

(B) Representative of western blots showing phosphorylated Bcl-2 (Ser70) protein levels in liver, muscle and kidney from control, frozen and recovery samples.

(C) Relative levels of Bcl-2 protein in liver, muscle and kidney of control, frozen and thawed frogs as determined from western blotting. Histogram shows mean \pm SEM, $\mathrm{n}=4$ independent determinations. * Values for frozen or recovery samples were significantly different than the corresponding control values, $\mathrm{P}<0.05$.

(D) Relative levels of phosphorylated Bcl-2 (Ser70) protein in liver, muscle and kidney in control, frozen and recovered frogs as determined from western blotting. Histogram shows mean $\pm \mathrm{SEM}$, $\mathrm{n}=4$ independent determinations. * - Values for frozen or recovery samples were significantly different than the corresponding control values, $\mathrm{P}<0.05$. 
(A)

\section{Bcl-2}

$\begin{array}{lll}C & \mathbf{F} & \mathbf{R}\end{array}$

Liver

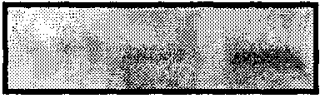

Muscle

Kidney

(C)

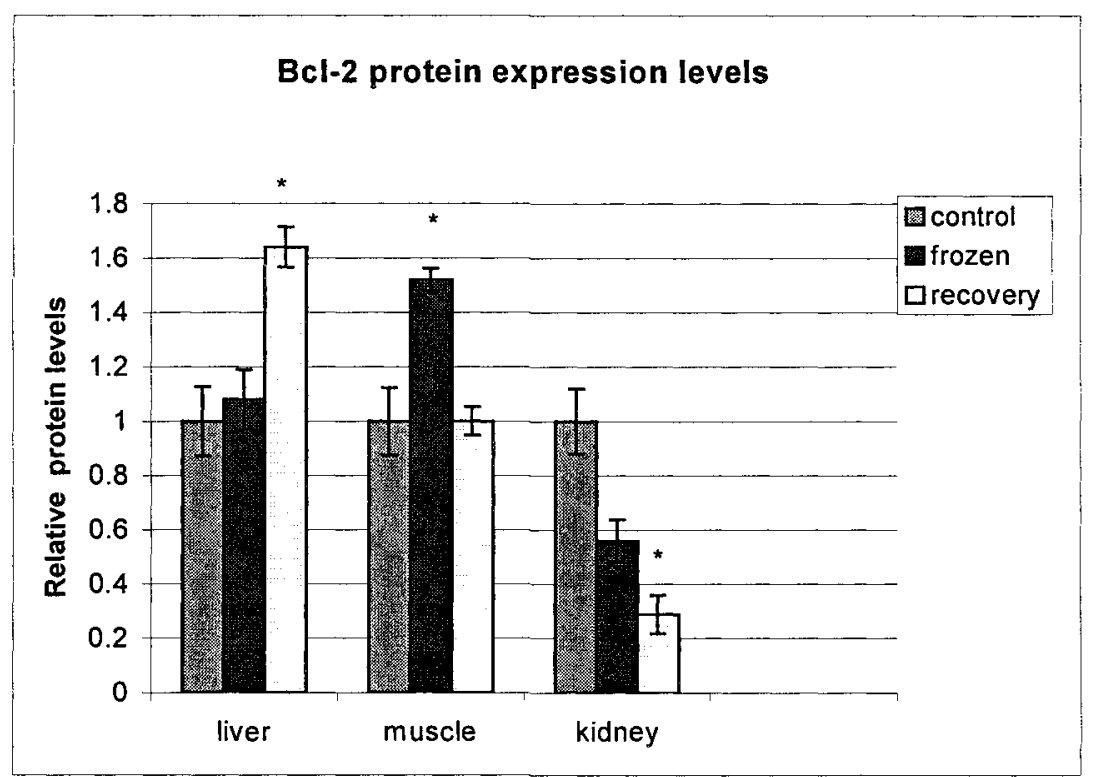

(B)

\section{Phospho-Bcl-2}

$\begin{array}{lll}\text { C } & \mathbf{F} & \mathbf{R}\end{array}$
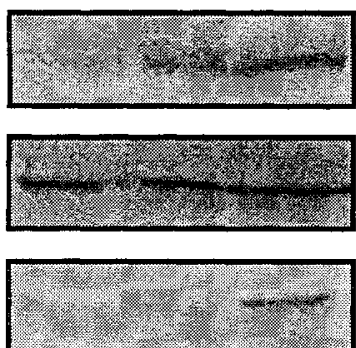

.

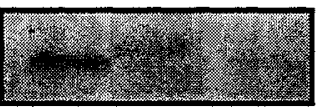

\section{)}

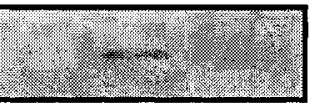

(D) . 


\section{Figure 2.7}

Western blots showing Bcl-xL protein content in tissues of liver, muscle and kidney from control, frozen and recovery samples.

(A) Representative Western blots showing Bcl-xL protein levels in liver, muscle and kidney from control (C), frozen (F) and thawed recovery (R) frogs.

(B) Relative Bcl-xL protein levels in tissues from frozen and thawed frogs versus control samples as determined from Western blotting. Histogram shows mean \pm SEM, $n=4$ independent determinations. $*$ - Values for frozen or recovery samples were significantly different than the corresponding control values, $\mathrm{P}<0.05$. 
(A)

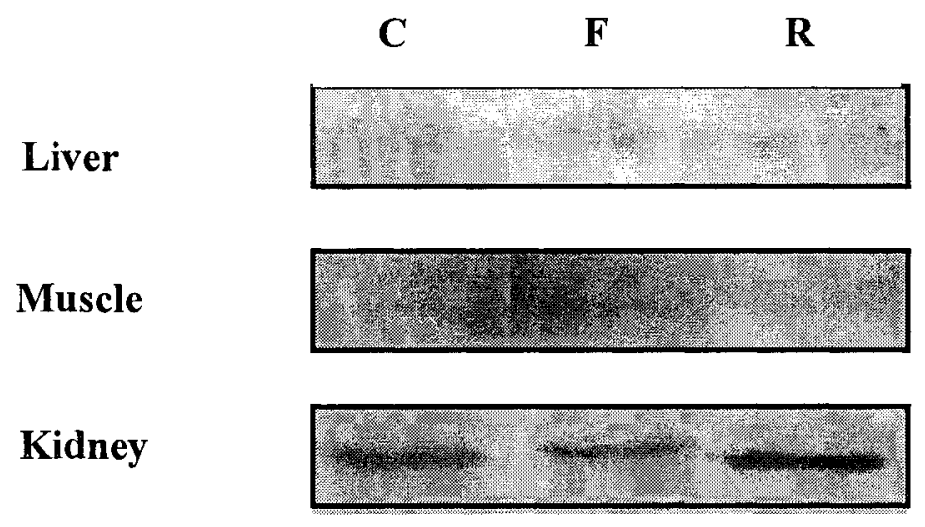

(B)

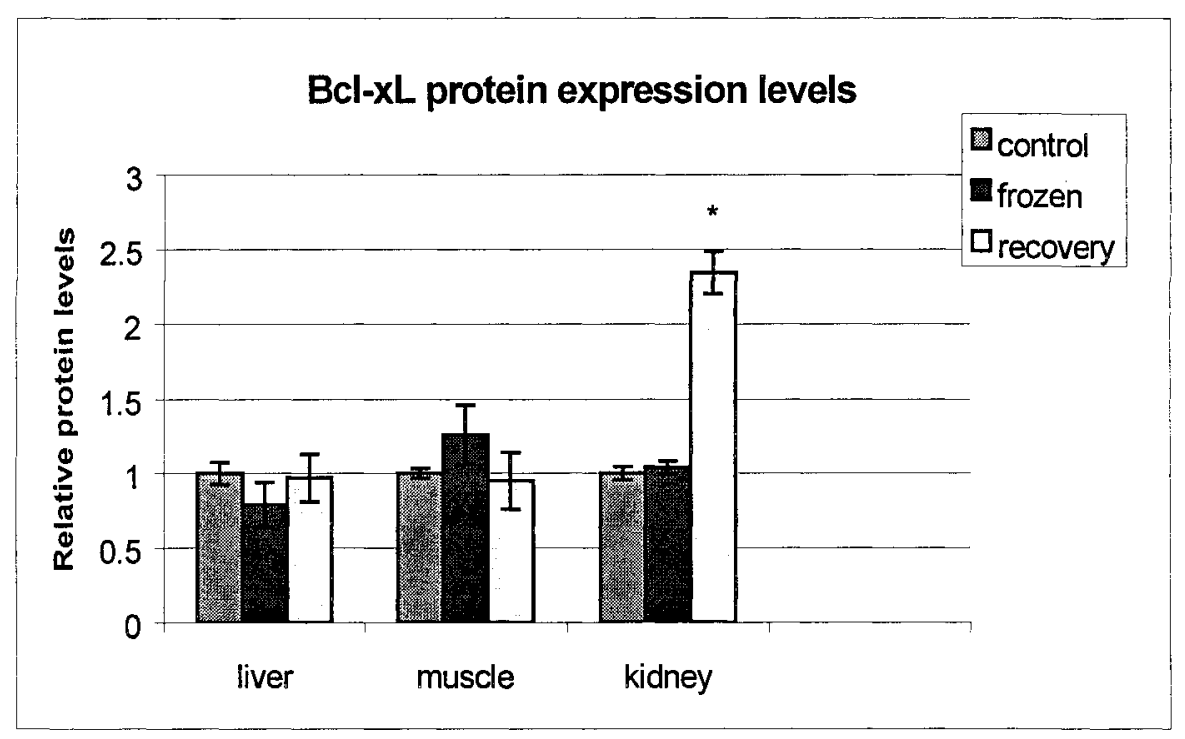




\section{Figure 2.8}

Western blots showing Bad and phospho-Bad (Ser112) protein contents in liver, muscle and kidney from control, frozen and thawed recovery frogs.

(A) Representative Western blots showing Bad content levels in control(C), frozen $(\mathrm{F})$ and thawed recovery $(\mathrm{R})$ frogs.

(B) Representative Western blots showing phospho-Bad (Ser112) content in control (C), frozen (F) and thawed recovery (R) frogs.

(C) Relative levels of Bad proteins in liver, muscle and kidney from control, frozen and recovery samples as determined from Western blotting. Histogram shows mean $\pm \mathrm{SEM}, \mathrm{n}=4$ independent determinations. * Values for frozen or recovery samples are significantly different than the corresponding control values, $\mathrm{P}<0.05$.

(D) Relative phospho-Bad (Ser112) protein levels in tissues from frozen and recovery samples versus control samples as determined from Western blotting. Histogram shows mean $\pm S E M, n=4$ independent determinations. * - Values are significantly different from the corresponding control values, $\mathrm{P}<0.05$. 
(A)

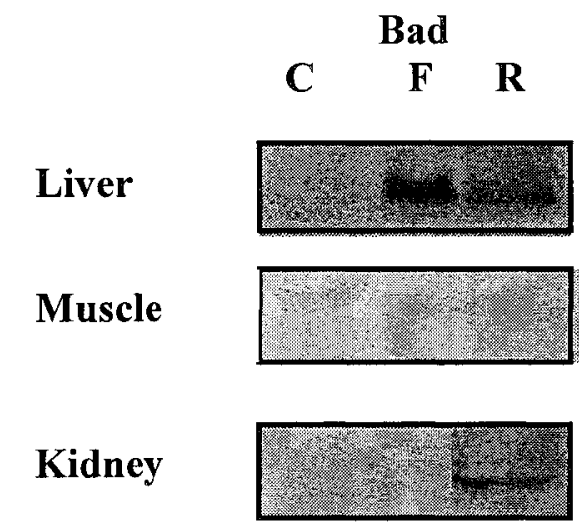

(B)
Phospho-Bad

C $\quad \mathbf{F} \quad \mathbf{R}$
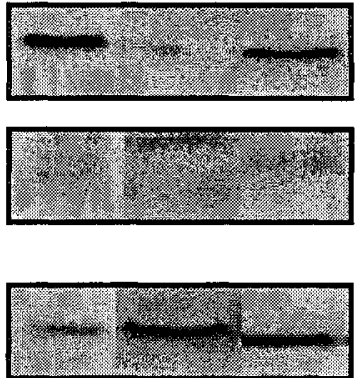

(C)

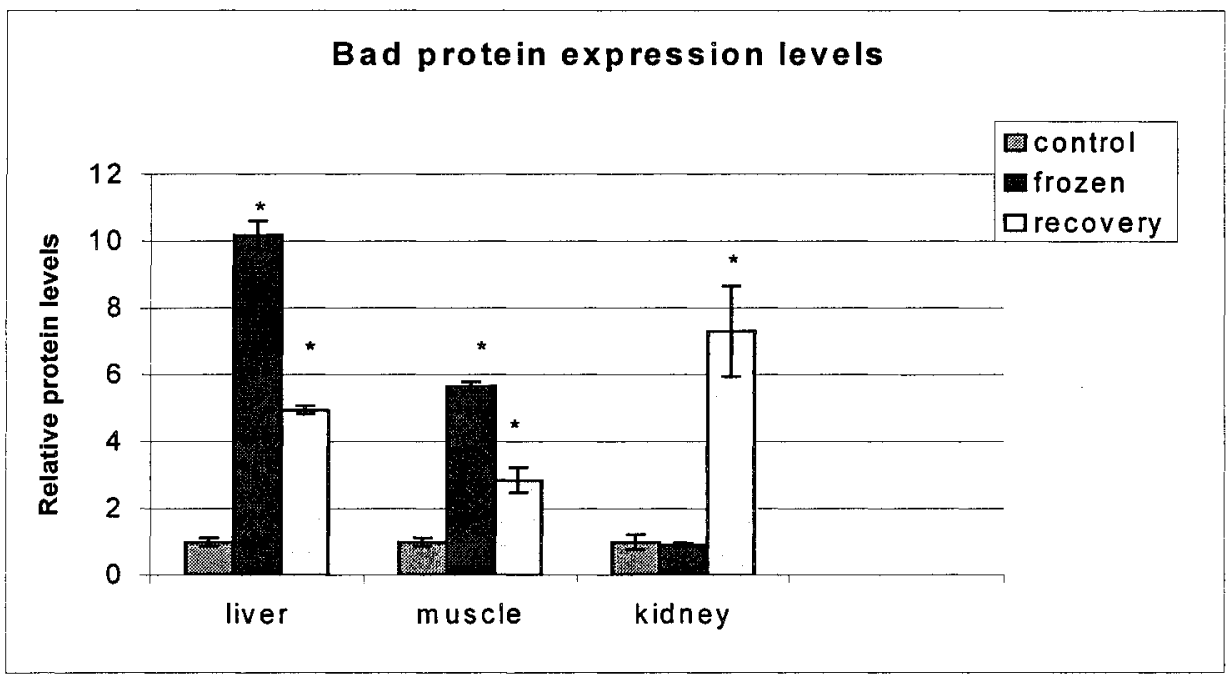

(D)

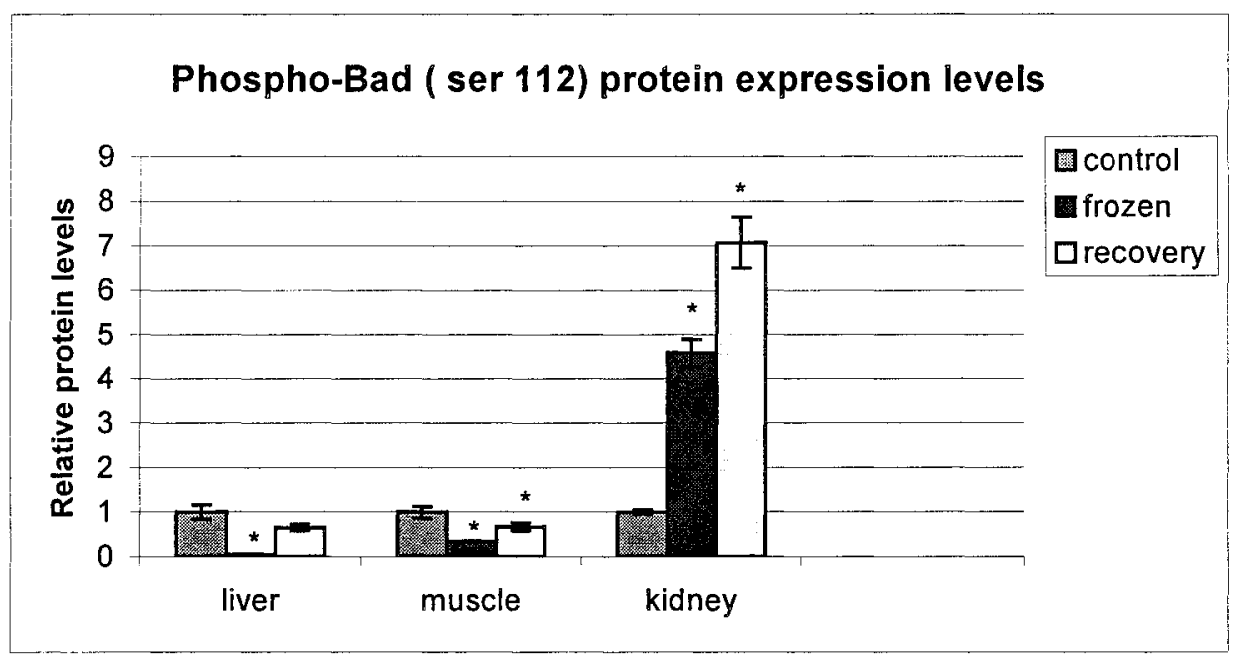




\section{Figure 2.9}

Analysis of DNA laddering in wood frog liver comparing control frogs (lanes 1 and 2), frozen frogs (lanes 3 and 4), and thawed frogs (lanes 5 and 6). A commercial DNA ladder was loaded into lane 7. 


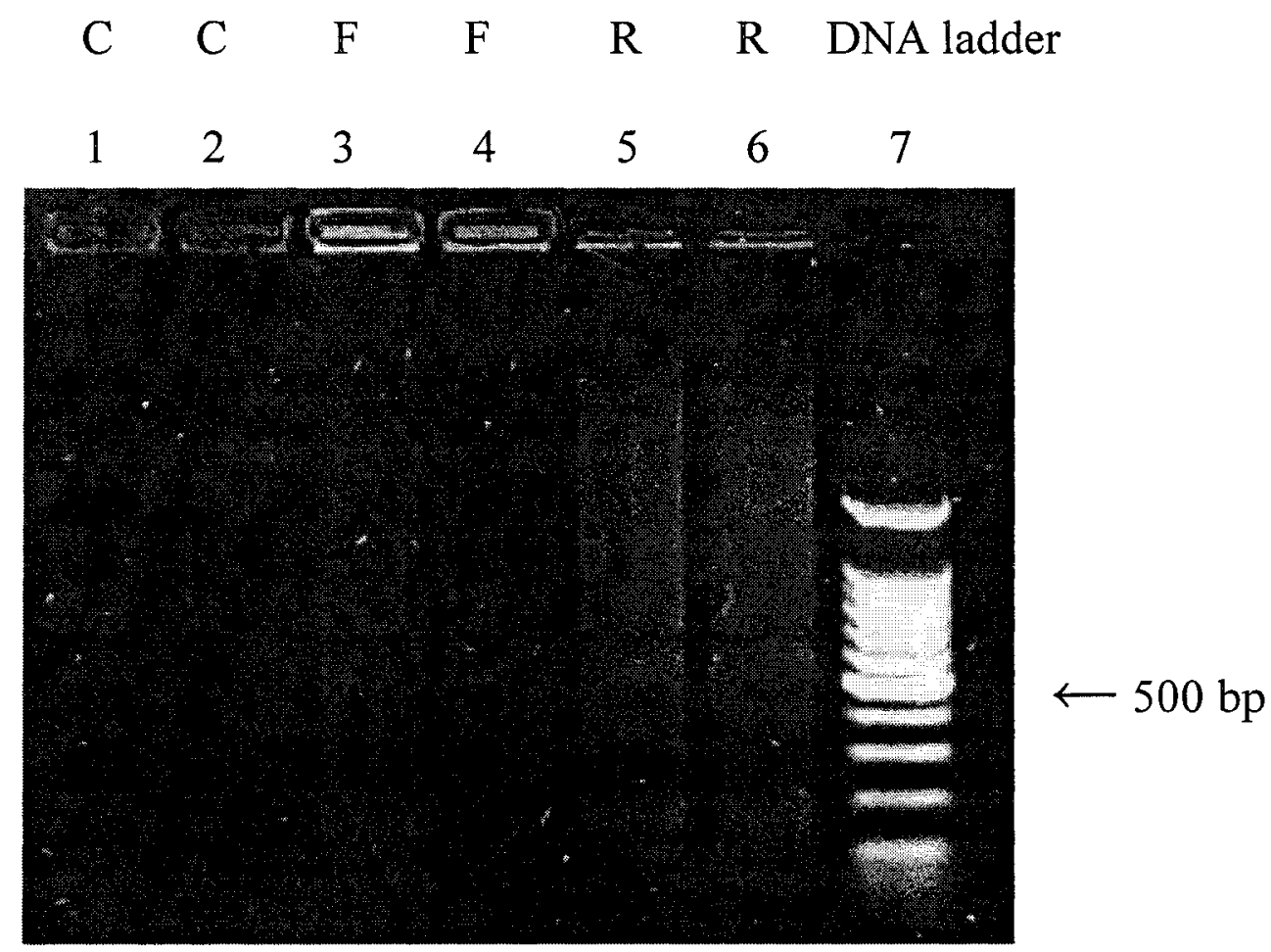




\subsection{Discussion}

A change in expression of some proteins associated with apoptosis was hypothesized to be involved in the freeze-thaw transition in wood frogs, Rana sylvatica. The current study makes an assessment of proteins that are associated with the suppression of apoptosis and the responses of these proteins to freeze-thaw stresses.

\subsubsection{Phospho-STATs}

In recent years, the fundamental roles of STATs in highly diverse biological processes are being increasingly recognized. It is now known that many cytokines, hormones and growth factors act through JAK-STAT signaling pathways in mammals to control a remarkable variety of biological responses including development, differentiation, cell proliferation and survival. Moreover, it was reported that ischemia/reperfusion injury could trigger this pathway (Bolli et al., 2003, Xuan et al., 2001) and Simon et al. (1998) demonstrated that reactive oxygen species (ROS) could activate the JAK-STAT pathway in mammalian cells. The wood frog survives stresses including freezing, ischaemia/reperfusion, anoxia, dehydration and oxidative damage during freeze/thaw cycles (Storey and Storey, 2004). Hence, I hypothesized that one or some of these stresses would activate the JAK-STAT pathways in wood frogs during freezing.

Each of the STATs has a conserved tyrosine residue at around 700 residues from the N-terminus, which is the substrate for phosphorylation (Leonard et al. 1998). Ligandactivated cytokine or growth factor receptors initiate STAT signal transduction either by the activation of the Janus Kinase (JAK) family of tyrosine kinases or via intrinsic 
receptor tyrosine kinase domains, which results in phosphorylation of tyrosine residues of STATs. Besides tyrosine phosphorylation in all STAT members, a serine phosphorylation site has been found in some STATs members, including Stat 1, Stat 3 and Stat5. Much research in the past few years has focused on the identification of the kinases that are responsible for Stat serine phosphorylation. However, these issues are far from resolved for individual Stat members. It has now been demonstrated that, depending on the cytokine and cellular setting, extracellular signal-regulated kinases (ERKs), c-Jun Nterminal kinases (JNKs) and p38 mitogen activated protein kinase (p38 MAPK) (p38) can be involved in mediating Stat1 and Stat3 serine phosphorylation. Following its phosphorylation, the STATs can form homodimers or heterodimers and migrate into the nucleus where they activate different genes (James et al., 1997).

In the current study, the relative amounts of phosphorylated Stat proteins were assessed in control $\left(5^{\circ} \mathrm{C}\right.$ acclimated), frozen $\left(24 \mathrm{~h}\right.$ at $\left.-2.5^{\circ} \mathrm{C}\right)$ and thawed $\left(8 \mathrm{~h}\right.$ at $5^{\circ} \mathrm{C}$ after $24 \mathrm{~h}$ frozen) wood frogs. The results for phospho-Stat5 (Tyr694) showed tissue-specific responses over the freeze/thaw process. The amount of phospho-Stat5 (Tyr694) increased strongly during thawing in kidney, skeletal muscle and skin and was also significantly elevated in skin during freezing. This suggests that genes regulated by Stat5 are upregulated when frogs thaw, probably mediating mechanisms that help organs to recover from the metabolic insults or injuries caused by freezing. For example, mechanisms of anti-apoptosis could be critical to allowing wood frog cells to recover from extreme stresses associated with long term freezing, such as prolonged ischemia and greatly reduced cell volume that could be near the critical minimum cell volume. More and more studies have indicated that Stat5 has a prominent anti-apoptotic role in mammalian cells 
(Kieslinger et al., 2000; Socolovsky et al., 2001; Snow et al., 2002). Among the downstream genes under control by Stat5 is $\mathrm{Bcl}-\mathrm{xL}$, which is an anti-apoptotic protein in cells (Silva et al., 1999; Gesbert and Griffin, 2000). One facet of natural freeze tolerance may be to block potential apoptotic signals arising due to ischemia or volume stressses and instead promote recovery/repair mechanisms that restore cell functions after thawing.

The increase in phospho-Stat5 (Tyr694) (Fig. 2.3) during thawing in muscle, kidney and skin means that thawing stimulated the phosphorylation of Stat5 at tyrosine 694 and, therefore, suggests that anti-apoptotic mechanisms are activated when the frogs melt, probably to help restore normal cell function. However, the results for liver showed the opposite response, a decrease in the relative amount of phosphorylated Stat5 (Tyr694). This suggests that Stat5 or phosphorylation of Stat5 on tyrosine 694 may have a different function in liver as compared with other organs in wood frogs. Notably, liver is a very well-protected organ in the frozen frog with the highest cryoprotectant levels of any organ (Storey and Storey, 2004) and liver also has a high regenerative capacity. Hence, it is possible that of all organs, freeze/thaw is the least stressful for liver (perhaps generating no apoptotic signals) or that liver, unlike most other organs, has the option of proliferating new cells to replace any that are damaged during freezing. How Stat5 responds in other tissues remains to be determined because other than the four tissues tested here, other tissues were harder to evaluate because of low phospho-Stat5 (Tyr694) levels and/or lack of antibody crossreaction.

Various metabolic and gene expression responses to freezing have been identified as being responses to one of the components of freezing stress such as oxygen deprivation or cellular dehydration (Storey and Storey, 2004). Often a metabolic/gene 
response to freezing is mimicked by exposure to anoxia $\left(\mathrm{N}_{2}\right.$ gas exposure) or dehydration (loss of $20-40 \%$ of total body water). For example, freeze-induced up-regulation of fibrinogen gene expression in wood frog liver is also triggered by dehydration (but not by anoxia) whereas up-regulation of the mitochondrial ADP-ATP translocase is triggered by anoxia exposure (Cai and Storey, 1997a; Cai et al., 1997). To determine whether Stat5 phosphorylation on Tyr694 is similarly responsive to either anoxia or dehydration stresses, phospho-Stat5 (Tyr694) levels were assessed in frogs given $24 \mathrm{~h}$ anoxia exposure or dehydrated to $40 \%$ of total body water lost. The data in Figure 2.4 (B) and (C) show rather different patterns of response to anoxia or dehydration stresses as compared with the responses to freezing seen in Figure 2.3. Stat5 phosphorylation was not influenced by dehydration/rehydration in liver, muscle or kidney which argues against cell water loss as a trigger for changes in phospho-Stat5 levels in these organs. However, the content of phospho-Stat5 (Tyr694) rose in skin of dehydrated animals, mimicking the comparable increase in skin during freezing. Skin was the organ to show significantly increased phospho-Stat5 (Tyr694) during freezing and the results of the dehydration and anoxia experiments suggest that this response may be triggered by the dehydration of skin cells during freezing. This is reasonable because skin of wood frogs is very sensitive to environment stresses such as changes in humidity and temperature (Wu, Ph.D thesis 1999). Kidney showed a rise in phospho-Stat5 (Tyr694) in response to aerobic recovery after anoxia which was similar to the increase in this organ during thawing. Muscle also showed a rise in phospho-Stat5 (Tyr694) content after anoxia (although anoxia itself suppressed phospho-Stat5 content). Hence, in muscle and kidney, the thaw-associated rise in phospho-Stat5 (Tyr694) might be linked with the recovery 
from anoxia/ischemia imposed by freezing. However, the responses to freeze/thaw by phospho-Stat5 (Tyr694) in liver were not comparable to the responses to either anoxia or dehydration which suggests that the suppression of phospho-Stat5 (Tyr694) in liver during freeze/thaw is triggered by a different factor. Therefore, the role that STAT5 plays in liver is more subtle and further experiments will be necessary to understand its function in this organ.

Stat1 is another important member of STAT family and studies indicate a broader role for Stat1 in cell death and survival. Some researchers have shown that Stat1 acts as a tumor suppressor (Lee et al., 2000; Kaplan et al., 1998). Other studies have demonstrated that Stat1 can induce apoptosis in mammalian cells (Stephanou, 2004; Sahni et al., 2001). Although phosphorylation of tyrosine 701 in Stat 1 was originally thought to be essential for Stat1 function, recent studies have shown that some genes can be induced by Stat1 in a tyrosine 701 independent manner or are responsive to phosphorylation on another site, for example, phospho-Stat1 (Ser727). Stephanou et al. (2003) reported that phosphoStat1 (Ser727) induced an autocrine death pathway by inducing expression of the Fas and FasL genes leading to apoptosis in cardiac myocytes exposed to ischaemia/reperfusion. In general, STAT1 possesses pro-apoptotic property (Battle and Frank, 2002), which is activated in response to some unique physiological/pathological stimuli, though the mechanistic basis for these effects is still unclear.

The present study only measured the content of phospho-Stat1 (Tyr701) in frog tissues comparing controls, $24 \mathrm{~h}$ frozen and $8 \mathrm{~h}$ thawed recovery (Fig. 2.5B). A response pattern similar to that seen for phospho-Stat 5 (Tyr694) was seen in skeletal muscle, kidney and liver whereas freeze/thaw had no effect on phospho-Stat1 (Tyr701) content in 
skin tissue. Like phospho-Stat 5, the content of phospho-Stat1 (Tyr701) was strongly reduced in liver during freezing and remained low during thawing. However, in kidney and skeletal muscle, phospho-Stat1 (Tyr701) increased strongly during recovery which indicates a potentially strong induction of genes that are regulated by Stat 1 during the recovery from freezing stress, such as some caspase genes, and Fas and FasL, which are pro-apoptotic regulatory genes (Battle and Frank, 2002).

Although some studies have demonstrated that Stat3 can also promote apoptosis, a growing body of literature supports the hypothesis that Stat 3 protects mammalian cells against apoptosis (Battle et al., 2002). Phospho-Stat3 (Ser727) could be quantified in wood frog liver and skin and in both cases increased substantially (by 2.3-2.6 fold) during freezing (Fig. 2.5C). Hence, it is possible that Stat3 activated anti-apoptotic proteins to protect cells during freezing in these two tissues. Phospho-Stat3 (Ser727) mediated antiapoptotic mechanisms may provide sufficient protection to liver during the freezing process such that this organ does not rely on Phospho-Stat5 (Tyr694) mediated antiapoptotic mechanisms.

Taken together, the present study supports a role for the JAK-STAT pathway in various forms of cellular stress in wood frogs. Consistent with some of the current ideas about STAT biology, it is clear that cellular stress seems to activate STATs in ways that can be both detrimental to and supportive of cell survival. For example, STAT1 activation by anoxia/reperfusion stress activates a cell death pathway, whereas STAT5 activation by the same type of stress seems to promote cell survival pathways. Thus, STATs may have evolved to fulfill both sides of a pro- and anti- apoptotic type 
mechanism where either death or survival pathways can be activated depending on the strength or type of cellular stress (Dudley et al., 2004).

\subsubsection{Bcl-2 Family Proteins}

A variety of physiological death signals and pathological cellular insults trigger the genetically programmed pathway of apoptosis (Vaux et al., 1999). Apoptosis manifests in two major execution programs downstream of the death signal: the caspase pathway and organelle dysfunction, of which mitochondrial dysfunction is the best characterized (Gross et al., 1999). Proteins in the Bcl-2 family reside upstream of irreversible cellular damage and focus much of their efforts at the level of mitochondria; as such, they play an important role in deciding whether a cell will live or die. Therefore, I proposed that modulation of proteins in this family could be expected in response to freeze/thaw in frog organs.

The amount of Bcl-2 protein and its relative phosphorylation state, as judged by phospho-Bcl-2 (Ser70) content, showed different patterns (Fig. 2.6) in the three organs tested (liver, skeletal muscle, kidney). In liver, phospho-Bcl-2 (Ser70) increased significantly during freezing whereas both the total amount of $\mathrm{Bcl}-2$ and the amount of the phosphoprotein increased when frogs were thawed. Total Bcl-2 levels rose in skeletal muscle during freezing but the amount of phosphoprotein increased during thawing. By contrast, the overall levels of $\mathrm{Bcl}-2$ decreased over the course of the freeze/thaw process in kidney but the phosphorylation state of the protein rose dramatically.

Over-expression of Bcl-2 enhances survival of mammalian cells in response to various stimuli (Mastrangelo et al., 2000; Singh et al., 1996, Figueroa et al., 2001.). 
Hence, in liver and skeletal muscle, upregulation of Bcl-2 possibly helped to protect frog cells from apoptosis during freeze/thaw. Recent studies have shown that phosphorylation of Bcl-2 is required for its anti-apoptotic function in mammalian cells (Ruvolo et al., 1998, Deng et al., 2001). Horiuchi et al. (1997) also reported that stimulation of the angiotensin II type 2 receptor in a rat pheochromocytoma cell line led to dephosphorylation of $\mathrm{Bcl}-2$ by activating mitogen-activated protein kinase phosphatase-1 and induced apoptosis. In the present study, the content of phospho-Bcl-2 (Ser70) increased significantly in skeletal muscle, liver and kidney tissues induced by freezing and/or thawing. This experiment shows that phosphorylation of $\mathrm{Bcl}-2$ at $\mathrm{Ser}^{70}$ may be necessary for full and potent anti-apoptotic function for the Bcl-2 protein.

$\mathrm{Bcl}-\mathrm{xL}$ is another important anti-apoptotic protein in the Bcl-2 family. Its expression is directly induced by STAT5 (Socolovsky et al., 1999; Gesbert and Griffin, 2000). Unlike the expression of $\mathrm{Bcl}-2$ protein, the level of $\mathrm{Bcl}-\mathrm{xL}$ was stable in liver and skeletal muscle over the freeze/thaw cycle, but it was up-regulated in kidney during thawing (Fig. 2.7). Hence, elevated Bcl-xL levels may play a role to protect kidney cells, rising during thawing to help prevent cells from undergoing apoptosis while repairs are made to overcome any freeze-induced damage. Elevated Bcl-xL levels in kidney of thawed animals may perhaps also compensate for the reduced levels of Bcl-2 in kidney of thawed frogs.

Bad is a pro-apoptotic molecule in the Bcl-2 family that plays a critical role in apoptosis. Its function is regulated by reversible phosphorylation on Ser112, 136 and 155 (Chen et al., 2005). Under normal conditions, phosphorylated Bad is sequestered in its inactive form in the cytosol through binding to protein 14-3-3. Following a death signal, 
such as ischaemia/reperfusion, Bad is dephosphorylated, dissociates from 14-3-3, and is targeted to the mitochondria, where it binds to integral membrane proteins such as $\mathrm{Bcl}-\mathrm{xL}$ and Bcl-2 (Chiang et al., 2003). With these anti-apoptotic proteins inactivated, cytochrome $C$ is released from mitochondria and a cascade of changes occurs leading to cell death (Green and Reed, 1998) (See figure 2.2).

For wood frogs, the content of Bad increased sharply in liver and skeletal muscle during freezing (Fig. 2.8C), and phospho-Bad (Ser112) decreased significantly (Fig. 2.8D), phospho-Bad (Ser 136) and phospho-Bad (Ser155) were not detected. Levels of dephosphorylated Bad increased greatly in liver and muscle and this would result in a translocation of Bad from the cytoplasm to mitochondria where it could bind to $\mathrm{Bcl}-\mathrm{xL}$ and $\mathrm{Bcl}-2$. Hence, these data provide strong evidence that freezing triggers apoptotic signals in cells, even though these are freeze tolerant animals. What must be critical in freeze tolerant animals, therefore, is that pro-apoptotic signals are either blocked, reversed or over-ridden by anti-apoptotic signals in order to achieve cell survival after thawing. We do not yet know if the actions of Bad or other pro-apoptotic signals are blocked in wood frog organs but a reversal of Bad effects apparently occurs after thawing since Bad protein levels fall and the amount of phospho-Bad rises again (Ser112). The data for $\mathrm{Bcl}-2$ proteins also indicate that anti-apoptotic responses are enhanced, especially during thawing. In kidney a different response was seen. The content of Bad was stable during freezing, but phospho-Bad (Ser112) rose significantly suggesting a net decrease in pro-apoptotic signaling from Bad at this time. Although total Bad protein levels rose sharply after thawing, so did phospho-Bad (Ser112) content which suggests that a high proportion of the protein is kept in an inactive state, presumably allowing anti-apoptosis 
signals to predominate during thawing. So, it is possible that no apoptosis or lower apoptosis was induced in kidney tissue during freeze/thaw.

\subsubsection{DNA laddering}

A hallmark of apoptosis is the observation that nuclear DNA extracted from apoptotic cells is often degraded in an internucleosomal pattern. That is, DNA cleavage during apoptosis occurs at sites between nucleosomes, protein-containing structures that occur in chromatin at 180-bp intervals. Based on the DNA laddering pattern (Figure 2.9), the present data suggest that apoptosis was induced by freeze/thaw in liver and that DNA damage accumulated, especially in the thawed samples where a distinct DNA laddering was seen. This is consistent with the evidence of pro-apoptotic signaling provided by the response of phospho-Bad to freezing in liver. However, since frogs readily survive freezing exposures, the degree of apoptosis occurring must be limited and must be reversible in wood frog tissues.

In a summary, apoptotic cell death is critical for the maintenance of tissue homeostasis in a healthy or unhealthy organism. The balance between pro- and antiapoptotic proteins can determine cellular fate. The current study presents an analysis of the responses to freeze/thaw by multiple parameters related to apoptosis in wood frogs. The data suggest that pro-apoptotic signals are generated during freezing but that wood frogs have evolved a set of anti-apoptotic mechanisms to block, reverse or override freeze-induced cell death signals. The mechanisms by which anti-apoptosis is mediated in frozen frogs requires more attention. Not only is anti-apoptosis a key part of natural freezing survival by wood frogs but the mechanisms used by natural systems could have 
important application to improve the outcomes of cell, tissue organ cryopreservation in medical and veterinary sciences. 


\title{
Chapter 3
}

\section{Glutathione $S$-Transferases and}

\author{
Antioxidant Defense
}




\subsection{Introduction}

Wood frogs, Rana sylvatica, have developed freeze tolerance to endure winter temperatures below $0^{\circ} \mathrm{C}$. They can survive for several weeks with $65-70 \%$ of total body water frozen as extracellular ice. To survive freezing, frogs must have defense against a variety of stresses including cold stress, anoxia/ischemia stress caused by plasma freezing, osmotic/dehydration stress caused by cell water moving into extracellular ice, and oxidative stress during thawing. Oxidative stress arises when the generation of reactive oxygen species (ROS) such as superoxide, hydrogen peroxide, hydroxyl radical, and peroxynitrite exceeds the capacity of endogenous antioxidant defense systems. The main cellular components susceptible to damage by free radicals are lipids (peroxidation of unsaturated fatty acids in membranes), proteins (denaturation), carbohydrates and nucleic acids (Blokhida et al., 2003). Studies in mammalian systems have linked a substantial portion of ischaemic damage not to the period of oxygen deprivation itself, but, rather, to the reperfusion phase, when oxygen is reintroduced. Reoxygenation results in a burst of oxyradical production that can temporarily overwhelm the antioxidant defenses of an organ and cause extensive damage to cellular macromolecules. Freezethaw is an ischaemia-reperfusion event that has the potential to cause oxidative damage to organs when heartbeat and breathing are restored during thawing (Storey and Storey, 2004). Studies with wood frogs in our lab have indicated that two strategies contribute to the defense against oxidative stress associated with freeze-thaw. The first is the maintenance of high constitutive activities of antioxidant enzymes such as superoxide dismutase (SOD), catalase, glutathione reductase and glutathione $S$-transferase in frog 
organs. The second one is selective changes to the activities of some enzymes in response to freezing (Storey and Storey, 2004).

The glutathione $S$-transferases (GSTs) are an important family of antioxidant enzymes that catalyze the nucleophilic addition of the thiol of reduced glutathione to a variety of electrophiles (Rushmore et al., 1993). GSTs are a family of multifunctional proteins that are widely distributed in nature and found in diverse species, including plants, insects, fish, birds and mammals. A number of cytosolic GST isoenzymes have been purified from mammalian tissues, and based on their primary structures are categorized into five families in mammals, designated as classes alpha, mu, pi, sigma, and theta (Forkert et al., 1999). The GSTs are composed of two subunits and exist as either homo-or heterodimeric proteins.

Induction of GSTs and other antioxidant enzymes such as SOD, NAD(P)H: quinone oxidoreductase-1 (NQO1) and heme oxygenase 1 (HO1), regulated at the level of gene transcription, is essential for manifestation of the enzyme's cytoprotective function. It is known that the antioxidant response element (ARE) is an enhancer sequence that mediates transcriptional activation of genes in cells exposed to oxidative stress (Nguyen et al., 2003). Transcriptional activation through this enhancer appears to be mediated by basic leucine zipper transcription factors such as nuclear factor-erythroid 2 related factor-2 (Nrf2) and small Maf proteins (Hayes and Mclellan 1999). The proposed pathway for transcription factor $\mathrm{Nrf} 2$ is shown in Figure 3.0. Under basal conditions, Nrf2-mediated transcription is turned off because of the inhibitory effect of Keap1, a cytoplasmic cysteine-rich protein bound to the actin cytoskeleton. Keap1 binds to Nrf2 and sequesters the molecule outside of the nuclei, preventing Nrf2 from 
activating target genes. Upon sensing oxidative or xenobiotic stresses, disruption of the cytoplasmic complex between Keap1 and Nrf2 (perhaps due to the oxidation of redoxsensitive cysteines within Keap1 and/or the phosphorylation of Nrf2) results in Nrf2 translocation into the nucleus (Motohashi et al., 2004). In the nucleus, Nrf2 forms a heterodimer with one member of the Maf protein family and binds to the ARE to activate downstream target genes transcription.

Based on the above information that wood frogs endure oxidative stress and that more ROS are produced during freeze/thaw, I hypothesized that expression of GST genes would be activated during the freeze/thaw process in order to help minimize stressinduced damage at the extremes of their normal physiology. Furthermore, I hypothesized that the ARE/Nrf2 pathway may be involved in the activation.

The current studies were designed to examine the regulation of gene and protein expression of GST isoenzymes in wood frog tissues. In order to assess whether GSTs are regulated via the ARE/Nrf2 pathway, the protein expression and translocation of $\mathrm{Nrf} 2$ and MafG were also investigated. 
Figure 3.0 Mechanism of ARE/Nrf2 pathway

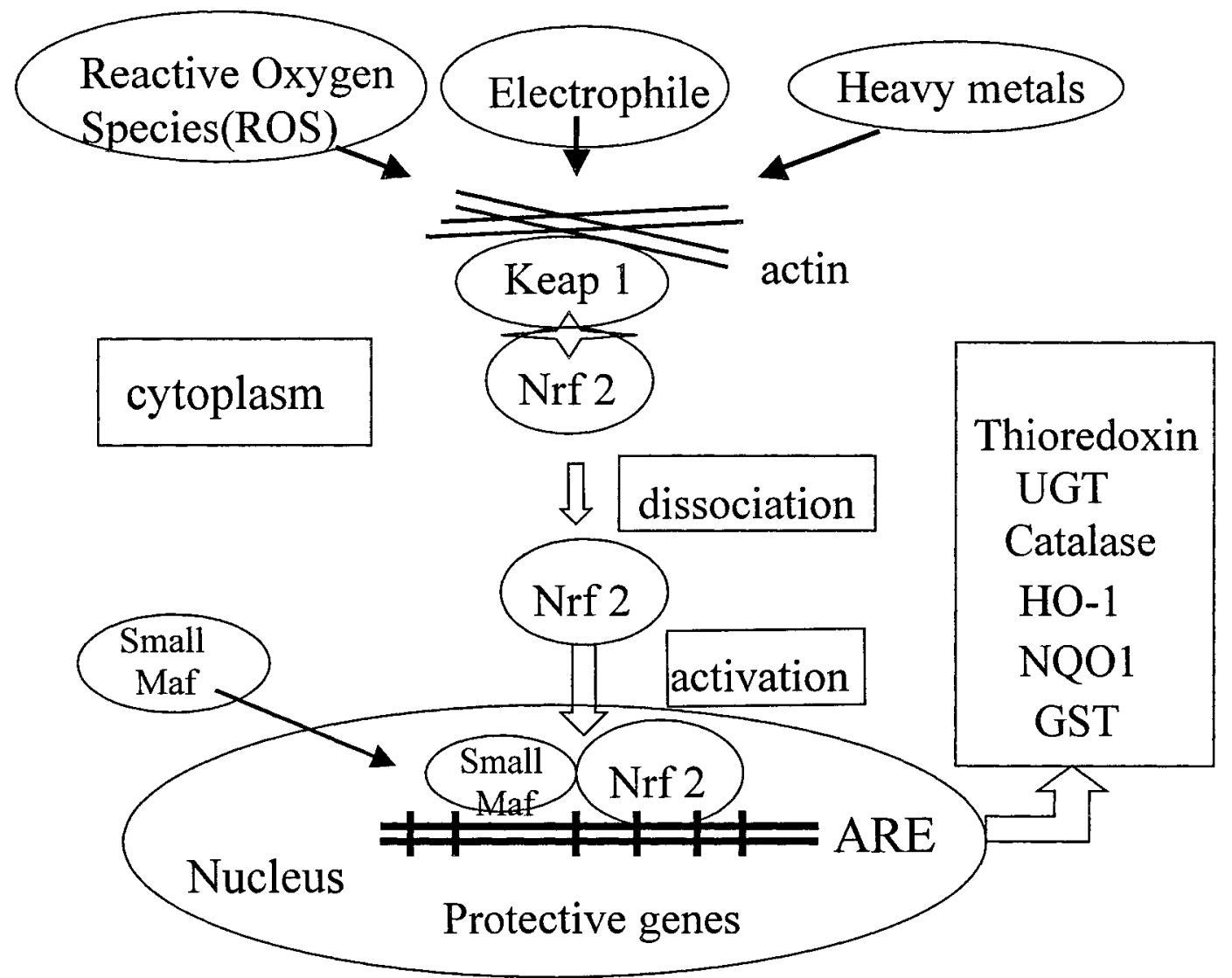




\subsection{Materials and methods}

\subsubsection{Animal experiments}

Animals were treated as previously described in Chapter 2.2.1.

\subsubsection{Western blotting}

Western blotting was used as previously described in Chapter 2.2.2; experimental conditions of western blotting are listed in Table 3.1, and antibodies used in Table 3.2. The following method was also used to isolate cytoplasmic and nuclear extracts from frozen tissues.

\section{Isolation of cytoplasmic and nuclear extracts from frozen tissues}

Frozen tissues were broken up with a mortar and pestle under liquid nitrogen. Samples were weighed $(0.5 \mathrm{~g})$ and added to $1 \mathrm{ml}$ of homogenization buffer containing 10 mM HEPES, pH 7.9, $10 \mathrm{mM} \mathrm{KCl,} 10 \mathrm{mM}$ EDTA, $1 \mathrm{mM}$ DTT and $10 \mu \mathrm{l}$ protease inhibitor cocktail (1 mM PMSF, 0.015\% w/v aprotimin, $10 \mu \mathrm{M}$ leupeptin, $1 \mu \mathrm{M}$ pepstatin, $1 \mathrm{mM} \mathrm{NaF}$ ). Samples were homogenized with 20 piston strokes using a Douce homogenizer and centrifuged at $10,000 \times \mathrm{g}$ for $10 \mathrm{~min}$ at $4^{\circ} \mathrm{C}$. The supernatant representing the cytoplasmic extract was removed into a sterile Eppendorf tube and stored in a freezer at $-80^{\circ} \mathrm{C}$. The pellet was resuspended in $150 \mu l$ of extraction buffer containing $20 \mathrm{mM}$ HEPES, pH 7.9, $0.4 \mathrm{M} \mathrm{NaCl}, 1 \mathrm{mM}$ EDTA, $10 \%$ v/v glycerol, 0.15 mM DTT and $1.5 \mu$ of protease inhibitor cocktail. This resuspension was held on ice and shaken for $1 \mathrm{~h}$ followed by centrifuging at $10,000 \mathrm{x}$ g for $10 \mathrm{~min}$ at $4^{\circ} \mathrm{C}$. The second supernatant was saved as the nuclear extract and stored at $-80^{\circ} \mathrm{C}$. Other procedures were as described in Chapter 2.2.2. 


\subsubsection{RT-PCR}

\subsubsection{RNA Preparation}

To avoid RNAase contamination, all solutions and materials used during RNA handling were treated overnight with $1 \%(\mathrm{v} / \mathrm{v})$ diethylpyrocarbonate (DEPC) at RT and later autoclaved. Samples of frozen tissues $(50-150 \mathrm{mg})$ were quickly weighed and placed in $2 \mathrm{ml}$ Eppendorf tubes, $1 \mathrm{ml}$ of Trizol ${ }^{\mathrm{TM}}$ reagent (Invitrogen) was added, and then samples were homogenized by a Polytron PT 1000 and allowed to sit for 2-3 min at RT. A $200 \mu \mathrm{l}$ aliquot of chloroform was added and mixed for 15 seconds. After a further 2-10 min incubation at RT, samples were centrifuged at $13,000 \times \mathrm{g}$ for $15 \mathrm{~min}$ at $4^{\circ} \mathrm{C}$. The supernatant was transferred to an autoclaved $1.5 \mathrm{ml}$ Eppendorf tube containing $800 \mu \mathrm{l}$ isopropanol. After gentle shaking, the RNA was precipitated at RT for $10 \mathrm{~min}$. The samples were centrifuged at $12,000 \mathrm{x}$ for $15 \mathrm{~min}$ to pellet the RNA, the supernatant was discarded, and $0.35 \mathrm{ml}$ of $70 \%$ ethanol was added to the pelleted RNA to remove the lingering chemicals in the tubes. After washing for $1.5 \mathrm{~min}$ at RT, the pellets were recentrifuged for $5 \mathrm{~min}$ at $12,000 \mathrm{xg}$ at $4^{\circ} \mathrm{C}$. The supernatant was discarded and the RNA pellet was air-dried at RT and then dissolved in $100 \mu \mathrm{l}$ DEPC-treated water. Aliquots of $20 \mu \mathrm{l}$ were transferred to other tubes and all were stored at $-80^{\circ} \mathrm{C}$ until use. RNA concentration in samples was quantified spectrophotometrically at $260 \mathrm{~nm}$ and $280 \mathrm{~nm}$; at $260 \mathrm{~nm}$, an optical density of 1.0 is equal to an RNA concentration of $40 \mu \mathrm{g} / \mathrm{ml}$. The ratio $\mathrm{A}_{260} / 280$ assesses RNA quality, a value of 1.6 or higher indicating high purity.

\subsubsection{Testing RNA purity}

RNA purity (and lack of genomic DNA contamination) was assessed by 
formaldehyde RNA agarose gel electrophoresis. The apparatus used (e.g. gel tray, comb) was treated with 3\% v:v hydrogen peroxide for $30 \mathrm{~min}$, then washed with DEPC-treated water and dried at RT. DEPC-treated pipette tips were all used in all cases. For $125 \mathrm{ml}$ gel preparation, $1.5 \mathrm{~g}$ agarose (GIBCO BRL) was melted in $107.5 \mathrm{ml}$ DEPC-treated water and then $12.5 \mathrm{ml}$ of $10 \mathrm{x}$ formaldehyde gel running buffer (FGRB) [containing $0.2 \mathrm{M} 3-$ $\mathrm{N}$-morpholino propanesulfonic acid (MOPS), $50 \mathrm{mM}$ sodium acetate, $10 \mathrm{mM}$ EDTA, $\mathrm{pH}$ 7.0 ] and $7 \mathrm{ml}$ of $37 \% \mathrm{v} / \mathrm{v}$ formaldehyde solution was added. The mixture was cooled to $50-60^{\circ} \mathrm{C}$ and then $1.5 \mu$ of ethidium bromide $(\mathrm{EtBr})$ solution was mixed and the gel was poured. After the gel solidified for 20-30 min, it was pre-run for 5-10 min at $70 \mathrm{~V}$ in $1 \mathrm{x}$ FGRB. RNA samples were prepared by mixing $20 \mu \mathrm{g}$ of total RNA with $21.5 \mu \mathrm{l}$ FGRB loading solution that contained $12.5 \mu$ f formamide solution, $2.5 \mu 110 \times$ MOPS buffer (1 M MOPS, $0.1 \mathrm{M}$ sodium acetate and $1 \mathrm{mM}$ EDTA, $\mathrm{pH} 7.0$ ), $4 \mu \mathrm{l}$ of $37 \%$ formaldehyde, and $2.5 \mu \mathrm{l}$ of $10 \mathrm{x}$ RNA loading buffer $(0.9 \mathrm{ml}$ of $50 \% \mathrm{v} / \mathrm{v}$ glycerol, $2 \mu 1$ of $0.5 \mathrm{M}$ EDTA, $\mathrm{pH} 8.0,50 \mu \mathrm{l}$ of $0.25 \% \mathrm{w} / \mathrm{v}$ bromophenol blue, $50 \mu \mathrm{l}$ of $0.25 \%$ xylene cyanol FF) in a 0.5 $\mathrm{ml}$ RNAase-free Eppendorf tube. The mixture was heated for $5 \mathrm{~min}$ at $65^{\circ} \mathrm{C}$, coldsnapped on ice for $5 \mathrm{~min}$, quickly centrifuged, and then loaded onto the gel. In some cases a $7 \mu \mathrm{g}$ aliquot of RNA ladder was also loaded in one lane as a size marker. The gel was run at $70 \mathrm{~V}$ for $1 \mathrm{~h}$ until the blue dye migrated $5 \mathrm{~cm}$ away from the gel wells. The gel was photographed under a UV light transilluminator or using the SynGene. High quality of RNA was assessed by the presence of sharp and distinct $28 \mathrm{~S}$ and $18 \mathrm{~S}$ rRNA bands.

\subsubsection{Gene specific primer design and sequencing}

Oligonucleotide primers were designed and synthesized for the GST pi gene. 
Primer design began with the retrieval of nucleotide sequences for the gene of interest from the NCBI Genbank for other species, as closely related to frogs as possible. Human, mouse and African clawed frog (Xenopus laevis) (Genbank accession numbers: NM_000852, NM_181796 and AJ489617, respectively) GST pi mRNA sequences were chosen. The sequences were imported into DNAMAN 4.11 (Lynnon Biosoft) and a multiple sequence alignment was used to find highly conserved regions and generate one or more consensus sequences that could be used for primer design. Consensus sequences were imported into Primer Designer (Scientific and Educational Software) and used to generate both forward and reverse gene-specific primers. The forward and reverse primers designed for GST pi were 5'CCTCA/GG/TTTTCAGGATGGAGAC-3' and 5'AGATCTTCCACGCCATCA/GTT-3', respectively. These primers were expected to retrieve an approximately $140 \mathrm{bp}$ cDNA sequence from wood frog tissues. Amplification of alpha-tubulin was used to standardize the expression of the gene of interest. The tubulin primers were: forward 5'-AAGGAAGATGCTGCCAATAA-3' and reverse 5'GGTCACATTTCACCATCTG-3'. These primers were expected to retrieve an approximately 616 bp cDNA sequence from wood frog tissues. Primers were synthesized by Sigma Genosys and were aliquoted into $300 \mathrm{pmol} / \mu \mathrm{l}$ stocks in DEPC-treated water and stored at $-20^{\circ} \mathrm{C}$.

For first strand cDNA synthesis, a $10 \mu$ l volume containing $10-15 \mu l$ total RNA was mixed with $1 \mu \mathrm{l}$ of $200 \mathrm{ng} / \mu \mathrm{l}$ oligo-dT (Sigma Genosys). The mixture was incubated at $68^{\circ} \mathrm{C}$ in a water bath for $5 \mathrm{~min}$ to denature secondary structure, and then chilled quickly on ice for $5 \mathrm{~min}$. To obtain cDNA:mRNA hybrid, $4 \mu \mathrm{l}$ X first strand buffer (Invitrogen), $2 \mu \mathrm{l} 10 \mathrm{mM}$ DTT (Invitrogen), $1 \mu \mathrm{dNTPs}$ (Invitrogen) and $1 \mu \mathrm{l}$ superscript 
reverse transcriptase $(200 \mathrm{U} / \mu \mathrm{l})$ were added into the tube. This $19 \mu \mathrm{l}$ final volume was incubated at $40^{\circ} \mathrm{C}$ for $45 \mathrm{~min}$ and then stored at $4^{\circ} \mathrm{C}$.

\subsubsection{Quantifying cDNA:mRNA hybrid by RT-PCR}

Reverse transcription polymerase chain reaction (RT-PCR) was used to amplify cDNA and quantify the relative levels of selected mRNA species in tissue extracts of control versus experimental frogs. A $5 \mu$ l aliquot of first strand cDNA product was mixed with $95 \mu \mathrm{l}$ DEPC-treated water to produce a $10^{-1}$ dilution; this procedure was then repeated to obtain serial dilutions of $10^{-2}, 10^{-3}, 10^{-4}$ and $10^{-5}$. Each PCR reaction was carried out in a final volume of $26.875 \mu$, including $15 \mu \mathrm{H}_{2} \mathrm{O}, 5 \mu \mathrm{l}$ of serial of diluted cDNA, $2.5 \mu \mathrm{l} 10 \times \mathrm{PCR}$ buffer $\left(-\mathrm{MgCl}_{2}\right)$ (Invitrogen), $1.25 \mu \mathrm{l}$ of $50 \mathrm{mM} \mathrm{MgCl}_{2}$ (Invitrogen), $0.5 \mu \mathrm{l} 10 \mathrm{mM}$ DNTPs (Invitrogen), $0.125 \mu \mathrm{l}$ Taq DNA polymerase (Invitrogen) and $2.5 \mu \mathrm{l} 30 \mathrm{nmol} / \mathrm{ml}$ forward and reverse primer mixture (1:1). After mixing well and a quick spin, PCR reactions were performed in the thermocycler with the following steps: (a) $95^{\circ} \mathrm{C}$ pre-heat for $3 \mathrm{~min}$, (b) 37 cycles of running: $95^{\circ} \mathrm{C}$ for $30 \mathrm{sec}$ (denaturation), $50^{\circ} \mathrm{C}$ for $30 \mathrm{sec}$ (annealing) and $72^{\circ} \mathrm{C}$ for $30 \mathrm{sec}$ (elongation), and (c) final elongation at $72^{\circ} \mathrm{C}$ for $7 \mathrm{~min}$ and hold at $22^{\circ} \mathrm{C}$.

PCR products were mixed with DNA loading buffer containing $40 \%$ (w/v) sucrose, $0.25 \%(\mathrm{w} / \mathrm{v})$ bromophenol blue and $0.25 \%(\mathrm{w} / \mathrm{v})$ xylene cyanol FF. Samples were loaded onto $1.5 \%$ agarose TAE gel $(1.5 \% \mathrm{w} / \mathrm{v}$ agarose, $40 \mathrm{mM}$ Tris-acetate, $1 \mathrm{mM}$ EDTA, $\mathrm{pH}$ 8.3, $0.0005 \% \mathrm{v} / \mathrm{v}$ EtBr) with $1 \%$ TAE running buffer (40 $\mathrm{mM}$ Tris-acetate, $1 \mathrm{mM}$ EDTA, $\mathrm{pH} 8.3$ ) and separated by electrophoresis at $130 \mathrm{~V}$ in the 22 -well gel tray for $45 \mathrm{~min}$. DNA was visualized using the UV transilluimator function of the SynGene and band 
intensities were analyzed with the GeneTools program.

To compare PCR product levels of target genes between control and experimental states, confirmation that the starting samples contained equal amounts of mRNA is needed. This is provided by running parallel RT-PCR reactions using primers of a housekeeping gene (alpha-tubulin). Analysis of tubulin band intensities was used to normalize the band intensities of the PCR product of the gene of interest. The band intensities of stressed samples were expressed relatively to that of the control samples. The following equation was used: $W=\left(\left[E_{p}\right] /\left[E_{t}\right]\right) /\left(\left[C_{p}\right] /[C t]\right)$, where $\left[E_{p}\right]$ is the band intensity of PCR products of GST pi in stressed samples; [ $\left.\mathrm{E}_{\mathrm{t}}\right]$ is the band intensity of PCR products of alpha-tubulin of stressed samples; $\left[C_{p}\right]$ is the band intensity of PCR products of GST pi control samples, and $\left[\mathrm{C}_{\mathrm{t}}\right]$ is the band intensity of PCR products of alpha-tubulin of control samples. If $\mathrm{W}>1$ and the Student's t-test shows a significant difference between normalized experimental and control samples at $\mathrm{P}<0.05$, then upregulation of GST pi is indicated; down-regulation is indicated by $\mathrm{W}<1$ and $\mathrm{P}<0.05$.

PCR products were sequenced to confirm that they encoded the target gene. Automated sequencing was performed by Canadian Molecular Research Services (Orleans, ON, Canada) using the dideoxy method. The sequence was verified as the sequence expected via the program BLASTN (http://www.ncbi.nlm.nih.gov/blast) at the National Institutes of Health, Bethesda, MD. Deduced amino acid sequence of GST pi was analyzed by BLASTP to determine its percent identity compared to the sequences from other animals. 
Table 3.1 Experimental Conditions of Western Blotting

$\left.\begin{array}{|l|l|l|l|l|}\hline \text { Proteins } & \begin{array}{l}\text { Percent } \\ \text { Acrylamide } \\ \text { in Gel }\end{array} & \begin{array}{l}\text { Amount of } \\ \text { protein loaded } \\ \text { into wells }(\boldsymbol{\mu g})\end{array} & \begin{array}{l}\text { Time of } \\ \text { blocking with } \\ \mathbf{2 . 5 \%} \text { milk (min) }\end{array} & \begin{array}{l}\text { Time of incubation } \\ \text { with primary } \\ \text { antibodies (at 4 }\end{array} \\ \hline \text { GST Pi }\end{array}\right)$


Table 3.2 Antibodies Used in Western Blotting

\begin{tabular}{|c|c|c|c|}
\hline Proteins & $\begin{array}{l}\text { Primary antibodies } \\
\text { and dilutions (v:v) }\end{array}$ & $\begin{array}{l}\text { Secondary antibodies } \\
\text { and dilutions (v:v) }\end{array}$ & Sources \\
\hline GST Pi & $\begin{array}{l}\text { Rabbit anti-GST Pi } \\
\text { polyclonal antibody } \\
(1: 1000)\end{array}$ & $\begin{array}{l}\text { Anti-rabbit IgG HRP- } \\
\text { linked antibody } \\
(1: 2000)\end{array}$ & $\begin{array}{l}\text { Gift from Dr. } \\
\text { John Hayes, } \\
\text { University of } \\
\text { Dundee }\end{array}$ \\
\hline GST M1/2 & $\begin{array}{c}\text { Rabbit anti-GST M1/2 } \\
\text { polyclonal antibody } \\
(1: 1000)\end{array}$ & $\begin{array}{c}\text { Anti-rabbit IgG HRP- } \\
\text { linked antibody } \\
(1: 2000)\end{array}$ & Same as above \\
\hline GST A5 & $\begin{array}{l}\text { Rabbit anti-GST A5 } \\
\text { polyclonal antibody } \\
(1: 1000)\end{array}$ & $\begin{array}{l}\text { Anti-rabbit IgG HRP- } \\
\text { linked antibody } \\
(1: 2000)\end{array}$ & Same as above \\
\hline GST A3 & $\begin{array}{l}\text { Rabbit anti-GST A3 } \\
\text { polyclonal antibody } \\
(1: 1000)\end{array}$ & $\begin{array}{c}\text { Anti-rabbit IgG HRP- } \\
\text { linked antibody } \\
(1: 2000)\end{array}$ & Same as above \\
\hline GST M5 & $\begin{array}{c}\text { Rabbit anti-GST M5 } \\
\text { polyclonal antibody } \\
(1: 1000)\end{array}$ & $\begin{array}{l}\text { Anti-rabbit IgG HRP- } \\
\text { linked antibody } \\
(1: 2000)\end{array}$ & Same as above \\
\hline Nrf2 & $\begin{array}{c}\text { Rabbit anti-Nrf2 } \\
\text { polyclonal antibody } \\
(1: 1000)\end{array}$ & $\begin{array}{c}\text { Anti-rabbit IgG HRP- } \\
\text { linked antibody } \\
(1: 2000)\end{array}$ & $\begin{array}{c}\text { Gift from Dr. } \\
\text { Hayes and } \\
\text { SantaCruz } \\
\text { Biotechnology, } \\
\text { Santa Cruz, CA }\end{array}$ \\
\hline MafG & $\begin{array}{c}\text { Rabbit anti-MafG } \\
\text { polyclonal antibody } \\
(1: 1000)\end{array}$ & $\begin{array}{c}\text { Anti-rabbit IgG HRP- } \\
\text { linked antibody } \\
(1: 2000)\end{array}$ & Same as above \\
\hline
\end{tabular}




\subsection{Results}

\subsubsection{Analysis of GST Pi sequences}

The PCR products derived using GST Pi specific primers were sequenced and compared to the Genbank database located on the National Center for Biotechnology Information website. The nucleotide and deduced amino acid sequences are shown in Figure 3.1, and a comparison of nucleotide sequences with African clawed frog, house mouse and human GST Pi is shown in Figure $3.2(\mathrm{~A})$. The $R$. sylvatica GST Pi sequence that was retrieved from liver contained 142 nucleotides which is approximately $18-22 \%$ of the full size sequence of 639,785 and 737 nucleotides in clawed frog, mouse and human, respectively. The homology tree in Figure 3.2 (B) shows that wood frog GST Pi shares $66 \%$ nucleotide identity with human and mouse sequences and $60 \%$ identity with the clawed frog.

The segment of GST Pi retrieved from wood frog liver encoded 46 amino acids. This represents $\sim 22 \%$ of the protein sequence of 212,210 , and 210 amino acids in clawed frog, mouse and human, respectively. An alignment of its sequence with the three other species is shown in Figure $3.3(\mathrm{~A})$. The homology tree shows that $R$. sylvatica GST Pi amino acid sequence shared $57 \%$ identity with the other three animals (Figure $3.3 \mathrm{~B}$ ).

\subsubsection{Western blotting analysis of GST Pi expression in tissues}

Western blotting was used to assess the levels of GST Pi protein in tissues from wood frogs comparing $15^{\circ} \mathrm{C}$ acclimated controls with frogs frozen for $24 \mathrm{~h}$ at $-2.5^{\circ} \mathrm{C}$ and frogs thawed at $5^{\circ} \mathrm{C}$ for $8 \mathrm{~h}$ after $24 \mathrm{~h}$ frozen. The anti-GST Pi polyclonal antibody crossreacted with a single band on the gels at a molecular weight of $\sim 30 \mathrm{kDa}$, which is typical 
for GST Pi enzymes. Figure 3.4(A) shows a full blot $(\mathrm{n}=3$ independent samples from kidney for each condition) with a protein standard lane whereas Figure 3.4(B) shows an example for each tissue ( $\mathrm{n}=1$ for each condition). Data for multiple trials are summarized in the histogram (Figure $3.4 \mathrm{C}$ ). In brain, the level of GST Pi increased significantly $(\mathrm{P}<0.05)$ by 4.6 -fold during freezing and rose further to 9.1 -fold $(\mathrm{P}<0.05)$ above the control level after thawing. A similar situation was seen in gut, liver and skeletal muscle; GST Pi levels increased significantly $(\mathrm{P}<0.05)$ in these tissues during freezing by 3.3fold, 1.9-fold and 4.3-fold, respectively. Although GST Pi protein levels decreased after thawing compared with values in the frozen state, levels were still elevated significantly $(\mathrm{P}<0.05)$ by 1.8 -fold and 2.5 -fold in gut and skeletal muscle, respectively, as compared with the corresponding control levels. For liver, the protein content returned to control levels after thawing. By contrast, the GST Pi content decreased in heart during freezing and fell even further by $70 \%(\mathrm{P}<0.05)$ after thawing, as compared with controls. In kidney, the levels of the protein were stable during freeze-thaw.

\subsubsection{Analysis of GST Pi transcription in frog tissues}

The effect of $24 \mathrm{~h}$ freezing and $8 \mathrm{~h}$ thawing on GST Pi transcript levels was determined by relative quantitative RT-PCR. This technique involves amplifying an internal control simultaneously with the gene of interest. The internal control is used to normalize the samples. Once cDNA levels are normalized, direct comparisons of GST Pi mRNA levels can be made across the samples. Figure 3.5 (A) shows an example of the results obtained; PCR was conducted using 5 dilutions of cDNA prepared from liver mRNA of control, frozen and thawed frogs using either GST Pi primers or alpha-tubulin 
primers. Figure 3.5 (B) shows the results from quantifying the bands for the $10^{-4}$ dilution for four independent trials in six wood frog organs. Transcript levels increased significantly $(\mathrm{P}<0.05)$ during freezing in liver by 2.5 -fold; this is consistent with the increased protein expression. Transcript levels decreased again and returned to control levels after thawing. Transcripts were stable in other tissues during freeze-thaw.

\subsubsection{Analysis of GST M1/2 protein expression in frog tissues}

Western blotting was also performed to assess the responses of other isoforms of GST to freeze-thaw. Figure 3.6 shows the results for GST M1/2 protein contents in six tissues of wood frogs. In brain, skeletal muscle and skin, the GST M1/2 protein content did not change over the course of freeze-thaw. However, in gut, protein levels increased significantly $(\mathrm{P}<0.05)$ by 3.0 -fold during freezing and remained 2.4 -fold higher than control levels after thawing. Freezing did not affect the protein content in liver, but levels decreased significantly $(\mathrm{P}<0.05)$ by $46 \%$ below control values after thawing. For kidney, GST M1/2 content decreased significantly $(\mathrm{P}<0.05)$ by $30 \%$ during freeze-thaw.

\subsubsection{Western blotting analysis of GST A5 protein expression}

The effects of freeze/thaw on the protein level of GST A5 in frog tissues were also examined via western blotting (Figure 3.7). The levels of GST A5 protein increased significantly $(\mathrm{P}<0.05)$ by 1.9 -fold and 3.9 -fold, respectively, during freezing and after thawing in liver. In muscle, protein content also increased significantly $(\mathrm{P}<0.05)$ by 2.7 fold during freezing, but returned to control levels after thawing. No GST A5 protein was detected in the other frog tissue tested with the anti-GST A5 antibody used. A possible 
reason is that the concentration of GST A5 in these tissues could be very low.

\subsubsection{Analysis of GST M5 and GST A3 protein expression}

Western blotting was also used to measure the GST M5 and GST A3 protein contents in frog tissues (Figure 3.8). GST M5 protein levels increased by 1.5 -fold $(\mathrm{P}<0.05)$ in skeletal muscle during freezing and continued to increase during thawing, reaching 5.5-fold higher than controls $(\mathrm{P}<0.05)$ after 8 hours thawed. The M5 isozyme was not expressed in other tissues of wood frogs.

GST A3 protein levels decreased significantly by $50 \%(\mathrm{P}<0.05)$ in liver during freezing but returned to control levels after thawing. No GST A3 protein was detected in other tissues of wood frogs.

\subsubsection{Analysis of transcription factor Nrf2 protein expression}

Induction of GST, regulated at the level of gene transcription, is essential for its

cytoprotective function. A common mechanism of GST gene regulation is activation of transcription via the antioxidant response element (ARE) in response to the Nrf2 transcription factor pathway (Alam et al., 1999, Owuor et al., 2002). Western blots to detect Nrf2 showed two distinct bands, one band at $\sim 40 \mathrm{kDa}$ molecular weight and the other at $\sim 82 \mathrm{kDa}$ molecular weight. Figure 3.9 (A) shows an example of a full blot for brain samples ( $\mathrm{n}=4$ independent samples from each condition) with protein molecular weight markers. When the blocking peptide for Nrf2 antibody was used, both of these bands disappeared. Therefore, it appears that $\mathrm{Nrf} 2$ exists in two forms in wood frog organs. The $\sim 40 \mathrm{kDa}$ band appears to represent $\mathrm{Nrf} 2$ alone whereas the other band may 
result from covalent binding of $\mathrm{Nrf} 2$ with another protein resulting in al molecular weight for the complex of $\sim 82 \mathrm{kDa}$. Previous studies suggest that Nrf2 binds with actin in mammalian cells (Kang et al., 2002).

Western blotting analysis of Nrf2 in wood frog tissues revealed that the content of the $40 \mathrm{kDa} \mathrm{Nrf} 2$ protein increased significantly $(\mathrm{P}<0.05)$ in some tissues during freezing (Figure 3.9); levels rose by 1.4-fold in skin, 1.4-fold in liver, and 2.0-fold in skeletal muscle. After thawing, protein decreased to control levels in skin, but the content of 40 $\mathrm{kDa}$ Nrf2 remained 1.4-fold higher than the control in muscle. However, Nrf2 protein levels decreased by $36 \%$ in liver after thawing. Freezing did not effect the content of 40 $\mathrm{kDa} \mathrm{Nrf2}$ in brain, but the protein level increased significantly $(\mathrm{P}<0.05)$ by 1.7 -fold after thawing. The $40 \mathrm{kDa} N r f 2$ content decreased significantly $(\mathrm{P}<0.05)$ by $43 \%$ in gut during freezing, and then returned to control levels after thawing.

The content of $82 \mathrm{kDa} \mathrm{Nrf2}$ in frog tissues is shown in Figure 3.10. In skeletal muscle, the content of $82 \mathrm{kDa}$ Nrf2 behaved oppositely to the situation seen for $40 \mathrm{kDa}$ Nrf2 (Figure 3.9). Muscle $82 \mathrm{kDa}$ Nrf2 content decreased significantly $(\mathrm{P}<0.05)$ by $57 \%$ during freezing, and remained at a low level after thawing. Oppositely, liver $82 \mathrm{kDa}$ Nrf2 rose significantly $(\mathrm{P}<0.05)$ by 1.4 -fold during freezing, and then returned to near control levels during thawing. Freezing also caused $82 \mathrm{kDa} \mathrm{Nrf} 2$ to increase significantly $(\mathrm{P}<0.05)$ in brain, returning to control levels after thawing. In skin, freezing had no effect on the content of $82 \mathrm{kDa}$ Nrf2 but protein levels decreased significantly $(\mathrm{P}<0.05)$ by $40 \%$ after thawing. Neither 40 nor $82 \mathrm{kDa} \mathrm{Nrf} 2$ protein was detected in heart or kidney; the reason may be a very low content of Nrf2 in these two tissues. 


\subsubsection{Analysis of transcription factor MafG protein expression}

The small Maf proteins form heterodimers with Nrf2 to regulate the transcription of antioxidant genes. Since MafG may be the major small Maf that is involved in the Nrf2/ARE pathway (Blank et al., 1997), its content was examined in frog tissues. Levels of MafG protein in frog tissues are shown in Figure 3.11. Levels increased significantly $(\mathrm{P}<0.05)$ by 1.7 -fold during freezing in skeletal muscle, and further rose to 2.3 -fold higher than control values after thawing. A similar situation was seen in brain where MafG content increased 1.2-fold during freezing, and then rose significantly $(\mathrm{P}<0.05)$ by 1.7-fold after thawing. Freezing also affected the expression of MafG in liver, its content rising significantly $(\mathrm{P}<0.05)$ by 1.3 -fold but after $8 \mathrm{~h}$ thawing MafG was reduced again to control levels. By contrast, MafG content was stable in gut during freezing, but increased significantly $(\mathrm{P}<0.05)$ by 1.8 -fold after thawing. Freeze/thaw had no effect on MafG protein levels in skin.

\subsubsection{Analysis of nuclear translocation of $\mathrm{Nrf} 2$ and MafG in skeletal muscle}

In order to determine whether $\mathrm{Nrf} 2$ and MafG transferred to the nucleus from the cytoplasm during freeze/thaw, cytoplasmic and nuclear fractions were isolated from skeletal muscle tissue. The distributions of $\mathrm{Nrf2}(\sim 40 \mathrm{kDa}), \mathrm{Nrf} 2(\sim 82 \mathrm{kDa})$, and MafG in the two fractions were determined by western blotting. Figure 3.12 (A) shows a relative increase in the amount of $\mathrm{Nrf} 2(\sim 40 \mathrm{kDa})$ protein in both nuclear and cytoplasmic fractions during freezing but the relative amount of $\mathrm{Nrf} 2$ in the nuclear fraction changed very little compared with the control sample. However, the relative amount of $40 \mathrm{kDa}$ Nrf2 in the nucleus seemed to be reduced after thawing. Figure 3.12 (B) shows that the 
content of $\sim 82 \mathrm{kDa} \mathrm{Nrf} 2$ complex decreased overall in both cytoplasmic and nuclear fractions during freezing although the ratio nuclear:cytoplasmic increased somewhat during freezing, possibly because more $\mathrm{Nrf} 2(\sim 40 \mathrm{kDa})$ was dissociated from the putative complex. Figure 3.12 (C) shows a strong decrease in cytoplasmic MafG protein and a strong increase in nuclear content during freezing. This was reversed when the frogs thawed. This supports the idea that more MafG protein moved into the nuclei from the cytoplasm during freezing. 


\section{Figure 3.1}

Partial nucleotide and deduced amino acid sequence of the wood frog (Rana sylvatica) GST Pi gene product that was amplified from frog liver cDNA. Nucleotides and amino acids are numbered on the left. A single open reading

frame was predicted from the nucleotide to code for a polypeptide with 46 residues. 
1 TCCTCGGTTTCAGGATGGAGACATCACCATGTAGCGGCAGAATGCCATACTCCGCCATCTT

$\begin{array}{llllllllllllllllllllll}1 & \mathrm{P} & \mathrm{R} & \mathrm{F} & \mathrm{Q} & \mathrm{D} & \mathrm{G} & \mathrm{D} & \mathrm{I} & \mathrm{T} & \mathrm{M} & * & \mathrm{R} & \mathrm{Q} & \mathrm{N} & \mathrm{A} & \mathrm{I} & \mathrm{L} & \mathrm{R} & \mathrm{H} & \mathrm{L}\end{array}$

62 GCTAGGAATCATGGTCTGTATGGGAAAACTCCACTTGAGGCTGCACAGATAGACATGGTA

$\begin{array}{lllllllllllllllllllll}21 & A & R & N & H & G & L & Y & G & K & T & P & L & E & A & A & Q & I & D & M & V\end{array}$

122 AACGATGGCGTGGAAGATCTA

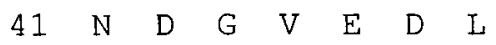




\section{Figure 3.2}

(A) Wood frog (Rana sylvatica) GST Pi partial nucleotide sequence aligned with African clawed frog (Xenopus laevis), house mouse (Mus musculus) and human (Homo sapiens) nucleotide sequences (Genbank accession numbers: AJ489617, NM_181796 and NM_000852, respectively).

For convenience only those nucleotides differing from the wood frog are indicated; distinct nucleotide substitutions in the wood frog sequence are indicated in bold underline. Dashes (-) represent nucleotides in the clawed frog, house mouse, and human sequences that are identical with the wood frog sequence.

(B) Homology tree of partial wood frog, clawed frog, house mouse and human GST Pi nucleotide sequences. 
(A)

Wood frog

Clawed frog House mouse Human

Wood frog Clawed frog House mouse Human

Wood frog Clawed frog House mouse Human

Wood frog Clawed frog House mouse Human

(B)

\section{$100 \% 95 \% 90 \% 85 \% 80 \% 75 \% 70 \% 65 \% 60 \%$}

TCCTCGGTTTCAGGATGGAGACATCACCATGTAGCGGCAG 40 g----a----------------tatgt-c-t--t-a-agt 40 c--caa----g----------c-----c-t--c-aatct 40 c--caa---c-----c------c-----c----c-a-tcc 40

AATGCCATACTCCGCCATCTTGCTAGGAATCATGGTCTGT 80 --cagt--t--aa-gt----g-g--at--a-----a---a 80 -------ct-ga-a--c----gcc-ctc-ttg--g--t- 80 $---a----c--g--t--c--g-g c c-c-c c-t---g--c-80$

ATGGGAAAACTCCACTTGAGGCTGCACAGATAGACATGGT 120 C---agcc-ā-gātgag--acg--gt--c---------- 120 --------ac-agagg-----c--c-----g--t----- 120 -------ggac-ag-ag-----a--c-t-g-g-------- 120

AAACGATGGCGTGGAAGATCTA 142 $\bar{g}-\cdots------------g 142$

g--t-----g-----g--c--t 142

g--t--c--------g--c--c 142

Wood frog

House mouse

Hum an

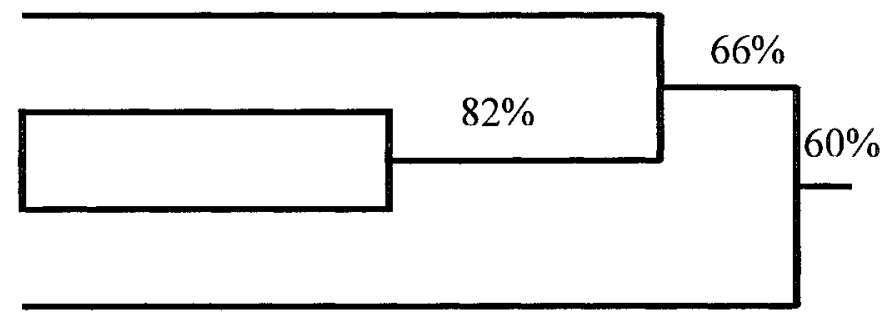

A frican clawed frog 


\section{Figure 3.3}

(A) Wood frog (Rana sylvatica) GST Pi partial amino acid sequence aligned with clawed frog (Xenopus laevis), house mouse (Mus musculus) and human (Homo sapiens) GST Pi amino acid sequences. Genbank accession numbers: CAD33920, NP_861461, NP_000843, respectively).

For convenience only those amino acids differing from the wood frog are indicated; distinct amino acid substitutions in the wood frog sequence are indicated in bold underline. Dashes (-) represent amino acids in the clawed frog, house mouse, and human sequences that are identical with the wood frog sequence.

(B) Homology tree of partial wood frog, clawed frog, house mouse and human GST Pi amino acid sequences. 
(A)

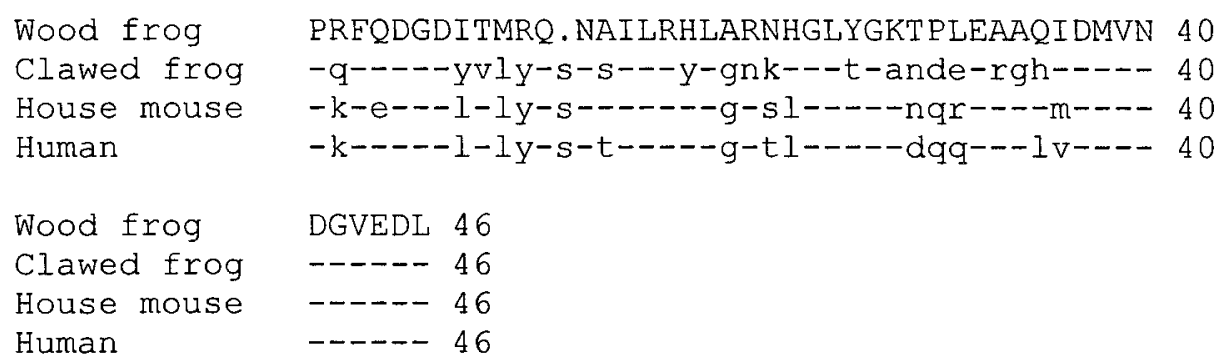

(B)
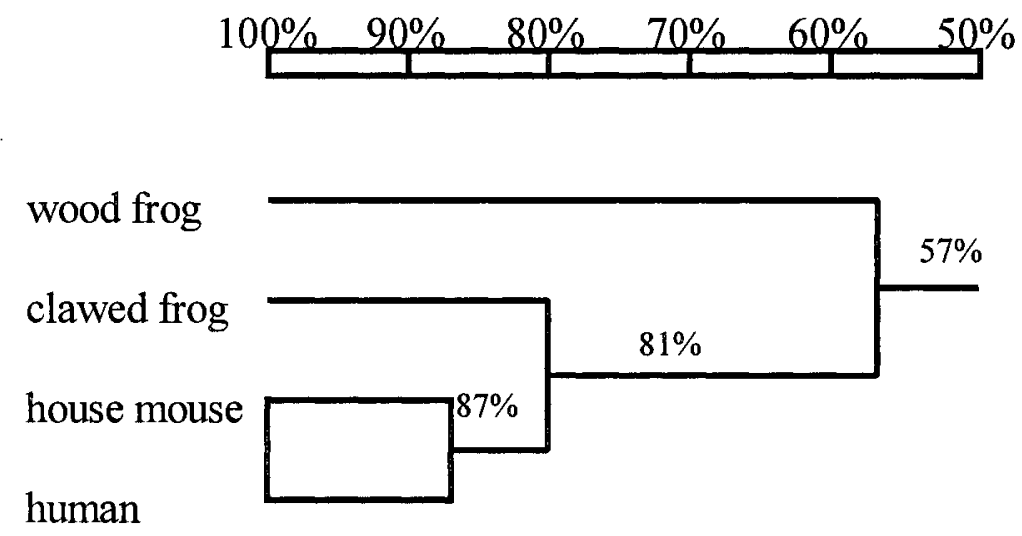


\section{Figure 3.4}

Western blots analysis of GST Pi protein content in brain, gut, liver, kidney, heart and skeletal muscle of wood frogs from three conditions: control $\left(5^{\circ} \mathrm{C}\right.$ acclimated), frozen $\left(24 \mathrm{~h}\right.$ at $\left.-2.5^{\circ} \mathrm{C}\right)$ and thawed recovery $\left(8 \mathrm{~h}\right.$ at $5^{\circ} \mathrm{C}$ after $24 \mathrm{~h}$ frozen).

(A) Representative full blots for kidney samples showing only one GST Pi cross-reacting band at $\sim 30 \mathrm{kDa}$. Three independent samples are shown for each condition: Control, lanes 1-3; Frozen lanes, 5-7; Thawed, lanes 9-11. A commercial protein ladder (L) from Bio-Rad Laboratories is shown in lane 8. Lane 12 shows a GST Pi band from Ground Squirrel liver sample as a comparison.

(B) Representative Western blots showing GST Pi protein levels in tissues from control (C), frozen (F) and recovered (R) frogs.

(C) Relative levels of GST Pi protein in frozen and thawed frogs as compared with controls. Histogram shows mean $\pm S E M, n=3$ independent determinations. * - Significantly different from the corresponding control value for the same tissue using the Student's t-test, $\mathrm{P}<0.05$. 
(A)

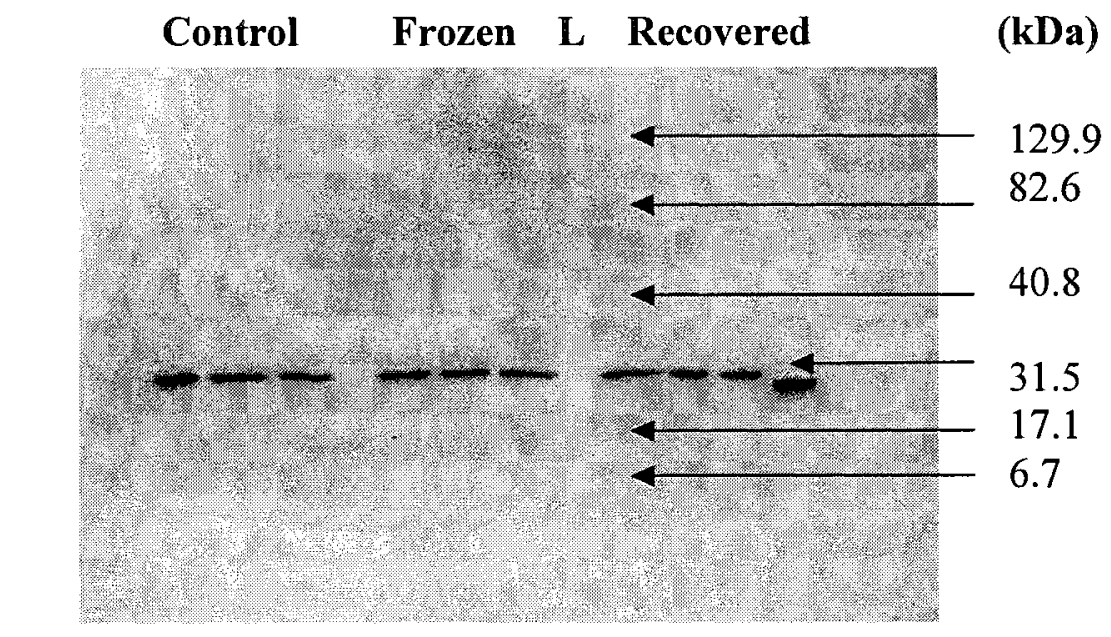

\section{$\begin{array}{lllllllllllll}\text { Lanes } & 1 & 2 & 3 & 4 & 5 & 6 & 7 & 8 & 9 & 10 & 11 & 12\end{array}$}

(B)

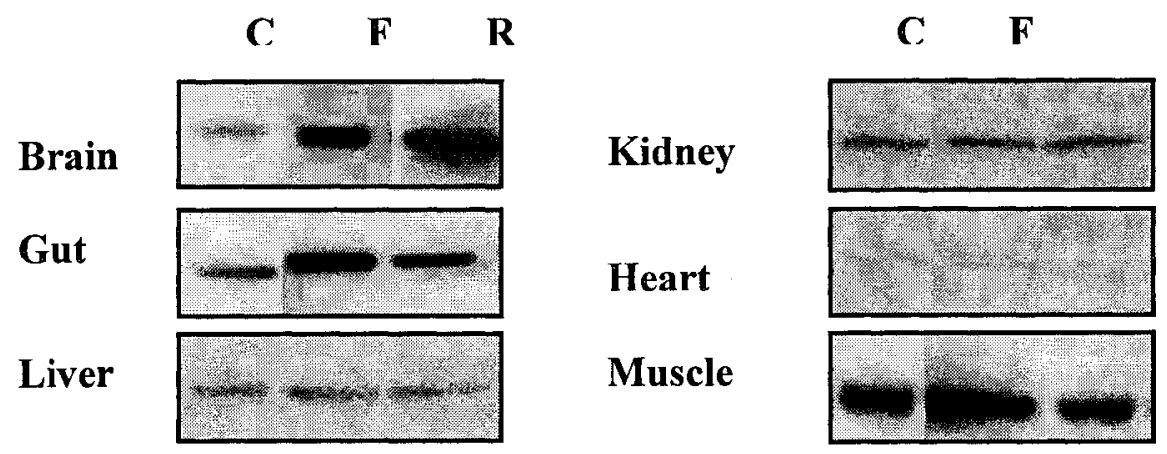

(C)

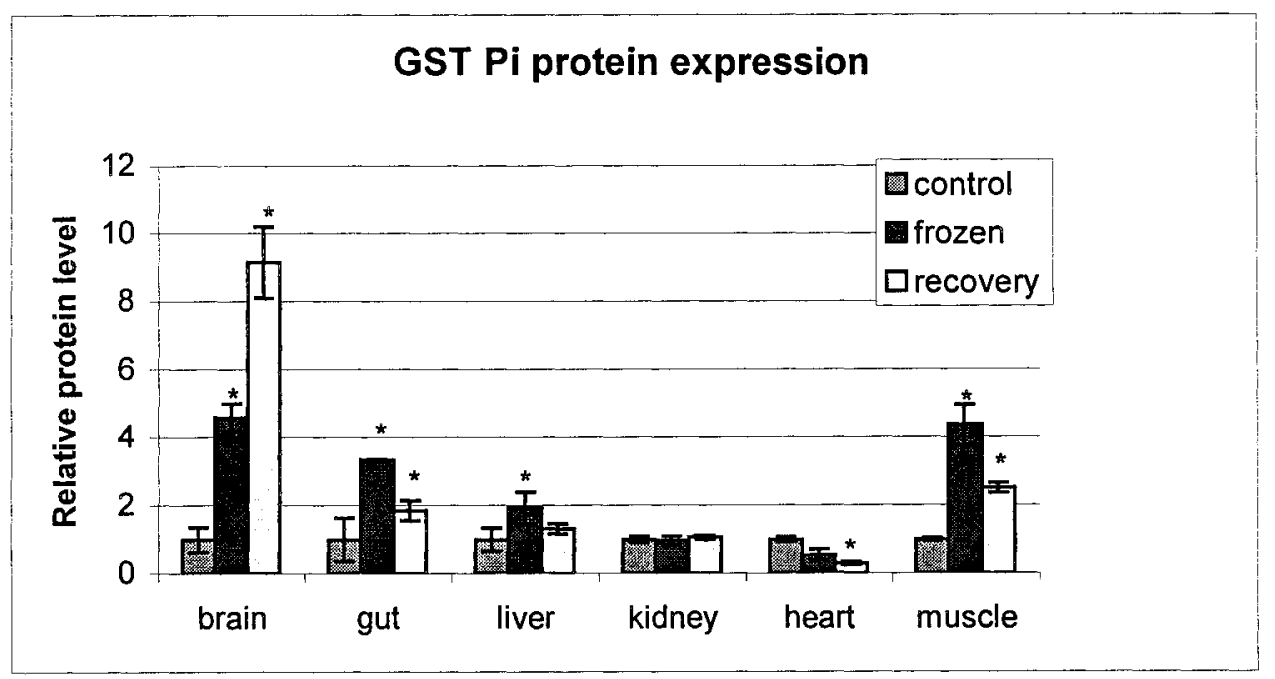




\section{Figure 3.5}

Analysis of GST Pi mRNA transcript levels in wood frog tissues by RT-PCR.

(A) Examples of expression of alpha-tubulin and GST Pi in a serial dilution of liver cDNA from control, frozen and thawed recovery samples.

(B) Relative GST Pi transcript levels in brain, gut, liver, kidney, heart and muscle of wood frogs from three conditions: control $\left(5^{\circ} \mathrm{C}\right.$ acclimated), frozen $\left(24 \mathrm{~h}\right.$ at $\left.-2.5^{\circ} \mathrm{C}\right)$ and thawed recovery $\left(8 \mathrm{~h}\right.$ at $5^{\circ} \mathrm{C}$ after $24 \mathrm{~h}$ frozen) determined by RT-PCR. The $10^{-4}$ dilution was quantified for the histogram. Histogram shows mean $\pm \mathrm{SEM}, \mathrm{n}=4$ independent determinations. * - Significantly different from the corresponding control value for the same tissue using the Student's t-test, $\mathrm{P}<0.05$. 
(A)

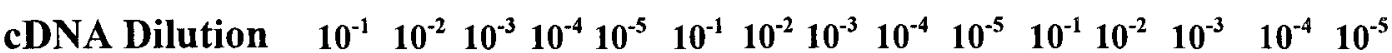

$\alpha$-Tubulin

GST-Pi
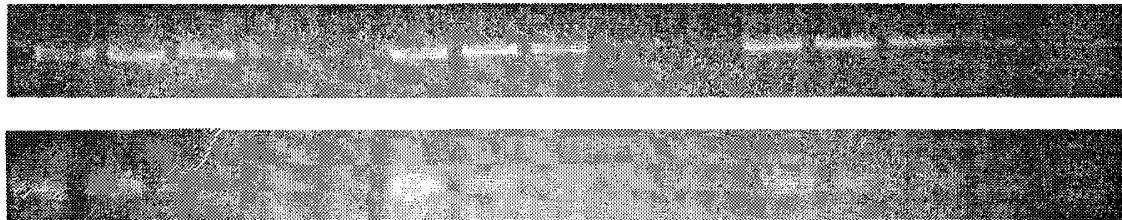

Control

Frozen

Recovery

(B)

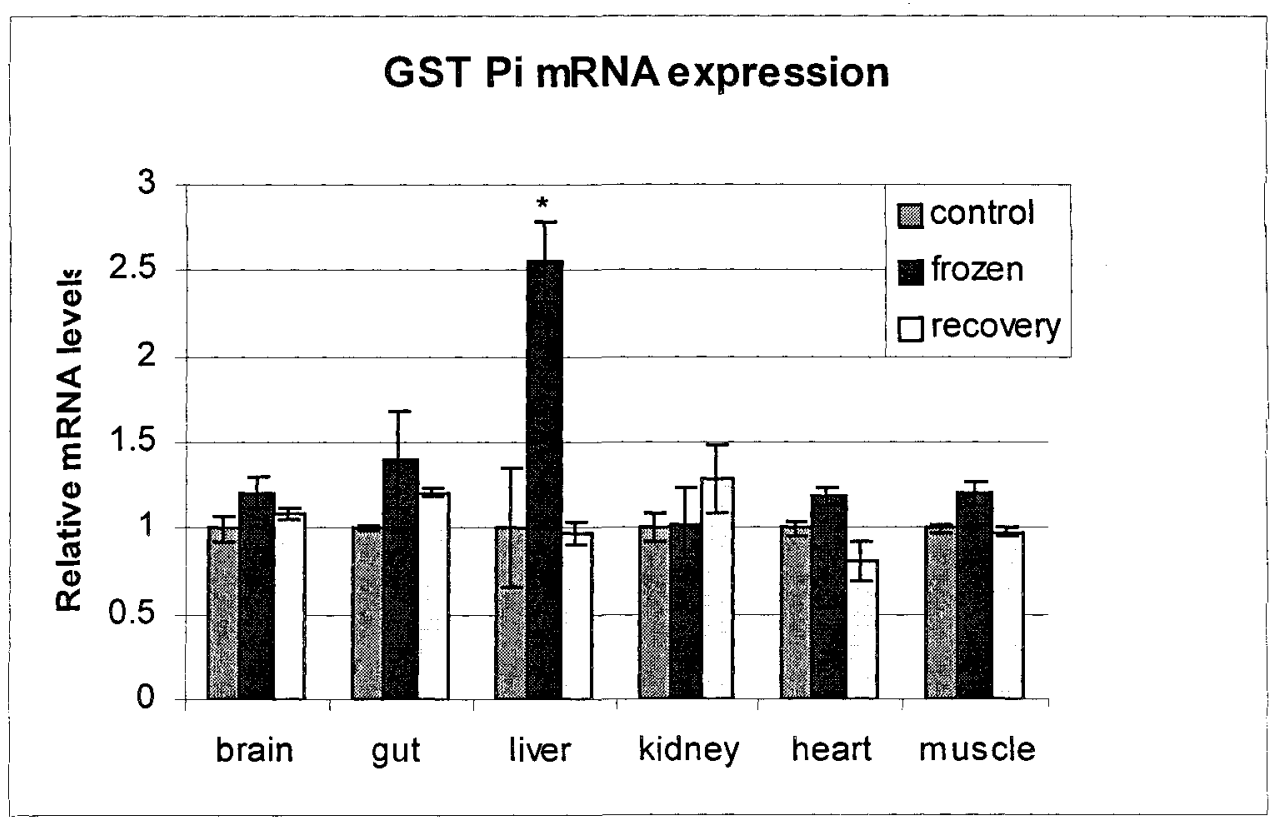




\section{Figure 3.6}

Western blot analysis of GST M1/2 protein content in brain, gut, liver, muscle, kidney and skin of wood frogs from three conditions: control $\left(5^{\circ} \mathrm{C}\right.$ acclimated), frozen $\left(24 \mathrm{~h}\right.$ at $\left.-2.5^{\circ} \mathrm{C}\right)$ and thawed recovery $\left(8 \mathrm{~h}\right.$ at $5^{\circ} \mathrm{C}$ after $24 \mathrm{~h}$ frozen).

(A) Representative Western blots showing GST M1/2 protein levels in tissues from control (C), frozen (F) and recovered (R) frogs.

(B) Relative levels of GST M1/2 protein in frozen and thawed frogs as compared with controls. Histogram shows mean \pm SEM, $n=4$ independent determinations. ${ }^{*}$ - Significantly different from the corresponding control value for the same tissue using the Student's t-test, $\mathrm{P}<0.05$. 
(A)

\begin{tabular}{|c|c|c|c|}
\hline & $\begin{array}{lll}\mathbf{C} & \mathbf{F} & \mathbf{R}\end{array}$ & & $\begin{array}{lll}\mathbf{C} & \mathbf{F} & \mathbf{R}\end{array}$ \\
\hline Brain & $75+5-5$ & Muscle & 20 \\
\hline Gut & - & Kidney & 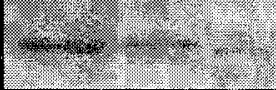 \\
\hline Liver & 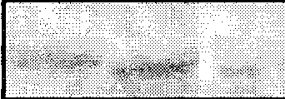 & Skin & 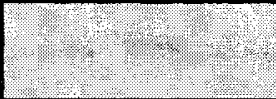 \\
\hline
\end{tabular}

(B)

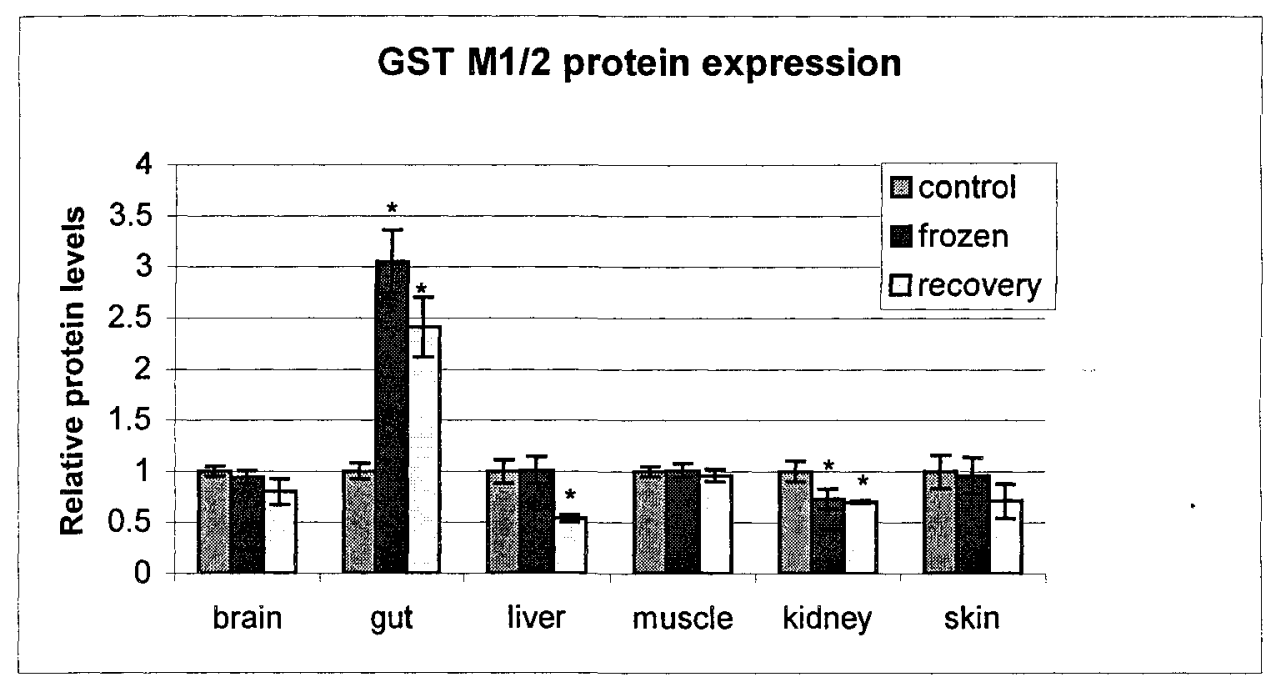




\section{Figure 3.7}

Western blot analysis of GSTA5 protein content in liver and muscle of wood frogs from three conditions: control $\left(5^{\circ} \mathrm{C}\right.$ acclimated), frozen $\left(24 \mathrm{~h}\right.$ at $\left.-2.5^{\circ} \mathrm{C}\right)$ and thawed recovery $\left(8 \mathrm{~h}\right.$ at $5^{\circ} \mathrm{C}$ after $24 \mathrm{~h}$ frozen).

(A) Western blots showing GST A5 protein levels in tissues from control $(C)$, frozen $(F)$ and recovered $(R)$ frogs; $n=3$ independent samples are shown for each condition.

(B) Relative levels of GST A5 protein in frozen and thawed frogs as compared with controls. Histogram shows mean \pm SEM, $n=3$ independent determinations. ${ }^{*}$ - Significantly different from the corresponding control value for the same tissue using the Student's t-test, $\mathrm{P}<0.05$. 
(A)

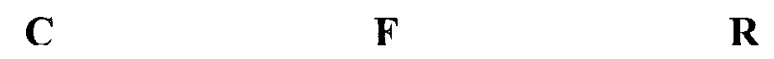

Liver

Muscle
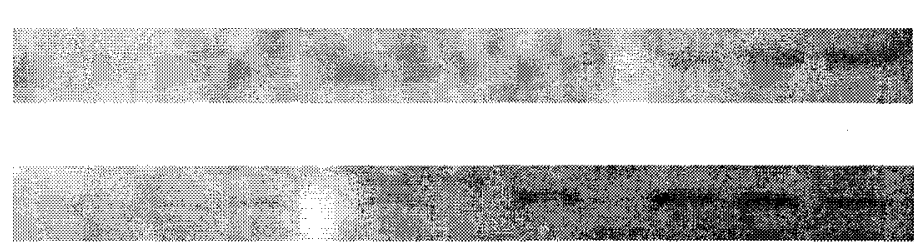

$$
n=1 \quad n=2 \quad n=3 \quad n=1 \quad n=2 \quad n=3 \quad n=1 \quad n=2 \quad n=3
$$

(B)

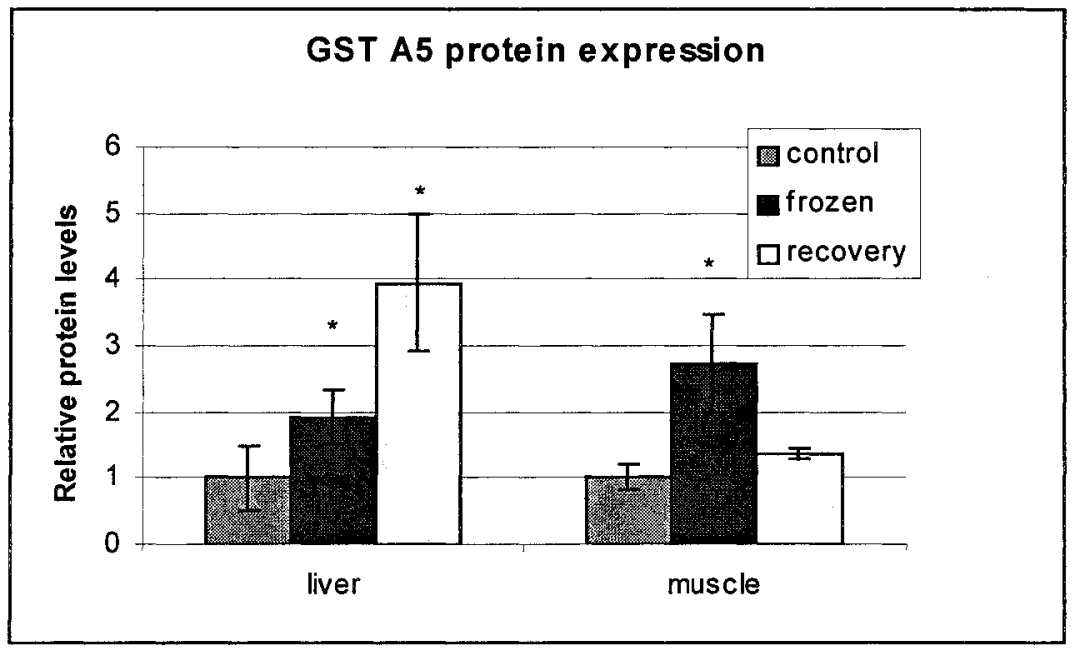




\section{Figure 3.8}

Western blot showing GST M5 and GST A3 protein contents in control, frozen and thawed wood frogs.

(A) Western blots showing GST M5 protein levels in muscle from control, frozen and thawed recovery of wood frogs; $n=3$ independent samples are shown for each condition.

(B) Relative levels of GST M5 protein in muscle of wood frogs. Histogram shows mean \pm SEM, $n=3$ independent determinations. * Significantly different from the corresponding control value, $\mathrm{P}<$ 0.05

(C) Western blots showing GST A3 protein levels in liver from control, frozen and thawed recovery frogs; $n=3$ independent samples are shown for each condition.

(D) Relative levels of GST A3 protein in liver of control, frozen and recovered wood frogs as determined from western blotting. Histogram shows mean $\pm \mathrm{SEM}, \mathrm{n}=3$ independent determinations. * Significantly different from the corresponding control value, $\mathrm{P}<$ 0.05 . 
(A)

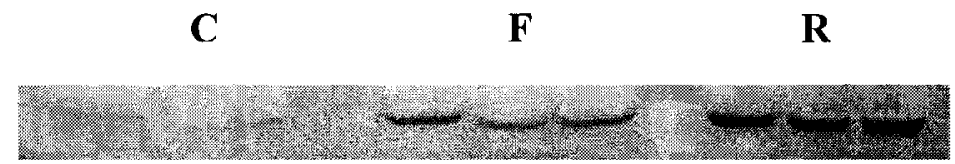

$$
n=1 \quad n=2 \quad n=3 \quad n=1 \quad n=2 \quad n=3 \quad n=1 \quad n=2 \quad n=3
$$

(B)

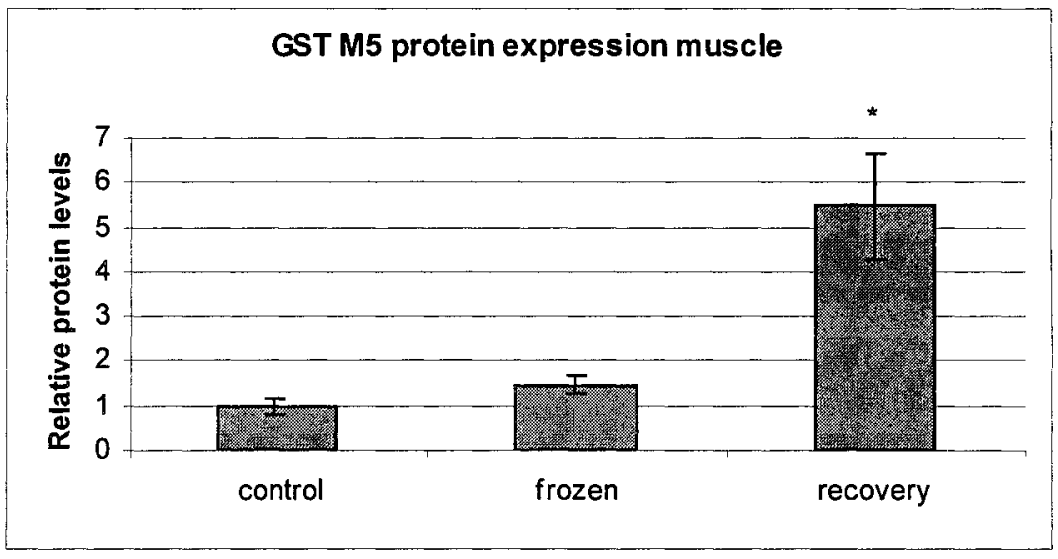

(C)
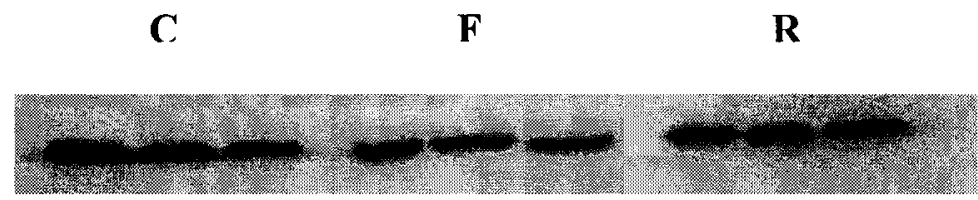

$n=1 \quad n=2 \quad n=3 \quad n=1 \quad n=2 \quad n=3 \quad n=1 \quad n=2 \quad n=3$

(D)

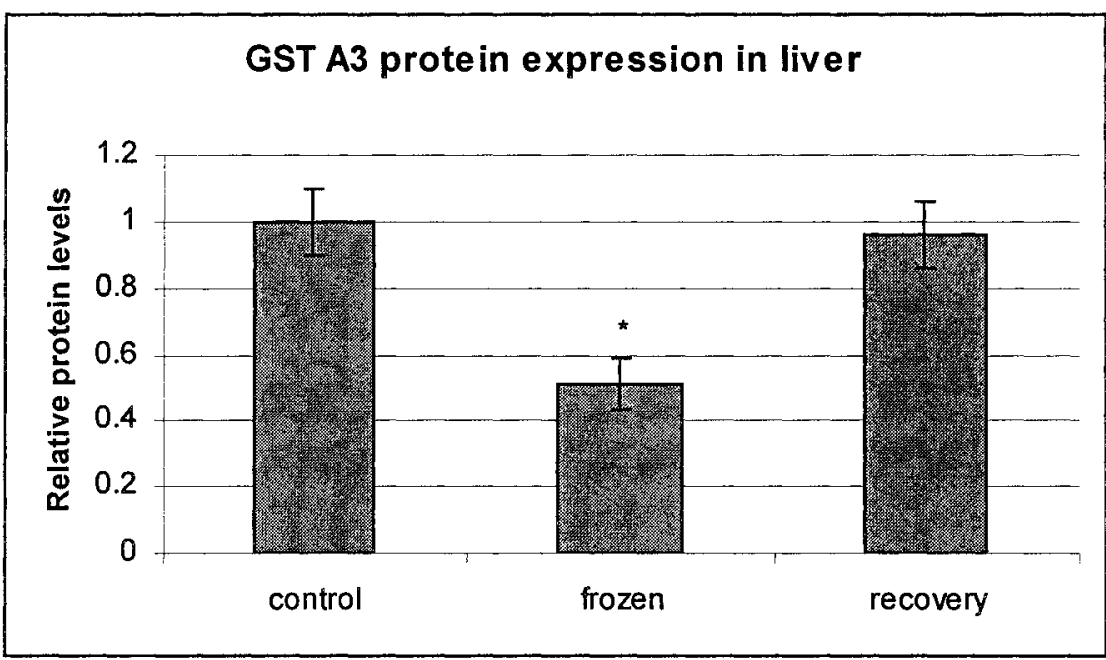




\section{Figure 3.9}

Western blots showing Nrf2 ( 40 kDa) protein contents in brain, gut, skin, muscle and liver from control, frozen and thawed frogs.

(A) Representative of full blot for brain samples showing two distinct cross-reacting bands at $\sim 40 \mathrm{kDa}$ and $\sim 82 \mathrm{kDa}$. Four independent samples are shown for each condition: Control (lanes 1-4), Frozen (lanes 5-8), Thawed (lanes 9-12). A protein ladder (L; lane 13) from Bio-Rad Laboratories is shown in the far right lane

(B) Representative western blots showing $\mathrm{Nrf} 2(\sim 40 \mathrm{kDa})$ levels in tissues from control (C), frozen (F) and thawed recovery (R) samples.

(C) Relative levels of $\mathrm{Nrf} 2(\sim 40 \mathrm{kDa})$ protein in tissues of brain, gut, skin, liver and muscle from control, frozen and recovery samples as determined from western blotting. Histogram shows mean $\pm \mathrm{SEM}$, $\mathrm{n}=4$ independent determinations. * - Values for frozen or recovery samples are significantly different than the corresponding control values, $\mathrm{P}<0.05$. 
(A)

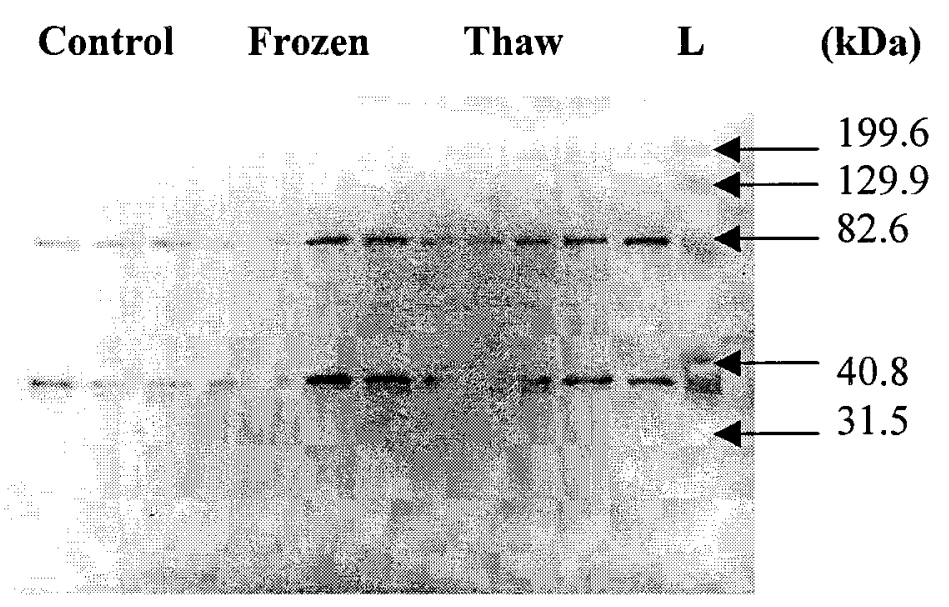

$\begin{array}{lllllllllllll}1 & 2 & 3 & 4 & 5 & 6 & 7 & 8 & 9 & 10 & 11 & 12 & 13\end{array}$

(B)

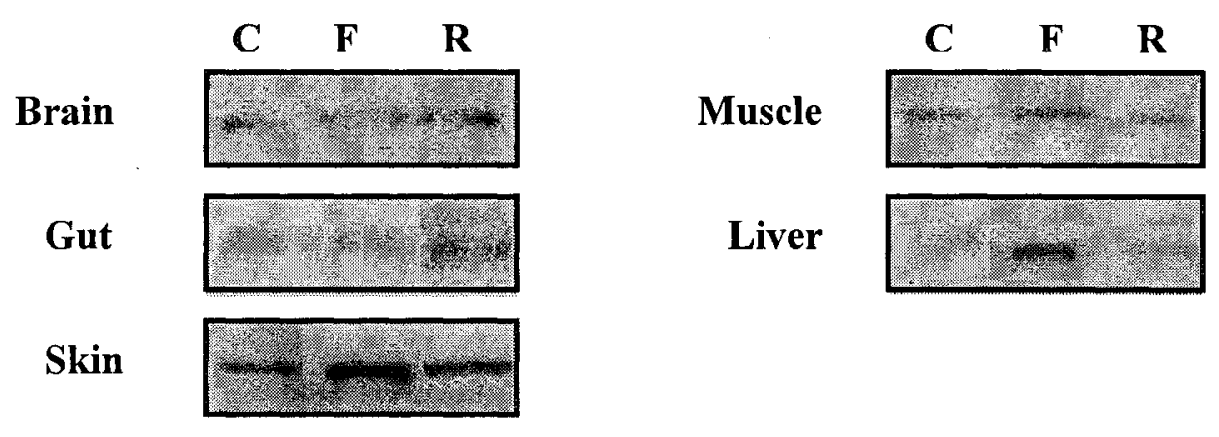

(C)

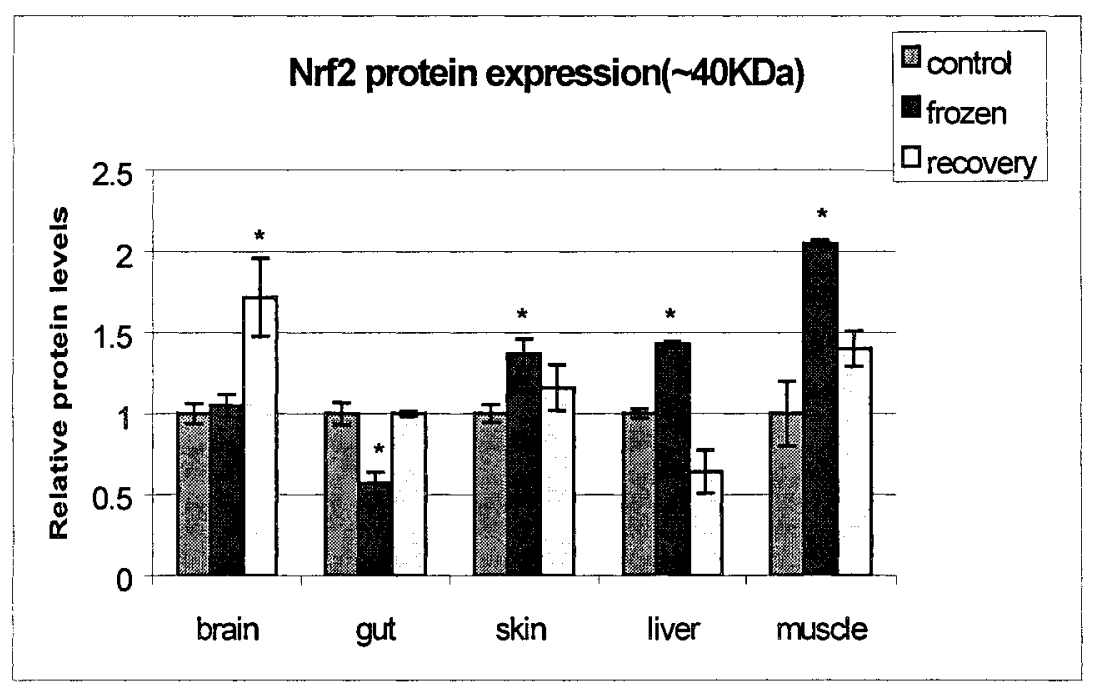




\section{Figure 3.10}

Western blots showing Nrf2 ( $\sim 82 \mathrm{kDa})$ protein contents in brain, gut, skin, muscle and liver from control, frozen and thawed frogs.

(A) Representative of western blots showing Nrf2 ( $\sim 82 \mathrm{kDa})$ levels in tissues from control (C), frozen $(\mathrm{F})$ and thawed recovery $(\mathrm{R})$ samples.

(B) Relative levels of $\mathrm{Nrf} 2(\sim 82 \mathrm{kDa})$ protein brain, gut, skin, liver and muscle from control, frozen and recovered frogs as determined from western blotting. Histogram shows mean \pm SEM, $n=4$ independent determinations. * - Values for frozen or recovery samples are significantly different than the corresponding control value, $\mathrm{P}<0.05$. 
(A)

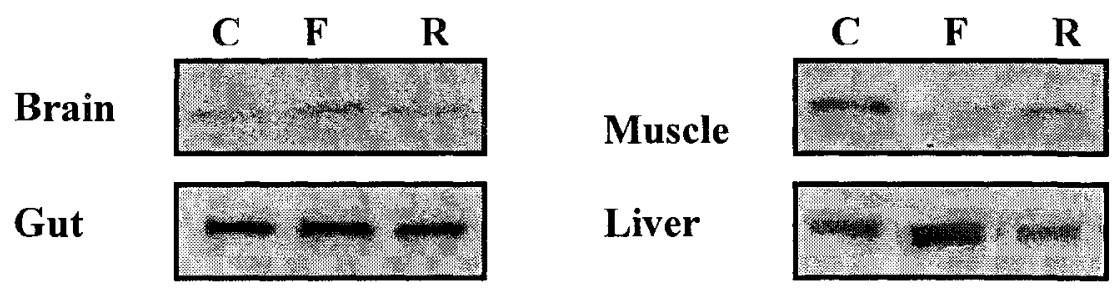

Skin

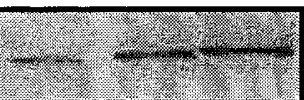

(B)

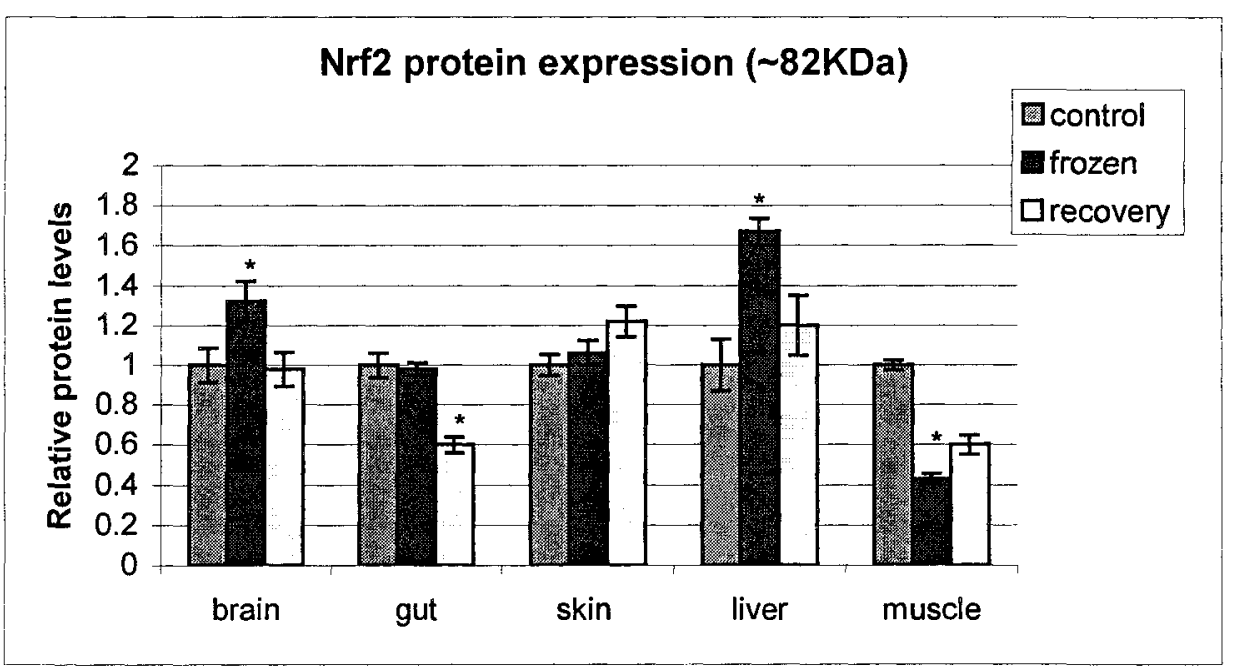




\section{Figure 3.11}

Western blots showing MafG protein contents in tissues of control, frozen and thawed wood frogs.

(A) Representative western blots showing MafG protein levels in brain, muscle, gut, liver, and skin from control, frozen and thawed recovery frogs.

(B) Relative levels of MafG protein in wood frog tissues. Histogram shows mean \pm SEM, $\mathrm{n}=4$ independent determinations. * Significantly different from the corresponding control values, $\mathrm{P}<$ 0.05 . 
(A)

$\begin{array}{lll}\mathbf{C} & \mathbf{F} & \mathbf{R}\end{array}$

\section{Brain}

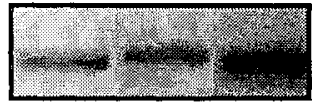

Muscle

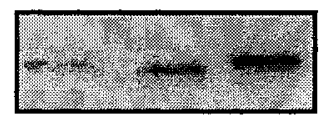

Gut

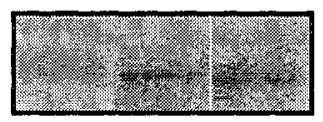

\section{C $\quad \mathrm{F} \quad \mathrm{R}$}

Liver

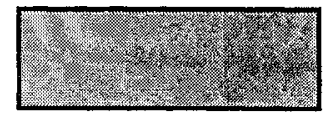

Skin

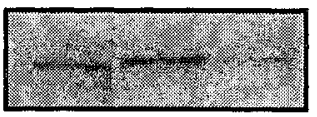

(B)

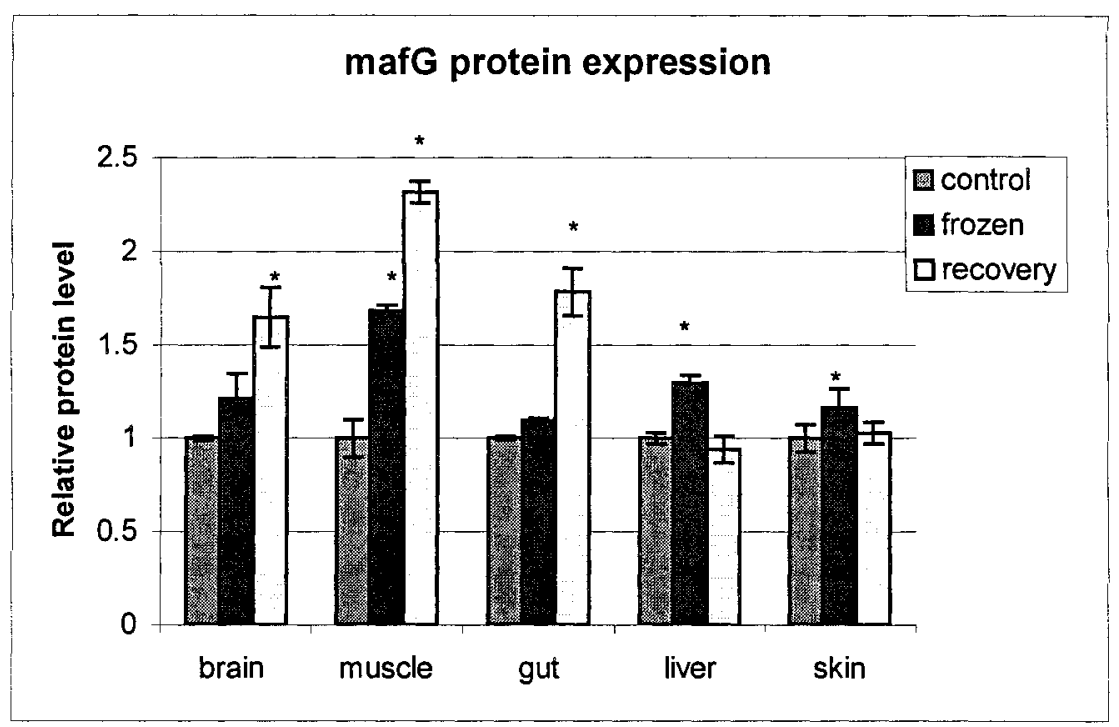




\section{Figure 3.12}

Analysis of Nrf2 and MafG protein distribution between cytoplasmic and nuclear fractions of muscle in control, $24 \mathrm{~h}$ frozen and $8 \mathrm{~h}$ thawed recovery wood frogs. Data are expressed relative to protein levels in control cytoplasm.

(A) Relative $\mathrm{Nrf2}(\sim 40 \mathrm{kDa})$ protein distribution between cytoplasmic and nuclear fractions of muscle tissue determined by western blotting. Data are $n=1$ trial.

(B) Relative Nrf2 ( $\sim 82 \mathrm{kDa})$ protein distribution between cytoplasmic and nuclear fractions of muscle tissue determined by western blotting. Data are $n=1$ trial.

(C) Relative MafG protein distribution between cytoplasmic and nuclear fractions of muscle tissue determined by western blotting. Data are $n=$ 1 trial. 
(A)

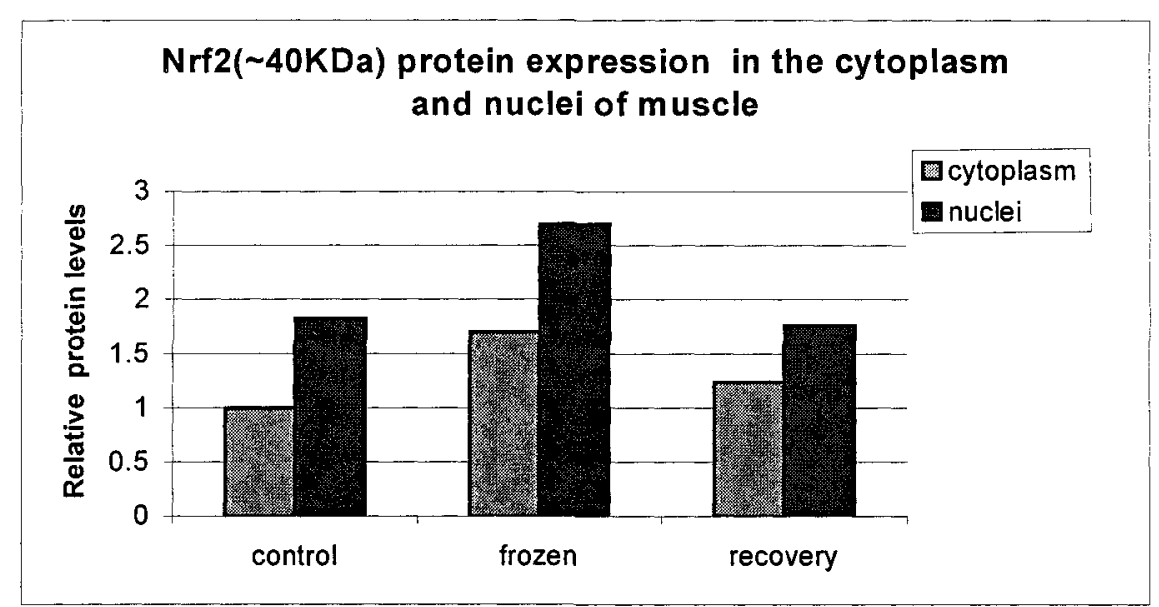

(B)

(C)
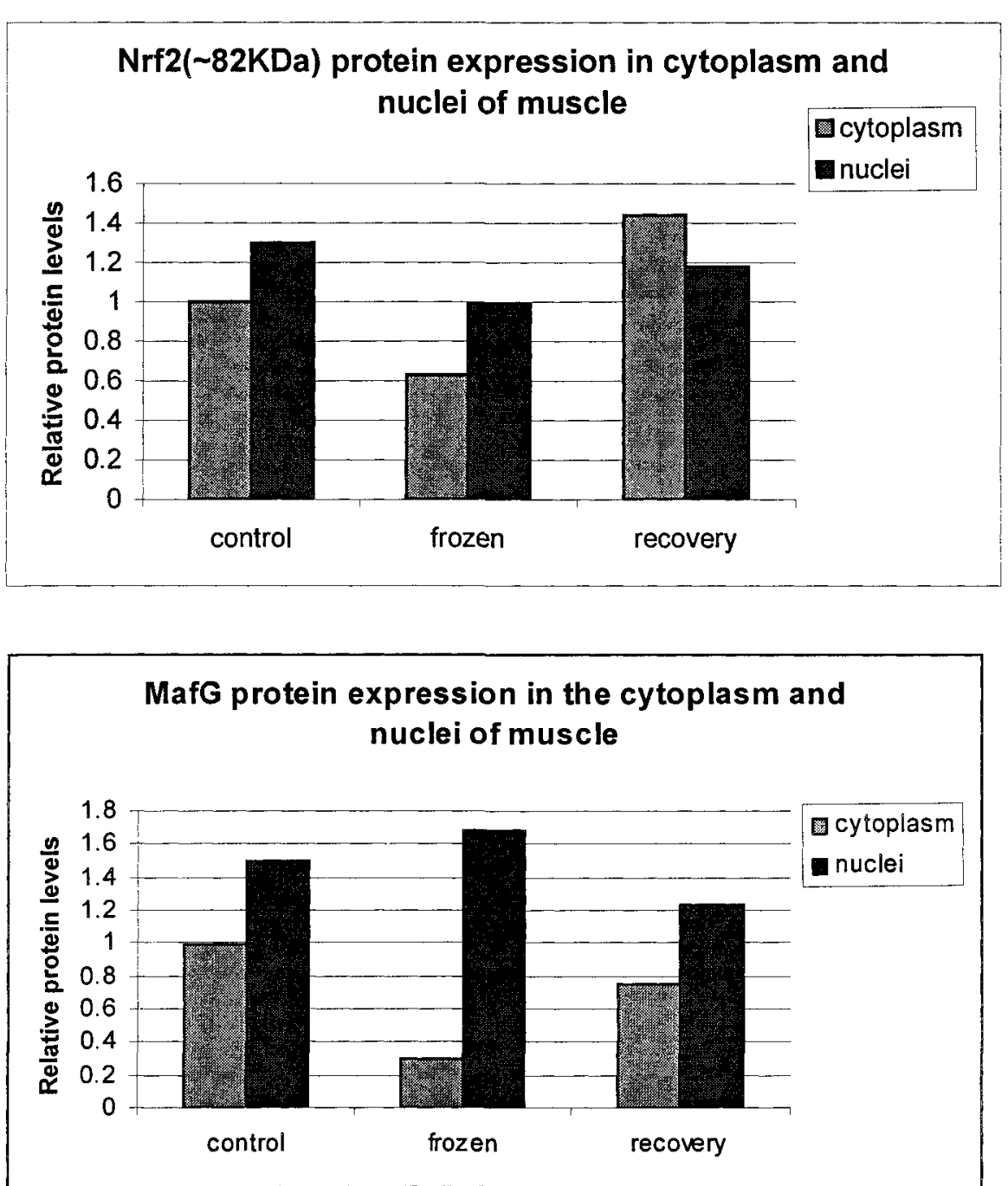


\subsection{Discussion}

\subsubsection{Structural analysis of GST Pi sequences in wood frogs, $R$. sylvatica}

The data from analysis of wood frog GST Pi nucleotide and putative amino acid sequences demonstrate that GST Pi shares high identity with the isoform from other species, both mammalian and amphibian. Indeed, the protein is known to be highly conserved across phylogeny. In particular, about $66 \%$ nucleotide identity and $57 \%$ amino acid identity were seen with mammalian and African clawed frog Xenopus laevis, respectively.

Previous studies of the structure of GSTs in mammals have shown that cytosolic GSH transferases are invariably either homodimeric or heterodimeric species (Armstrong 1997). All of the structures of GSTs have the same basic protein fold that consists of two domains; the overall fold of the $\mathrm{N}$-terminal domain is classified as part of the thioredoxin superfamily fold, which also includes glutaredoxin, disulfide-bond formation facilitator and glutathione peroxidase (Murzin et al., 1995). This domain constitutes roughly onethird of the protein and consists of a $\beta-\alpha-\beta-\alpha-\beta-\beta-\alpha$ structural motif that forms a mixed four-strand $\beta$-sheet. The core of the domain is composed of three layers with the $\beta$-sheet sandwiched between $\alpha$-helices. The C-terminal two-thirds of the protein is an all- $\alpha$ helical domain with a unique protein fold, the core of which consists of a bundle of four helices (Armstrong, 1997). The high degree of GST Pi sequence conservation between the wood frog sequence and GST Pi from other species indicates that the wood frog protein probably contains the same functional domain(s) as the protein from other species and undoubtedly carries out the same roles in vivo in protecting macromolecules from oxidative and toxic stresses. 


\subsubsection{Analysis of transcription and translation induction of GST Pi}

Previous studies with wood frogs in our lab have shown that two strategies contribute to the defense against oxidative stress associated with freeze-thaw. One is to maintain high constitutive activities of antioxidant enzymes in frog organs. For example, the activity of GST was substantially higher in wood frog than in leopard frog organs (Joanisse and Storey, 1996; Storey and Storey, 2004). The other principle is selective changes to the activities of some enzymes in response to freezing. For instance, seleniumdependent glutathione peroxidase activity rose by about two-fold in heart, kidney, and skeletal muscle (Joanisse and Storey, 1996). In most cases, activities returned to near control levels after $24 \mathrm{~h}$ thawing. This indicates that the need for enhanced defenses against peroxidative damage is greatest during freezing and immediately after thawing (Storey and Storey, 2004). For further understanding of the mechanisms of antioxidant defense in wood frogs, it is necessary to check the relevant freeze-induced changes in protein expression and transcript levels.

To characterize the GST Pi response to freeze/thaw stress in wood frogs, GST Pi transcript levels and protein expression were assessed by RT-PCR and western blotting, respectively. The results (Fig. 3.4) show that inducible GST Pi is differently regulated in some tissues of wood frogs. In brain, gut, liver and skeletal muscle, GST Pi protein content rose during $24 \mathrm{~h}$ freezing and remained elevated after $8 \mathrm{~h}$ thawing, except in liver. So, based on higher protein levels, it is probable that the activity of GST is also elevated during freezing and early thawing in these organs. This supports the previous conclusion that GST Pi plays an important role in antioxidant defense against oxidative 
stress associated with freeze-thaw, an ischemia-reperfusion event. As for kidney and heart, no change or reduced levels of GST Pi protein suggests that this isoform of GST is of lesser importance to antioxidant defense during freezing in these organs.

GST Pi transcript levels were strongly up-regulated in liver during freezing (Fig. 3.5), and this is consistent with the enhanced protein expression seen in this organ. This suggests that freezing triggers increased expression of the GST Pi gene in liver. This also supports the idea that GST Pi mRNA substrate availability is a primary determinant of the level of GST protein in liver. However, GST Pi transcript levels in brain, gut, and skeletal muscle did not increase during freezing and, hence, did not correlate with the elevated GST Pi protein levels in these tissues. A primary point of general gene regulation is transcription (Darnell et al., 1982), specifically at initiation (Bentley et al., 1996). However, gene expression may also be regulated by other mechanisms. For example, various proteins are regulated by mRNA stability; the more stable the mRNA, the greater the number of proteins produced from any one transcript. This level of regulation has been shown to occur primarily in transient states (e.g., shock) when protein production must be rapid and usually occurs concurrent with increased transcription rates (White et al., 1999). Regulation can also occur by altering the rate of translation of selected transcripts (e.g. transcripts can be stored in association with binding proteins until a signal frees them for translation) or by altering the stability of the protein once synthesized. The dichotomy between freeze-activated elevation of GST Pi protein levels in wood frog organs and the lack of mRNA increase suggests that controls on the translation of GST Pi transcripts may also be part of the regulation of this enzyme during freezing. 


\subsubsection{Analysis of results of GST M1/2, GST M5, GST A3, and GST A5 proteins}

Glutathione S-transferases are a complex group of proteins. They possess various activities and participate in several different types of reactions. In addition to conjugation reactions, many GST isoenzymes exhibit other GSH-dependent catalytic activities including the reduction of organic hydroperoxides and isomerisation of various unsaturated compounds. They may be involved in the sequestering of carcinogens and the intracellular transport of a wide spectrum of hydrophobic ligands (Sherratt et al., 2002). In addition to the GST Pi isozyme, members of other GST subfamilies were assessed in wood frog organs via western blotting including GST M1/2, GST M5, GST A5, and GST A3. GST M1/2 and GST M5 belong to the GST Mu subfamily whereas GST A3 and GST A5 are members of the GST alpha subfamily. The data for GST M1/2 show that this isozyme was not up-regulated during freezing in wood frog tissues except for gut (Fig.3.6) This suggests that GST M1/2 isoform is not involved in freeze/thaw antioxidant defense in these organs. GST M5 was only detected in skeletal muscle and there it was strongly up-regulated during thawing. This suggests that GST M5 plays a vital function in antioxidant defense during the recovery processes in muscle; however, the catalytic preferences of this isoform are still not clear (Hayes et al., 1995). Similar to GST M5, the GST A3 isozyme was only detected in one organ of wood frogs (liver) where its protein levels were significantly reduced freezing. This suggests that this isoform does not have a role in the antioxidant defense response to freeze/thaw and probably has other roles in vivo. GST A5 was up-regulated in both liver and skeletal muscle during freezing and rose further during thawing in liver. This is evidence that this GST isoenzyme might protect 
liver and skeletal muscle from oxidative damage during freeze/thaw. In mammals, Kazi et al. (2002) reported that GST A5 protein level significantly increased the resistance towards alkylating agents and toxic aldehydes in rat liver.

\subsubsection{ARE/Nrf2 pathway and gene regulation of GSTs}

Most studies in mammals have shown that a group of oxidative stress inducible genes is under the immediate transcriptional control of Nrf2 (Figure 3.1). Upon stimulation from ROS or other toxic materials, Nrf2 forms a heterodimer with a small Maf protein, interacts with the antioxidant responsive element (ARE) in the promoter region of genes, and induces the transcriptions of a set of genes that encode antioxidants, including GST, NQO1, HO-1, catalase, and thioredoxin. Thus, Nrf2 regulates stress inducible antioxidant genes via the ARE. Chanas et al. (2002) reported that the loss of Nrf2 caused a marked reduction in both the constitutive and inducible expression of GST alpha genes in the liver of male and female mice.

The present results indicate that the up-regulation of GSTs observed in some wood frogs organs during freeze/thaw is probably mediated by the Nrf2·MafG/ARE pathway. Western blotting analysis of Nrf2 and MafG demonstrated that levels of both proteins were up-regulated in brain, liver, and skeletal muscle during the freeze/thaw process. This is consistent with the results for GST Pi protein expression in these three organs, and in liver, also correlates well with the elevated levels of GST Pi mRNA transcripts in the frozen frog. Taken together, these results strongly suggest that Nrf2 and MafG transcriptionally activated GST gene expression in brain, liver, and skeletal muscle, leading to increased levels of GST protein synthesis during the freeze/thaw 
process. For other tissues, no good correlations between Nrf2, MafG and GST protein levels were seen in gut and skin. Although GST Pi protein was elevated in gut (and mRNA levels showed an increasing trend) and MafG levels were also increased significantly, Nrf2 protein content was reduced in gut during freeze/thaw. Hence, another mechanism of transcriptional regulation may be involved in the freeze/thaw responsive expression of GST Pi in gut tissue. In skin, Nrf2 levels were increased during freezing, and MafG protein levels were stable, but no GST Pi isoenzyme was detected. Probably other antioxidant enzymes or other GST isoforms were induced in this tissue.

Western blot analysis detected Nrf2 in two distinct bands, at approximately 40 $\mathrm{kDa}$ and $82 \mathrm{kDa}$, respectively, in all five frogs organs tested. It has been reported that the molecular weight of $\mathrm{Nrf} 2$ is $57 \mathrm{kDa}$ in mammals; however, it was around $40 \mathrm{kDa}$ in wood frog organs. The denaturing conditions of SDS-PAGE typically disrupt noncovalent protein-protein interactions so the detection of $\mathrm{Nrf} 2$ in an $82 \mathrm{kDa}$ band indicates a covalent complex between Nrf2 and another protein. Kang et al. (2002) demonstrated that treatment of the Nrf2 complex from a rat hepatoma cell line with a phosphatase released a $57 \mathrm{kDa} \mathrm{Nrf} 2$. The authors also showed that Nrf2 bound with actin in a covalent linkage to form a $100 \mathrm{kDa}$ complex. The $82 \mathrm{kDa} \mathrm{Nrf} 2$ complex in wood frog tissues may have a similar composition although further work is needed to determine what molecule combines with $\mathrm{Nrf2}$, what the role of the Nrf2 complex is, and how the two proteins combine together.

Oxidative stress causes the Keap1 protein to disassociate from Nrf2 and then Nrf2 translocates into the nucleus to induce transcription of antioxidant genes (Itoh et al., 1999). Thus, activation of Nrf2 should change the distribution of the protein between 
cytoplasmic and nuclear fractions. However, the data from subcellular fractionation of skeletal muscle followed by western blotting analysis of $\mathrm{Nrf2}$ does not support this opinion for frog skeletal muscle because the apparent changes in Nrf2 levels in the nuclear and cytoplasmic fractions during freezing were very small compared with controls. The decrease in the amount of $\mathrm{Nrf} 2$ in the $82 \mathrm{kDa}$ complex during freezing may be the source of the increased levels of $40 \mathrm{kDa} \mathrm{Nrf} 2$ in both fractions and provide free Nrf2 that can be involved in inducing antioxidant genes.

To further confirm that GST gene expression was regulated by the $\mathrm{Nrf2} \cdot \mathrm{MafG} / \mathrm{ARE}$ pathway, the translocation of MafG caused by freeze/thaw was also studied. Subcellular fractionation and western blotting demonstrated that MafG content increased strongly in the nucleus of skeletal muscle during freezing, whereas its level in the cytoplasm was strongly suppressed. This suggests that more MafG translocated into the nucleus from the cytoplasm during freezing. As a cofactor of $\mathrm{Nrf} 2$, the movement of MafG into nuclei could increase the level of Nrf2 MafG complex present and increase ARE binding activity.

In summary, my data demonstrate that some GST isoezymes were up-regulated at the protein level in multiple tissues during freeze/thaw in wood frogs. The GST Pi gene was also up-regulated at the transcriptional level in liver. Both Nrf2 and MafG were elevated during freeze/thaw and this suggests that the control of GST expression during freeze/thaw may be under the regulation of the $\mathrm{Nrf} 2 \cdot \mathrm{MafG}$ transcription factor regulating gene expression via the ARE. However, further work remains to be done to clarify the precise of mechanism of the Nrf2/ARE pathway and patterns of Nrf2 expression in wood frog tissues. 


\section{Chapter 4}

\section{General Discussion}




\section{Summary of the current study}

The wood frog, Rana sylvatica, is the model animal that has been most extensively used for studying vertebrate freezing survival (Storey and Storey, 2004). It is well known that this species has established multiple biochemical and physiological adaptations, many of which have been uncovered in our laboratory. The current study further explored the biochemical adaptations via modern molecular biology techniques. My thesis focused on two aspects: 1 . Anti-apoptotic defense to combat oxidative stress and/or anoxia/ischemia; 2. Antioxidant defense to deal with oxidative stress during freeze/thaw.

\subsection{Anti-apoptotic defense in the wood frog}

In this part, I identified and measured some proteins that are associated with proand anti-apoptotic mechanisms and the responses of these proteins to freeze-thaw stress in wood frog liver, kidney, skeletal muscle and skin. These proteins included some STAT family members that belong to the JAK-STAT signal transduction pathways as well as some Bcl-2 family members that belong to Bcl-2 signaling pathways. The data showed organ-specific response over the freeze/thaw process.

Much evidence from mammalian studies has shown a prominent role for Stat5 in promoting cell survival or anti-apoptosis (Battle and Frank, 2002). Hence, the elevated levels of phospho-Stat5 (Tyr694) in skeletal muscle, kidney, and skin during freeze/thaw support the idea that selected anti-apoptotic genes may be up-regulated under phosphoStat5 control in order to help organs to recover from metabolic insults or injuries caused by freezing. The similar responses of phospho-Stat5 (Tyr694) during aerobic recovery 
after anoxia exposure suggest that phospho-Stat5 is responding to a need for antiapoptosis defense during recovery after anoxia/ischemia and that it is this component of the freezing experience that is responsible for the thaw-associated rise in the amount of phosphorylated Stat5 in frog organs during thawing. The increased amount of this protein only in skin of dehydrated animals suggests that this response may be triggered by the dehydration of skin cells during freezing. However, the results of phospho-Stat5 (Tyr694) for liver suggest that the protein might have a different function that need further identify in this organ. For phospho-Stat1 (Tyr701), a similar response pattern to that seen for phospho-Stat5 (Tyr694) was observed in skeletal muscle, kidney and liver. However, Stat1 is considered to possess pro-apoptotic characteristics (Battle and Frank, 2002), which may suggest that some cell damage signals are generated during freeze/thaw. Whether the increase in phospho-Stat5 (Tyr694) during thawing has a function in overriding pro-apoptotic signaling from phospho-Statl (Tyr701) remains to be determined. A rise in anti-apoptotic signals during thawing may be one of the key mechanisms of natural freeze tolerance, allowing cells to recover from the stresses imposed by freezing by overriding signals that could otherwise lead to irreversible cell death. The increased levels of phospho-stat3 (Ser727) and the consequent activation of downstream gene(s) under Stat3 control that possesses anti-apoptotic properties may provide similar protection to liver during freeze/thaw.

Overall, my data indicate that STATs that possess a dual function (anti-apoptotic Stat5 and pro-apoptotic Stat1) are involved in anti-apoptosis in freeze tolerant wood frogs. Further research needs to be done, for example, to determine the relationship between tyrosine phosphorylated and unphosphorylated STAT1 and STAT5 and how they 
modulate expression of pro-apoptotic and anti-apoptotic regulatory genes to achieve net freezing survival of organs.

$\mathrm{Bcl}-2$, and Bcl-xL that is directly induced by STAT5, are important anti-apoptotic proteins in the $\mathrm{Bcl}-2$ protein family. Up-regulated Bcl-2 protein and more phosphorylated Bcl-2 (Ser70) could enhance survival of liver and skeletal muscle of wood frogs during freeze/thaw despite Bcl-xL being stable in these two organs. Although Bcl-2 was downregulated in kidney in freeze/thaw process, the up-regulation $\mathrm{Bcl}-\mathrm{xL}$ in this organ and the increased phosphorylation state of Bcl-2 might protect kidney cells from apoptosis during freeze/thaw. The data for the pro-apoptotic Bad protein and phospho-Bad (Ser112) demonstrate that freezing triggers apoptotic signals in liver and muscle cells, even though wood frogs are freeze tolerant animals. This was backed up by the data on DNA laddering that indicates that some damage is caused to frog liver by freeze/thaw. However, a net decrease in pro-apoptotic signaling from Bad suggests that no apoptosis or lower apoptosis was induced in kidney during freeze/thaw.

Taken together, the data demonstrate that pro-apoptotic signals are generated during freezing, but that wood frogs appear to have evolved a set of anti-apoptotic mechanisms to oppose freeze-induced cell death signals and allow freezing survival.

\subsection{Antioxidant defense in the wood frog}

Overall, the work presented in this section suggests that antioxidant defense may play a vital role in the survival of oxidative stress during freeze/thaw of wood frogs. The effects of freeze/thaw stress on some GSTs isozymes was characterized by analysis of protein expression as well as by mRNA expression of GST Pi. The data for GST Pi show 
that it is differentially regulated in frog tissues. In most tissues, including brain, gut, liver and skeletal muscle, the up-regulation of GST Pi during freeze/thaw probably maintains a high enzyme activity that allows for efficient detoxification of damage products that accumulate during freezing in organs. However, this GST isoform may be less important to antioxidant defense in kidney and heart since no change or reduced levels of GST Pi protein was seen in these two organs. An up-regulation of GST Pi mRNA levels was observed during freeze/thaw in liver; this was consistent with the enhanced expression of GST Pi protein and suggests that GST Pi has an important role in protecting liver cells from oxidative damage in freeze/thaw process. The data for GST M1/2 protein suggest that it is not involved in freeze/thaw antioxidant defense in frog organs except perhaps in gut.

The Nrf2/ARE pathway that regulates the expression of antioxidant enzymes was also assessed in this thesis. My data support the proposal that $\mathrm{Nrf2}$ and MafG transcriptionally activate GST gene expression in some frog tissues, but it cannot exclude other mechanisms of transcriptional regulation that may be involved in gut tissue. In conclusion, some GST isozymes contribute an effective function to protect frog cells from oxidative stress caused by freeze/thaw. The Nrf2/ARE pathway is clearly involved in regulating antioxidant defense during freeze/thaw but further study is still needed to fully clarify the regulatory mechanisms.

\section{Future work and new directions}

\subsection{Phosphorylation of Bad: PI3/AKTpathway or MAPK/ERK pathway}

It is well known that reversible phosphorylation of Bad plays a vital role to 
initiate or resist apoptosis by cells. Phosphorylated Bad is sequestered in its inactive form in the cytosol by 14-3-3 protein, while dephosphorylated Bad is targeted to the mitochondria and induces apoptosis by binding $\mathrm{Bcl}-\mathrm{xL}$ and $\mathrm{Bcl}-2$ (Chiang et al., 2003). Therefore, it is necessary to understand the mechanisms that regulate Bad phosphorylation in order to determine how to promote phosphorylation of $\mathrm{Bad}$ as a possible mechanism of inhibiting apoptosis. When apoptosis occurs in mammalian cells, cytochrome $c$ is released from mitochondria and binds to the apoptotic proteaseactivating factor (Apaf-1) to activate it. Apaf-1 then binds to, cleaves and activates the cysteine protease, caspase- 9 which subsequently initiates a caspase cascade culminating in the activation of the executioner caspases (Thornberry et al., 1998). The initiator caspases (such as caspase-9) activate through cleavage of downstream effector caspases (such as caspases 3 and 7), which then cleave a variety of cellular substrates that are critical to the generation of the apoptotic phenotype. These are downstream events of apoptosis. Currently, there are two major kinases that are known to be involved in Bad phosphorylation (Gross et al., 1999; Bae et al., 2001; Datta et al., 1999; Song et al., 2005); one is phosphatidylinositol-3-kinase/protein kinase B (PI-3/Akt, also called $\mathrm{Akt} / \mathrm{PKB}, \mathrm{Akt})$ and the other one is mitogen-activated protein kinase/extracellular signalregulated protein kinase (MAPK/ERK). Akt/PKB protein kinase, a serine/threonine kinase, belongs to the cAMP-dependent kinase A/protein kinase G/protein kinase $\mathrm{C}$ superfamily of protein kinases that share structural homology within their catalytic domain and have the similar mechanism of activation (Song et al., 2005).

Over the past decade, Akt has emerged as a central player in the signal transduction pathways that are activated in response to growth factors or insulin and is 
considered to contribute to several cellular functions including nutrient metabolism, cell growth, transcriptional regulation and cell survival (Brazil et al., 2001). Experiments have demonstrated that Akt itself is a phosphoprotein, and that phosphorylation is required for Akt activity both in vivo and in vitro (Datta et al., 1999). Recent studies have demonstrated that Akt regulates apoptosis at multiple sites, and has identified direct Akt targets including Bad and caspase-9 (Datta et al., 1999). The Bad Ser-112 and Ser-136 phosphorylation sites play a vital role in regulating Bad function. These sites also both lie within consensus sequences that correspond to the Akt phosphorylation site, and Akt was found to potently phosphorylate Bad in vitro (Datta et al., 1997; Del Peso et al. 1997); Akt preferentially phosphorylates Bad at Ser-136. Blume-Jensen et al. (1998) revealed that Akt and Bad were colocalized within cells via indirect immunofluorescence microscopy. This provides further evidence for a direct Akt-Bad interaction. The data from Cardone et al. (1998) also suggests that Akt promotes survival through the inactivation of caspase- 9 downstream of cytochrome $c$ release, although it is not clear how phosphorylation of caspase-9 results in its inactivation.

Based on the discussion above, Akt could be considered to be an important regulator of Bad and caspase-9 in wood frog cells. However, other studies demonstrate that MAPK/ERK also phosphorylates Bad (Chen et al., 2005; Scheid and Duronio, 1998; Scheid et al., 1999; Harada et al., 1999). Bad phosphorylation on Ser112 was detected in frog tissues and phosphorylation on this site is known to occur in a MAPK/ERKdependent manner; indeed, Serine 112 phosphorylation was shown to be absolutely required for dissociation of $\mathrm{Bad}$ from $\mathrm{Bcl}-\mathrm{xL}$ (Scheid et al., 1999). Hence, further experiments are needed to confirm which kinase (or both them) is involved in Bad 
phosphorylation in wood frog cells. In addition, dephosphorylation of Bad also plays a gatekeeper role for Bad-mediated apoptosis; this is another vital and meaningful project in this field.

\subsection{Nrf2 and STATs: Electrophoretic mobility shift assay (EMSA)}

The data for GSTs, Nrf2 and MafG raised the possibility that GSTs were regulated via the Nrf2/ARE pathway in response to oxidative stress during freeze/thaw. To determine whether binding of $\mathrm{Nrf} \cdot \mathrm{MafG}$ to the ARE increases during freezing, further analyses of the binding ability in frozen and thawed frogs versus control frogs will be necessary. The EMSA technique will be needed for this; EMSA analysis is based on the observation that protein:DNA complexes migrate more slowly than free DNA molecules when subjected to non-denaturing polyacrylamide or agarose gel electrophoresis. Because the rate of DNA migration is shifted or retarded upon protein binding, the assay is also referred to as a gel shift or gel retardation assay. In addition, as transcriptional factors, following phosphorylation, dissociating from the receptor, dimerizing in the cytoplasm, phospho-STATs transolcate to the nucleus, where they bind to specific sequences within the promoters of target genes. So the binding could also be confirmed by EMSA.

\subsection{Complementary work to the current research}

In the anti-apoptosis work, I examined the protein levels of some Bcl-2 family proteins in liver, skeletal muscle and kidney. However, brain and heart are known to be very susceptible to oxidative stress due to ischemia/reperfusion in other systems (Love, 
2003, Kumar and Jugdutt, 2003). Predictably these tissues might also be the most susceptible organs in wood frogs to ischemia/reperfusion damage during freeze/thaw. Hence, further studies should also analyze the anti-apoptotic mechanisms in these two organs. Furthermore, the transcriptional level of $\mathrm{Bad}$ and $\mathrm{Bcl}-2$ should be analyzed via PCR in order to determine whether these proteins are regulated at transcriptional or translational levels under freeze/thaw conditions. As for antioxidant research, future work could determine the full length cDNA and protein sequence of wood frog GST Pi using 5' and 3' RACE PCR. Hence, we can know whether key regulatory elements of the protein are similar or different from the protein structure in other animals. Analysis of the involvement of other antioxidant enzymes and proteins in freeze/thaw protection is also needed including measurement of both protein and mRNA levels of antioxidant proteins including HO1, SOD, NQO1 and thioredoxin in wood frog tissues. 


\section{References}

Armstrong RN. (1997) Structure, catalytic mechanism, and evolution of the glutathione transferases. Chem. Res. Toxicol.10: 2-18.

Bae J, Hsu SY, Leo CP, Zell K, Hsueh AJW. (2001) Under-phosphorylated BAD interacts with diverse anti-apoptotic Bcl-2 family proteins to regulate apoptosis. Apoptosis 6: 319-330.

Battle TE, Frank DA. (2002) The role of STATs in apoptosis. Curr. Mol. Med. 2: 381392.

Behler JL, King FW. (1979) The Audubon Society Field Guide to North American Reptiles and Amphibians, Alfred A. Knopf, New York.

Bentley DL, Groudine M. (1996) A block to elongation is largely responsible for decreased transcription of c-myc in differentiated HL 60 cells. Nature 321: 702706.

Blank V, Kim MJ, Andrews NC. (1997) Human MafG is a functional partner for p45 NFE2 in activating globin gene expression. Blood, 89(11): 3925-3935.

Blokhnia O, Virolainen, E, Fagerstedt K. (2003) Antioxidants, oxidative damage and oxygen deprivation stress: a review. Ann. Bot. 91: 179-194.

Blume-Jensen PR, Janknecht R, Hunter T. (1998) The kit receptor promotes cell survival via activation of PI-s-kinase and subsequent Akt-mediated phosphorylation of Bad in Ser136. Curr. Biol. 8: 779-782.

Bolli, R, Dawn B, Xuan YT. (2003) Role of the JAK-STAT pathway in protection against myocardial ischemia/reperfusion injury. Trends Cardiovasc Med.13 (2): 72-79.

Brazil DP, Hemmings BA. (2001) Ten years of protein kinase B signaling: a hard Akt to 
follow. Trends Biochem. Sci. 26: 657-664.

Bromberg J, Darnell JE. (2000) The role of STATs in transcriptional control and their impact on cellular function. Oncogene 19 (21): 2468-2473.

Buttner R, Mora LB, Jove R. (2002) Activated STAT signaling in human tumors provides novel molecular targets for therapeutic intervention. Clin. Cancer Res. 8: $945-$ 954.

Cai Q, Storey KB. (1997a) Freezing-induced genes in wood frog (Rana sylvatica): fibrinogen upregulation by freezing and dehydration. Am. J. Physiol. 272: 14801492.

Cai Q, Storey KB. (1997b) Upregulation of a novel gene by freezing exposure in the freeze-tolerant wood frog (Rana sylvatica). Gene 198: 305-312.

Cai Q, Greenway SC, Storey KB. (1997) Differential regulation of the mitochondrial ADP/ATP translocase gene in wood frogs under freezing stress. Biochem. Biophys. Acta 1343: 69-78.

Cardone MH, Roy N, Stennicke HR, Salvasen GS, Franke TF, Stanbridge E, Frisch S, Reed JC. (1998) Regulation of cell death protease caspase-9 by phosphorylation. Science 282: 1318-1321.

Chanas SA, Jiang Q, McMahon M, McWalter GK, McLellan LI, Elcombe CR, Henderson CJ, Wolf CR, Moffat GJ, Itoh K, Yamamoto M, Hayes JD (2002) Loss of the Nrf2 transcription factor causes a marked reduction in constitutive and inducible expression of the glutathione S-transferase Gsta1, Gsta2, Gstm1, Gstm2, Gstm3 and Gstm4 genes in the livers of male and female mice. Biochem. J. 365: 405-416. 
Chang BS, Minn AJ, Muchmore SW, Fesik SW, Thompson CB (1997) Identification of novel regulatory domain in Bcl-xL and Bcl-2. EMBOJ. 16(5): 968-977.

Chen XQ, Lau LT, Fung YW, Yu CH. (2005) Inactivation of Bad by site-specific phosphorylation: the checkpoint for ischemic astrocytes to initiate or resist apoptosis. J. Neurosci. Res. 79: 798-808.

Chiang CW, Kanies C, Kim KW, Fang WB, Parkhurst C, Xie M, Henry T, Yang E (2003) Protein phosphatase 2A dephosphorylation of phosphoserine 112 plays the gatekeeper role for BAD-mediated apoptosis. Mol. Cell. Biol. 23(18): 6350-6362.

Churchill TA, Storey KB. (1993) Dehydration tolerance in wood frogs: a new perspective on the development of amphibian freeze tolerance. Am. J. Physiol. 265: R1324R1332.

Darnell, J. E. (1982) Variety in the level of gene control in eukaryotic cells. Nature 297: $365-371$.

Datta SR, Brunet A, Greenberg ME. (1999) Cellular survival: a play in three Akts. Genes Dev. 13: 2905-2927.

Datta SR, Dudek H, Tao X, Masters S, Fu H, Gotoh Y, Greenberg ME. (1997) Akt phosphorylation of $\mathrm{BAD}$ couples survival signals to the cell-intrinsic death machinery. Cell 91: 231-241.

De Croos JNAD. (2003) Gene and protein regulation in liver of the freeze tolerant wood frog, Rana sylvatica. Ph.D Thesis, Carleton University.

Del Peso L, Gonzalez-Garcia M, Page C, Herrera R, Nunez G. (1997) Interleukin-3induced phosphorylation of BAD through the protein kinase Akt. Science 278: 687-689. 
Deng X, Xiao L, Lang W, Gao F, Ruvolo P, May WS (2001) Novel role for JNK as a stress-activated Bcl2 kinase. J. Biol. Chem. 276 (26): 23681-23688.

Dudley AC, Thomas, D, Best J, Jenkins A. (2004) The STATs in cell stress-type responses, Cell Commun. Signal. 2: 8 .

Efting F, Rensing B, Wigman J, Pannekoek WJ, Liu WM, Cramer MJ, Lips DJ, Doevendans P. (2004) Role of apoptosis in reperfusion injury, Cardiovasc. Res .61: 414-426.

Fiers W. Beyaert W, Declercq W, Vandenabeele P. (1999) More than one way to die: apoptosis, necrosis and reactive oxygen damage, Oncogene 18: 7719-7730.

Figueroa B, Sauerwald TM, Mastrangelo AJ, Hardwick JM, Betenbaugh MJ (2001) Comparison of Bcl-2 to a Bcl-2 deletion mutant for mammalian cells exposed to culture insults. Biotechnol. Bioeng. 73(3): 211-222.

Finucane DM, Bossy-Wetzel E, Waterhouse NJ, Cotter TG, Green DR. (1999) Baxinduced caspase activation and apoptosis via cytochrome $c$ release from mitochondrial is inhibitable by Bcl-xL. J. Biol. Chem. 274: 2225-2233.

Gesbert F, Griffin JD. (2000) Bcr/Abl activates transcription of the Bcl-X gene through STAT5. Blood 96 (6): 2269-2276.

Green DR, Reed JC. (1998) Mitochondria and apoptosis. Science 281:1309-1312.

Gross A, Mcdonnell JM, Korsmeyer SJ (1999) Bcl-2 family members and the mitochondria in apoptosis. Gene Devel. 13: 1899-1911.

Harada H, Becknell B, Wilm M, et al. (1999) Phosphorylation and inactivation of BAD by mitochondria-anchored protein kinase A. Mol. Cell 3: 413-422.

Haunstetter A, Izumo S. (1998) Apoptosis: basic mechanisms and implications for 
cardiovascular disease. Circ Res. 82: 1111-1129.

Hayes JD, Mclellan LI. (1999) Glutathione and glutathione-dependent enzymes represent a co-ordinately regulated defence against oxidative stress. Free Radic Res. 31(4): 273-300.

Hayes JD, Pulford DJ. (1995) The glutathione S-transferase supergene family: regulation of GST and the contribution of the isoenzymes to cancer chemoprotection and drug resistance. Crit. Rev. Biochem. Mol. Biol. 30(6): 445-600.

Hayes JD, Strange RC. (1995) Potential contribution of the glutathione S-transferases supergene family to resistance to oxidative stress. Free Radic. Res. 22(3): 193207.

Hermes-Lima M, Storey JM, Storey KB. (2001) Antioxidant defenses and animal adaptation to oxygen availability during environmental stress. In: Cell and Molecular Responses to Stress (Storey KB, Storey JM, eds.), Vol. 2: Protein Adaptations and Signal Transduction. Elsevier Press, Amsterdam, 263-287.

Holden CP, Storey KB. (1997) Second messenger and cAMP-dependent protein kinase responses to dehydration and anoxia stresses in frogs. J. Comp. Physiol. B 167: 305-312.

Horiuchi M, Hayashida W, Kambe T, Yamada T, Dzau VJ. (1997) Angiotensin types receptor dephosphorylates bcl-2 by activating mitogen-activated protein kinase phosphatase-1 and induces apoptosis. J. Biol. Chem. 272(30): 19022-19026.

Hunt JV, Bottoms MA, Mitchinson MJ (1993) Oxidative alterations in the experimental glycation model of diabetes mellitus are due to protein-glucose adduct formation. Biochem. J. 291: 529-535. 
Itoh K, Wakabayashi N, Katoh Y, Ishii T, Igarashi K, Engel JD, Yamamoto M. (1999) Keap1 represses nuclear activation of antioxidant responsive elements by $\mathrm{Nrf} 2$ through binding to the amino-terminal Neh2 domain. Genes Dev. 13 (1): 76-86.

Jianrong L, Christopher AB, Sufang Y, Young-Myeong K, Billiar TR. (1999) Nitric oxide suppresses apoptosis via interrupting caspase activation and mitochondrial dysfunction in cultured hepatocytes, J. Biol. Chem. 274: 17325-17333.

Joanisse DR, Storey KB. (1996) Oxidative damage and antioxidant in Rana sylvatica, the freeze-tolerant wood frog. Am. J. Physiol. 271: 545-553.

Kang KW, Lee SJ, Park JW, Kim SG. (2002) Phosphatidylinositol 3-kinase regulates nuclear translocation of NF-E2-related factor 2 through actin rearrangment in response to oxidative stress. Mol. Pharmacol. 62 (5): 1001-1010.

Kaplan DH, Shankaran V, Dighe AS, Stockert E, Aguet M, Old LJ, Schreiber RD. (1998) Demonstration of an interferon-dependent tumor surveillance system in immunocompetent mice. Immunology 95(13): 7556-7561.

Kazi S, Ellis EM. (2002) Expression of rat liver glutathione-S-transferase GSTA5 in cell lines provides increased resistance to alkylating agents and toxic aldehydes. Chem. Biol. Interact. 140(2): 121-135.

Kerr JFR, Wyllie AH, Currie, AR. (1972) Apoptosis: a basic biological phenomenon with wide-ranging implications in tissue kinetics. Br. J. Cancer. 26: 239-257.

Kumar D, Jugdutt B. (2003) Apoptosis and oxidant in the heart. J. Lab. Clin Med. 142 (5): 288-297.

Lee CK, Smith E, Gimeno R, Gertner R, Levy DE. (2000) STAT1 affects lymphocyte survival and proliferation partially independent of its role downstream of IFN- $\gamma . J$. 
Immunol. 164: 1286-1292.

Leonard WL, O'Shea JJ. (1998) JAKs and Stats: biological implications. Annu. Rev. Immunol. 16: 293-322.

Li ZH. (2004) Gene expression supporting freeze tolerance in the wood frog, Rana sylvatica. MSc Thesis, Carleton University.

Love S. (2003) Apoptosis and brain ischaemia. Neuropsychopharmacol Biol. Psychiatry 27 (2): 267-282.

MacLellan WR, Schneider MD. (1997) Death by design. Circ Res, 81: 137-144.

Mastrangelo AJ, Hardwick JM, Bex F, Betenbaugh MJ. (2000) Part I. Bcl-2 and Bcl-xL limit apoptosis upon infection with alphavirus vectors. Biotechnol. Bioeng. 67(5): 544-554.

Mastrangelo AJ, Hardwick JM, Zou S, Betenbaugh MJ. (2000) Part II. Overexpression of bcl-2 families enhance survival of mammalian cells in response to various culture insults. Biotechnol. Bioeng. 67(5): 555-564.

Mazur P. (1984) Freezing of living cells: mechanisms and implications. Am. J. Physiol. 247: $125-142$.

McNally JD. (2002) Response to freeze exposure by the wood frog Rana sylvatica: investigating the freeze induced changes in transcription and translation patterns in heart and liver. Ph.D Thesis, Carleton University.

Motohashi H, Yamamoto M. (2004) Nrf2-Keap1 defines a physiologically important stress response mechanism. Trends Mol. Med. 10(11): 549-557.

Murzin AG, Brenner SA, Hubbard T, Chothia C. (1995) SCOP: a structural classification of proteins database for the investigation of sequences and structures. J. Mol. Biol. 
247: $536-540$.

Nagata S (2000) Apoptotic DNA fragmentation. Exp. Cell Res. 256(1): 12-18.

Nguyen T, Sherratt PJ, Pickett CB. (2003) Regulatory mechanisms controlling gene expression mediated by the antioxidant response element. Annu. Rev. Pharmacol. Toxicol. 43: 233-260.

Nomura K, Imai H, Koumura T, Arai M, Nakagawa Y. (1999) Mitochondrial phospholipid hydroperoxide glutathione peroxidase suppresses apoptosis mediated by a mitochondrial death pathway. J. Biol. Chem. 274: 29294-29302.

Rubinsky B, Wong STS, Hong JS, Gilbert J, Roos M, Storey KB. ${ }^{1} \mathrm{H}$ Magnetic resonance imaging of freezing and thawing in freeze-tolerant frogs. Am. J. Physiol. 266: $1771-1777$.

Ruvolo PP, Clark W, Mumby M, Gao F, May WS (2002) A functional role for the B56 $\alpha$ subunit of protein phosphatase $2 \mathrm{~A}$ in ceramide-mediated regulation of $\mathrm{Bcl} 2$ phosphorylation status and function. J. Biol. Chem. 277(25): 22847-22852.

Ruvolo PP, Deng X, Carr BK, May WS. (1999) A function role for mitochondrial protein kinase $\mathrm{C} \alpha$ in bcl-2 phosphorylation and suppression of apoptosis. J. Biol. Chem. 273(29): $25436-25442$.

Sahni M, Raz R, Coffin JD, Levy D, Basilico C. (2001) STAT1 mediates the increased apoptosis and reduced chondrocyte proliferation in mice overexpressing FGF2. Development 128: 2119-2129.

Saikumar P, Venkatachalam MA. (2003) Role of apoptosis in hypoxic/ischemic damage in the kidney. Semin. Nephrol. 23(6): 511-521.

Scheid MP, Duronio V. (1998) Dissociation of cytokine-induced phosphorylation of Bad and activation of PKB/akt: involvement of MEK upstream of $\mathrm{Bad}$ 
phosphorylation. Proc. Natl. Acad. Sci. USA. 95(13): 7439-7444.

Scheid MP, Schubert KM, Duronio V. (1999) Regulation of Bad phosphorylation and association with Bcl-x(L) by the MAPK/Rrk kinase. J Biol Chem 274: 3110831113.

Sherratt PJ, Hayes JD. (2002) Glutathione S-transferases. Enzyme systems that metabolize drugs and other xenobiotics. (Loannides C, ed.) John Wiley \& Sons, Ltd.

Silva M, Benito A, Sanz C, Prosper F, Ekhterae D, Nunez G, Fernandez-Luna JL. (1999) Erythropoietin can induce the expression of $\mathrm{Bcl}-\mathrm{X}_{\mathrm{L}}$ through Stat5 in Erythropoietin-dependent progenitor cell lines. J. Biol. Chem. 274 (32): 2216522169.

Simon AR, Rai U, Fanburg BL, Cochran BH. (1998) Activation of the JAK-STAT pathway by reactive oxygen species. Am. J. Physiol. 275 (6): C1640-C1652.

Singh RP, Emery AN, Al-Rubeai M. (1996) Enhancement of survivability of mammalian cells by overexpression of the apoptosis-suppressor gene bcl-2. Biotechnol. Bioeng. 52: 166-175.

Smith ML, Fornace AJ (1996) Mammalian DNA damage-inducible genes associated with growth arrest and apoptosis. Mutat. Res. 340: 109-124.

Socolovsky M, Fallon AE, Wang S, Brugnara C, Lodish HF. (1999) Fetal anemia and apoptosis of red cell progenitors in Stat5a $\mathrm{a}^{-1-} 5 \mathrm{~b}^{-1-}$ Mice: a direct role for Stat5 in Bcl- $\mathrm{X}_{\mathrm{L}}$ induction. Cell 98:181-191.

Song G, Ouyang G, Bao S. (2005) The activation of Akt/PKB signaling pathway and cell survival. J. Cell Mol. Med. 9 (1): 59-71. 
Stephanou A, Latchman DS. (2003) STAT-1: a novel regulator of apoptosis. Int. J. Exp. Pathol. 84 (6): 239-44.

Storey KB, Storey JM. (1993) Cellular adaptations for freezing survival by amphibians and reptiles. In: Advances in low temperature biology (Steponkus, PL, ed.) vol.2, 101-129, London: JAI Press.

Storey KB, Storey JM. (1984) Biochemical adaptation for freezing tolerance in the wood frog, Rana sylvatica. J. Comp. Physiol. B 155: 29-36.

Storey KB. (1987a) Organ-specific metabolism during freezing and thawing in a freezetolerant wood frog. J. Comp. Physiol. B 157: 373-380.

Storey KB, Storey JM (2004) Physiology, biochemistry and molecular biology of vertebrate freeze tolerance: the wood frog. In: Life in the Frozen State (Benson E, Fuller B, Lane N, eds.) CRC Press, Boca Raton, pp.243-274.

Takahashi A, Masuda A, Sun M, Centonze VE, Herman B. (2004) Oxidative stressinduced apoptosis is associated with alterations in mitochondrial caspase activity and Bcl-2-dependent alterations in mitochondrial $\mathrm{pH}\left(\mathrm{pH}_{\mathrm{m}}\right), \quad$ Brain Res. Bull. 62: 497-504.

Thornberry NA, Lazebnik Y. (1998) Caspases: enemies within. Science 281: 312-316.

Vaux DL, Korsmeyer SJ. (1999) Cell death in development. Cell 96: 245-254.

White D, Storey KB. (1999) Freeze-induced alterations of translatable mRNA populations in wood frog organs. Cryobiology 38, 353-362.

Wu SB. (1999) Differential gene expression under environmental stress in the freeze tolerant wood frog, Rana sylvatica. Ph.D Thesis, Carleton University.

Xuan YT, Guo Y, Han H, Zhu Y, Bolli R. (2001) An essential role of the JAK-STAT 
pathway in ischemic preconditioning. Proc. Natl. Acad. Sci. USA 98(16): 90509055.

Yan B, Zemskova M, Holder S, Chin V, Kraft A, PJ Koskinen, Lilly M (2003) The PIM2 kinase phosphorylates $\mathrm{BAD}$ on serine 112 and reverses $\mathrm{BAD}$-induced cell death. J. Biol. Chem. 278(46): 45358-45367.

Yang E, Zha J, Jockel J, Boise LH, Thompson CB, Korsmeyer SJ (1995) Bad, a heterodimeric partner of $\mathrm{Bcl}-\mathrm{xL}$ and $\mathrm{Bcl}-2$, displaces Bax and promotes cell death. Cell, 80: 285-291.

Zamzami N, Brenner C, Marzo I, Susin SA, Kroemer G. (1998) Subcellular and submitochondrial mode of action of Bcl-2 like oncoproteins. Oncogene 16: $2265-2282$

Zha J, Harada H, Yang E, Jockel J, Korsmeyer SJ (1996) Serine phosphorylation of death agonist $\mathrm{BAD}$ in response to survival factor results in binding to 14-3-3 not Bcl$\mathrm{x}(\mathrm{L})$. Cell 87: 619-628.

Zhao ZQ. (2004) Oxidative stress-elicited myocardial apoptosis during reperfusion, Curr. Opin. Pharmacol. 4: 159-165. 